\title{
PENGARUH IMPLEMENTASI KEBIJAKAN TERHADAP KINERJA PEGAWAI DI KANTOR SATUAN POLISI PAMONG PRAJA KABUPATEN SUBANG
}

(Studi Implementasi Mengenai Peraturan Daerah Kab. Subang No. 13 Tahun 2006 Tentang Ketertiban, Kebersihan dan Keindahan)

\section{TESIS}

Diajukan Untuk Memenuhi Syarat Ujian Guna Memperoleh Gelar Magister Sains (M.Si.) Pada Konsentrasi Kebijakan Publik Program Magister Ilmu AdministrasiProgram Pasca Sarjana Universitas Pasundan Bandung

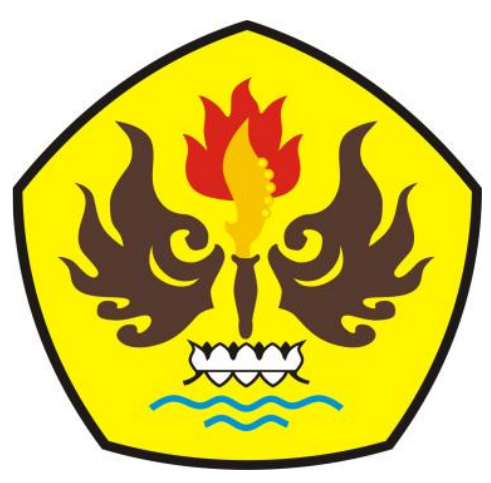

PROGRAM MAGISTER ILMU ADMINISTRASI PROGRAM PASCASARJANA UNIVERSITAS PASUNDAN 


\begin{abstract}
ABSTRAK
Masalah pokok dalam penelitian ini adalah kinerja pegawai yang rendah di Kantor Satuan Polisi Pamong Praja Kabupaten Subang. Diduga hal ini disebabkan oleh faktor implementasi kebijakan yang belum dilaksanakan secara optimal. Metode penelitian yang digunakan adalah deskriptif analisis, yaitu dengan mendeskripsikan masing-masing variabel serta menguji kedua variabel dengan pendekatan kuantitatif (statistik) yang selanjutnya dianalisis dan dibandingkan dengan teori serta masalah yang ada untuk diambil kesimpulannya kemudian.

Hasil penelitian yang didasarkan oleh hipotesis secara parsial menyebutkan bahwa variabel implementasi kebijakan dapat dideteksi dari besarnya pengaruh masing-masing faktor yang terdiri atas implementasi kebijakan (X) yang dibagi menjadi enam faktor yaitu Standar dan Sasaran Kebijakan (X1) sebesar 21,3 \%, Sumber daya (X2) sebesar 14,1 \%, Karakteristik organisasi pelaksana (X3) sebesar 12,8 \%, Komunikasi antar organisasi pelaksana dan kegiatan-kegiatan pelaksanaan (X4) sebesar $6.3 \%$, Sikap para pelaksana (X5) sebesar 9,2 \%, Lingkungan sosial ekonomi dan politik (X6) sebesar 7,3\% yang digunakan terhadap kinerja pegawai pada Kantor Satuan Polisi Pamong Praja Kabupaten Subang. Sedangkan pengaruh secara simultan dapat dilihat dari optimalisasi pengaruh faktor implementasi kebijakan secara keseluruhan (bersama-sama). Besaran pengaruh implementasi kebijakan sebesar 71,2\% sedangkan faktor lain yang tidak diteliti (epsilon) tetapi mempengaruhi terhadap kinerja pegawai sebesar $28,8 \%$

Kesimpulan dalam penelitian ini adalah implementasi kebijakan merupakan peranan penting untuk mempermudahkan para pegawai didalam melakukan kinerja dari setiap pelaksanaan suatu implementasi kebijakan demi tercapainya suatu ketertiban, kebersihan, dan keindahan tatanan masyarakat.
\end{abstract}




\begin{abstract}
The basic problem in this research is that low performance of employees in the Office of Civil Service Police Unit Subang district. The Aformantion caused by factors policy implementation has not been implemented optimally.

The research method used is descriptive analysis, namely by describing each variable and tested both variables with a quantitative approach (statistical) which was subsequently analyzed and compared with existing theories and issues to be taken later conclusions.

The results are based by hypothesis states that partial implementation of the policy variables can be detected from the level of influence of each factor consisting of policy implementation $(X)$ is divided into six factors: Standards and Objectives Policies (X1) of 21.3\%, Sources power (X2) equal to $14.1 \%$, characteristic of the implementing organizations (X3) amounted to $12.8 \%$, communication between the implementing organization and implementation activities (X4) of $6.3 \%$, attitude of the implementers (X5) amounted to 9.2\%, socio-economic and political environment (X6) of $7.3 \%$ used the performance of employees in the Office of Civil Service Police Unit Subang district. While the effect can be seen from the simultaneous optimization of factors influence the overall policy implementation (shared). Magnitude of the effect of policy implementation by $71.2 \%$ while other factors not examined (epsilon) but affects the performance of employees amounted to $28.8 \%$

The conclusion of this research is the role of policy implementation is essential to facilitate the employees, in making the performance of each implementation of a policy implementation for the achievement of an order, cleanliness and beauty of the fabric of society.
\end{abstract}




\section{BAB I}

\section{PENDAHULUAN}

\subsection{Latar Belakang Penelitian}

Proses reformasi terus menggelinding, sejalan dengan perubahan dan tuntutan kehidupan masyarakat yang semakin kuat dan perlunya dilakukan penataan berbagai struktur tingkatan institusi yang ada pada setiap organisasi. Terjadinya perubahan politik secara cepat yang berdampak pada ambruknya tatanan ekonomi dan sosial perlu segera dibangun kembali pranata baru yang disesuaikan dengan tuntutan zaman. Dalam pembangunan pranata baru itu, perananan administrasi sangat besar yang telah ditetapkan berbagai kebijakan oleh para elite politik di saat terbentuknya pemerintahan Indonesia yang kuat.

Kepentingan publik merupakan persamaan kebutuhan yang dimiliki oleh setiap anggota masyarakat yang pada umumnya ingin dicapai. Ditinjau dari segi hubungan masyarakat, setiap organisasi baik berupa instansi maupun swasta harus ikut menjaga kepentingan publik. Bila diperhatikan dewasa ini telah dirasakan di mana-mana, bahwa tingkat kesadaran politik masyarakat cenderung semakin meningkat. Hal ini dapat dilihat dari semakin banyaknya orang terlibat dalam partisipasi politik.

Kepentingan publik itu mau tidak mau akan menyangkut pada soal kepentingan pribadi sebagai sumber utama adanya kepentingan umum. Sebab kepentingan umum merupakan suatu bentuk himpunan kepentingan pribadi yang 
sama dari kelompok orang atau masyarakat, walaupun tidak berarti bahwa setiap kepentingan yang sama dari sekelompok masyarakat otomatis menjadi kepentingan publik. Secara singkat dapat dinyatakan bahwa kepentingan umum atau publik adalah himpunan dari kepentingan pribadi yang telah disublimasikan dan tidak bertentangan dengan norma masyarakat serta aturan yang berlaku.

Seiring dengan perubahan zaman yang ke arah sana semakin berkembang tatanan pemerintah menuju kepemerintahan yang lebih baik, untuk meningkatkan kepentingan publik demi terselengaranya kesejahteraan masyarakat dan kemajuan bangsa Indonesia. Untuk menuju ke arah itu sistem administrasi Negara berkembang terus sesuai dengan faktor lingkungan yang mempengaruhi.

Tatanan pemerintah saat ini mulai dirasakan dengan adanya otonomi daerah di seluruh provinsi atau daerah yang berada di ruang lingkup kesatuan bangsa dan negara Indonesia. Kewenangan kebijakan dan peraturan dimulai dengan adanya UU No. 32 Tahun 2004 tentang otonomi daerah, saat ini sudah diterapkan oleh setiap pemerintah yang berada di daerah untuk mengembangkan, menata, memajukan daerah-daerahnya. Perkembangan sistem pemerintahan untuk menata daerahnya sering kali dipengaruhi oleh aspek kegiatan organisasi terhadap kebutuhan masyarakat untuk memenuhi kehidupannya. Misalkan Kabupaten Subang untuk menuju kota yang berkembang menjadi kota yang bersih, bermartabat, indah, aman, dan tertib harus mengeluarkan suatu kebijakan publik demi kepentingan publik. Untuk menjadikan tatanan Kabupaten Subang menjadi lebih bersih, bermartabat, indah, aman dan tertib, Pemerintah Daerah Kabupaten 
Subang mengeluarkan kebijakan publik dalam Peraturan Daerah Kabupaten Subang Nomor 13 Tahun 2006 Tentang Ketertiban, Kebersihan dan Keindahan.

Peraturan Daerah Kabupaten Subang Nomor 13 Tahun 2006 Tentang Ketertiban, Kebersihan dan Keindahan, merupakan suatu kebijakan publik yang harus dipatuhi masyarakat dan ditegakkan oleh suatu organisasi yaitu Satuan Polisi Pamong Praja untuk melaksanakan dan menegakan peraturan daerah tersebut. Proses pelaksanaan implementasi kebijakan dalam penegakan peraturan daerah itu akan memberikan suatu interaksi timbal balik antara kinerja pegawai Satuan Polisi Pamong Praja dengan kelompok sasarannya. Kinerja pegawai Satuan Polisi Pamong Praja mempunyai peran sangat penting kepada masyarakat yang mangganggu ketertiban, kebersihan dan keindahan kota, maka dari itu kinerja dari satuan polisi pamong praja dalam penegakan peraturan daerah harus ditingkatan yang sesuai dengan norma dan moral yang berlaku pada setiap tatanan sosial masyarakat. Mengingat pentingnya kebijakan publik itu untuk menuju pemerintah daerah yang tertib, bersih, indah, kinerja pegawai satuan polisi pamong di Kabupaten Subang dituntut untuk memberikan suatu dampak positif dalam penegakan setiap peraturan daerah yang sudah ditetapkan sebelumnya.

Peranan kinerja pegawai satuan polisi pamong praja yang ada di Kabupaten Subang sangat penting dalam penegakan peraturan daerah. Namun sangat disayangkan kinerja pegawai Satuan Polisi Pamong Praja mengalami kendala dan hambatan sering terhimpit dalam berbagai macam permasalahan yang ditimbulkan akibat dari pelaksanaan implementasi kebijakan terutama antara 
kebutuhan hidup masyarakat untuk memenunhi kebutuhannya, tujuan individual dan tujuan organisasi itu sendiri.

Kinerja pegawai Satuan Polisi Pamong Praja itu harus siap untuk menerima segala resiko dan tanggungjawab yang dihadapinya dalam pelaksanaan implementasi kebijakan peraturan pemerintahan daerah tersebut. Kinerja pegawai yang dimaksud berkaitan dengan hasil-hasil kerja agar pekerjaan yang dilakukan dapat dicapai dengan optimal dan memenuhi standar yang telah ditetapkan organisasi.

Peranan kinerja pegawai merupakan salah satu alat untuk mengukur keberhasilan yang diperoleh organisasi dalam pencapaian tujuannya. Suatu kinerja yang diberlakukan oleh suatu organisasi bersandar pada aturan yang diterapkan oleh instansi tersebut, sehingga dalam realisasinya dapat dilakukan oleh anggota organisasi atau pegawai akan mampu untuk bekerja secara semaksimal serta menghidari dari penilaian subjektif yang tidak semestinya. Kinerja pegawai akan berjalan dengan baik atau organisasi itu berjalan lancar apa bila implementasi kebijakan itu tepat kearah sasaran kelompok masyarakatnya.

Berdasarkan hasil penelitian bahwa diketahui kinerja pegawai di Satuan Polisi Pamong Praja di kota Subang masih rendah, dengan indikator sebagai berikut :

1. Kualitas pegawai Satuan Polisi Pamong Praja belum sepenuhnya dilaksanakan. Terbukti penertiban pedagang kaki lima seharusnya satu hari dapat ditertibkan ternyata baru bisa ditertibkan selama dua hari. 
2. Tingkat kuantitas pegawai Satuan Polisi Pamong Praja belum sepenuhnya dilaksanakan dalam menertiban pedagang kaki lima di Kota Subang. Terbukti dari Lima Puluh Tiga lapak para pedagang kaki lima yang ada ditempat tempat trotoar / fasilitas umum ternyata masih adanya Dua Puluh Tujuh lapak pedagang kaki lima yang belum ditertibkan dan sering terjadinya bongkar pasang lapak pedagang kaki lima.

3. Keandalan dan sikap pegawai Satuan Polisi Pamong Praja dalam melaksanakan penertiban pedagang kaki lima di Kota Subang belum sepenuhnya dilaksanakan. Ini terbukti Tiga kali terjadinya keributan antara pedagang dan pegawai Satuan Polisi Pamong Praja dalam penertiban / pembersihan lapak pedagang kaki lima.

Tabel 1.1.

Tabel Permasalahan

\begin{tabular}{|c|c|c|c|}
\hline No. & Permasalahan & Target & Realisasi \\
\hline 1. & $\begin{array}{c}\text { Kualitas Pegawai Satuan Polisi } \\
\text { Pamong Praja Belum Optimal }\end{array}$ & 1 Hari & 2 Hari \\
\hline 2. & $\begin{array}{c}\text { Tingkat kuantitas pegawai Satuan } \\
\text { Polisi Pamong Praja belum } \\
\text { optimal dalam menertiban } \\
\text { pedagang kaki lima di Kota } \\
\text { Subang }\end{array}$ & 53 PKL & 26 PL \\
\hline 3. & $\begin{array}{c}\text { Keandalan dan sikap pegawai } \\
\text { Satuan Polisi Pamong Praja dalam } \\
\text { melaksanakan penertiban } \\
\text { pedagang kaki lima di Kota } \\
\text { Subang belum optimal }\end{array}$ & $\begin{array}{c}\text { Tidak terjadi } \\
\text { Keributan }\end{array}$ & $\begin{array}{c}3 \text { Kali terjadi } \\
\text { Keributan }\end{array}$ \\
\hline
\end{tabular}

Dengan kata lain bahwa Kinerja pegawai tersebut masih rendah diduga

disebabkan oleh implementasi kebijakan yang belum sepenuhnya dilaksanakan.

Kinerja pegawai di Satuan Polisi Pamong Praja mengalami kendala, kesulitan, 
melaksanakan tugas, fungsi dan tanggungjawab di dalam penegakan implementasi kebijakan atau peraturan pemerintah daerah itu sehingga perlu dicarikan pemecahan masalahnya.

Berpedoman pada uraian latar belakang, peneliti tertarik untuk melakukan penelitian lebih lanjut tentang masalah tersebut dalam berbentuk tesis dengan judul : Pengaruh Implementasi Kebijakan Terhadap Kinerja Pegawai Di Kantor Satuan Polisi Pamong Praja Kabupaten Subang. (Studi Implementasi Mengenai Peraturan Daerah Kabupaten Subang No. 13 Tahun 2006 Tentang Ketertiban, Kebersihan dan Keindahan)

\subsection{Identifikasi Masalah}

Berdasarkan latar belakang penelitian yang penulis uraikan, maka penulis mengindentifikasikan masalah tersebut sebagai berikut :

1. Berapa besar pengaruh implementasi kebijakan terhadap kinerja pegawai di Kantor Satuan Polisi Pamong Praja Kabupaten Subang?.

2. Berapa besar pengaruh implementasi kebijakan melalui faktor Standar dan Sasaran Kebijakan, Sumber daya, Karakteristik organisasi pelaksana, Komunikasi antar organisasi pelaksana dan kegiatan-kegiatan pelaksanaan, Sikap para pelaksana, Lingkungan sosial ekonomi dan politik, terhadap kinerja pegawai di Kantor Satuan Polisi Pamong Praja Kabupaten Subang ?.

\subsection{TUJUAN DAN KEGUNAAN PENELITIAN}

\subsubsection{Tujuan Penelitian}


1. Menganalisis besarnya pengaruh implementasi kebijakan terhadap kinerja pegawai di Kantor Satuan Polisi Pamong Praja Kabupaten Subang.

2. Mengembangkan konsep implementasi kebijakan konsep kinerja pegawai di Kantor Satuan Polisi Pamong Praja Kabupaten Subang.

3. Menerapkan secara teoritis konsep implementasi kebijakan untuk memecahkan masalah kinerja pegawai di Kantor Satuan Polisi Pamong Praja Kabupaten Subang.

\subsubsection{Kegunaan Penelitian}

1. Secara teoritis, hasil penelitian ini dapat berguna sebagai bahan pemikiran selanjutnya, dan untuk perkembangan ilmu pengetahuan umumnya, khususnya kajian disiplin ilmu administrasi yang berkaitan dengan implementasi kebijakan dan kinerja pegawai.

2. Secara Praktis, diharapkan dapat memberikan kontribusi pemikiran untuk menjadi bahan alternatif pemikiran atau pertimbangan sebagai masukan bagi Kantor Satuan Polisi Pamong Praja Kabupaten Subang yang berkaitan dengan Pengaruh Implementasi Kabijakan dan Kinerja Pegawai.

3. Bagi Penulis, penelitian ini diharapkan bermanfaat untuk menambahkan wawasan pengetahuan dan pengalaman yang berharga dalam menganalisis suatu fenomena administrasi dan membandingkan dengan teori-teori di peroleh sebelumnya.

4. Bagi pihak lain, penelitian ini sebagai bahan kajian dan perkembangan teori dalam disiplin Ilmu Administrasi dan pengembangannya yang berlangsung 
dalam suatu organisasi. Selain itu, hasil penelitian ini dapat dijadikan dasar bagi penelitian lainnya untuk mengkai permasalahan yang sama. 


\section{BAB II}

\section{KAJIAN PUSTAKA, KERANGKA PEMIKIRAN DAN HIPOTESIS}

\subsection{Kajian Pustaka}

Kajian pustaka merupakan salah satu dari beberapa teori yang akan digunakan oleh penulis untuk memperjelas dari penelitian yang akan digunakan sesuai dengan judul yang akan diteliti oleh penulis. Selain itu, kajian pustaka ini juga untuk memperkuat kerangka penelitian yang akan diteliti oleh penulis.

\subsubsection{Hasil Penelitian Sebelumnya}

Beberapa penelitian sebelumnya yang berkaitan dengan implementasi kebijakan dan kinerja pegawai menjadi rujukan bagi penulis untuk mengembangkan lebih lanjut, diantaranya penelitian yang ditulis oleh, yaitu :

\section{Hasil Penelitian Endang}

Endang (2007) melakukan penelitian ini didasarkan pada masalah pokok kinerja pegawai rendah pada Perusahaan Daerah Kebersihan Kota Bandung, hal ini diduga disebabkan oleh belum dijalankan faktor-faktor implementasi kebijakan secara efektif. Dengan judul penelitiaan "Pengaruh Implementasi Kebijakan Pengelolaan Kebersihan Terhadap Kinerja Pegawai Pada Perusahaan Daerah Kebersihan Kota Bandung”.

Metode yang digunakan dalam penelitian ini adalah survei, dan pendekatan penelitiannya menggunakan deskritif. Metode ini untuk menjelaskan fenomena sosial dalam hal ini meneliti pengaruh implementasi 
kebijakan (variabel bebas) dengan simbol (X), terhadap kinerja pegawai (variabel terikat) dengan simbol (Y). Penelitian ini menggunakan analisis kuantitatif melalui analisis jalur (path analysis) yang dimaksudkan untuk mengetahui besaran pengaruh variabel implementasi kebijakan terhadap kinerja pegawai pada Perusahaan Daerah Kebersihan Kota Bandung, baik secara parsial maupun secara simultan.

Hasil penelitian menunjukkan bahwa secara parsial implementasi kebijakan (X) yang terdiri dari faktor-faktor implementasi kebijakan yaitu target dan tujuan (X1) berpengaruh secara signifikan terhadap kinerja pegawai (Y) sebesar 0,533 atau 53,3\%, sumber kebijakan (X2) berpengaruh signifikan terhadap kinerja pegawai $(\mathrm{Y})$ sebesar 0,628 atau $62,8 \%$, ciri-ciri atau sifat badan pelaksana (X3) berpengaruh secara signifikan terhadap kinerja pegawai (Y) sebesar 0,767 atau 76,7 \%, hubungan dengan lembaga lain (X4) berpengaruh secara signifikan terhadap kinerja pegawai $(\mathrm{Y})$ sebesar 0,556 atau 55,6 \% dan lingkungan esospol (X5) 0,641 atau 64,1\%. Sedangkan secara simultan implementasi kebijakan (X) berpengaruh terhadap kinerja pegawai (Y) sebesar 0,822 atau $82,2 \%$, pengaruh lainnya diluar faktor-faktor implementasi kebijakan sebesar 0,178 atau 17,8\%. Dari kelima faktor-faktor implementasi kebijakan tersebut, yang memberikan pengaruh dominan secara parsial terhadap kinerja pegawai yaitu faktor ciri-ciri atau sifat badan pelaksana (X3) dengan besaran nilai 0,767 atau 76,6\%. 
Hasil penelitian dari Endang dapat disimpulkan, faktor-faktor implementasi kebijakan secara parsial belum menyeluruh dilaksanakan oleh pegawai Perusahaan Daerah Kebersihan Kota Bandung, kemudian implementasi kebijakan secara simultan berpengaruh signifikan terhadap kinerja pegawai pada Perusahaan Daerah Kebersihan Kota Bandung. Hasil penelitian mengungkapkan bahwa kinerja pegawai pada Perusahaan Daerah Kebersihan Kota Bandung ternyata tidak hanya dipengaruhi oleh variabel implementasi kebijakan saja, akan tetapi dipengaruhi faktor lain. faktor target dan tujuan merupakan faktor yang paling kecil memberikan pengaruh terhadap kinerja pegawai. Sedangkan sikap para pelaksana merupakan faktor yang paling besar memberikan pengaruh terhadap kinerja pegawai pada Perusahaan Daerah Kebersihan Kota Bandung, bahwa implementasi kebijakan dengan beberapa faktornya dapat meningkatkan kinerja pegawai selain itu juga hubungan dengan badan pelaksana yang lain sangat mempengaruhi proses pelaksanaan implementasi kebijakan.

2. Hasil Penelitian Farida Agustini

Agustini (2008) melakukan penelitian ini berdasarkan pada masalah pokok kinerja pegawai rendah pada Komisi Pemilihan Umum Kab. Bandung, hal ini diduga disebabkan oleh belumnya dijalankan pengorganisasian secara efektif. Dengan judul penelitiaan "Pengaruh Implementasi Kebijakan Terhadap Kinerja Pegawai Pada Komisi Pemilihan Umum Kabupaten Bandung”. 
Metode yang digunakan dalam penelitian ini adalah metode survei deskritif analisis, metode ini untuk menjelaskan fenomena sosial dalam hal ini meneliti pengaruh implementasi kebijakan (variabel bebas) dengan simbol (X), terhadap kinerja pegawai (variabel terikat) dengan simbol (Y). Penelitian ini menggunakan analisis kuantitatif melalui analisis jalur (path analysis) yang dimaksudkan untuk mengetahui besaran pengaruh variabel implementasi kebijakan terhadap kinerja pegawai pada Komisi Pemilihan Umum Kabupaten Bandung, baik secara parsial maupun secara simultan.

Hasil penelitian menunjukkan bahwa secara parsial implementasi kebijakan (X) yang terdiri dari empat faktor-faktor implementasi kebijakan yaitu faktor komunikasi (X1) berpengaruh secara signifikan terhadap kinerja pegawai (Y) sebesar 0,4489 atau 44,89 \%, faktor sumber daya (X2) berpengaruh signifikan terhadap kinerja pegawai (Y) sebesar 0,121 atau 12,1 $\%$, faktor disposisi / sikap pelaksana (X3) berpengaruh secara signifikan terhadap kinerja pegawai (Y) sebesar 0,1369 atau 13,69\% dan faktor struktur birokrasi (X4) berpengaruh secara signifikan terhadap kinerja pegawai (Y) sebesar 0,676 atau 6,76\%. Sedangkan secara simultan implementasi kebijakan (X) berpengaruh terhadap kinerja pegawai (Y) sebesar 0,533 atau 53,3\%, pengaruh lainnya diluar faktor-faktor implementasi kebijakan sebesar 0,477 atau 47,7\%. Dari keempat faktor-faktor implementasi kebijakan tersebut, yang memberikan pengaruh dominan secara parsial terhadap kinerja pegawai yaitu faktor komunikasi (X1) dengan besaran nilai 0,4489 atau 44,89\%. 
Hasil penelitian dari Agustini dapat disimpulkan, bahwa faktor-faktor implementasi kebijakan secara parsial belum menyeluruh dilaksanakan oleh pegawai Komisi Pemilihan Umum Kabupaten Bandung, dan implementasi kebijakan secara simultan berpengaruh signifikan terhadap kinerja pegawai pada komisi pemilihan umum kabupaten Bandung. Keterkaitan antara kinerja pegawai dengan komunikasi, sebab meningkatnya kinerja pegawai dapat meningkatkan komunikasi yang menyebabkan tingkat pemahaman pegawai terhadap kompetensinya meningkat. Hasil penelitian ini yang sudah dilakukan sebelumnya menggambarkan bahwa kinerja pegawai dapat meningkat apa bila sumber daya manusianya sudah handal.

Relevansi dari hasil penelitian Endang dan Agustini, bahwa masih adanya beberapa faktor yang mempengaruhi didalamnya, seperti aspek daya tanggap, sikap para pelaksana dan hubungan dengan badan / organisasi pelaksana. Selain itu juga adanya beberapa faktor seperti sumber daya, sikap pelaksana dan komunikasi. Penulis tertarik untuk meneliti lebih lanjut dan mengembangkan lagi dengan penelitian yang sudah dilakukan oleh peneliti sebelumnya dan dapat dijadikan sebagai bahan pertimbangan maupun perbandingan dalam proses penulisan. Peneliti benar-benar tertarik untuk mengambil judul penelitian tentang pengaruh implementasi kebijakan terhadap kinerja pegawai.

\subsubsection{Tinjauan Administrasi Publik}

Administrasi dan manajemen dalam suatu organisasi harus bergerak ditempat yang serba terbatas. Oleh karena itu, administrasi memiliki arti yang 
sangat luas. Definisi administrasi menurut Siagian dalam Suhendra (2008:8), yaitu : “Administrasi adalah Keseluruhan proses pelaksanaan kegiatan yang dilakukan oleh dua orang atau lebih yang terlibat dalam suatu bentuk bersama demi tercapainya tujuan yang telah ditentukan sebelumnya”. Sedangkan menurut The Liang Gie dalam Silalahi (2007:9), mendefinisikan “Administrasi adalah segenap rangkaian kegiatan penataan terhadap pekerjaan pokok yang dilakukan oleh sekelompok orang di dalam kerjasama mencapai tujuan tertentu”.

Definisi di atas menurut Siagian dan The Liang Gie, mengandung arti bahwa administrasi menunjukan adanya tujuan atau sasaran yang ditentukan sebelum melaksanakan suatu pekerjaan, adanya kerjasama baik sekelompok orang atau lembaga pemerintah maupun lembaga swasta, dan adanya sarana yang digunakan oleh sekelompok atau lembaga dalam melaksanakan tujuan yang hendak dicapai.

Definisi administrasi publik menurut Waldo dalam Pasolong (2008:8), menjelaskan yaitu "administrasi publik adalah manajemen dan organisasi dari manusia dan peralatannya guna mencapai tujuan pemerintah". Menurut pendapat Rosenbloom dalam Pasolong (2008:7), yaitu :

Administrasi publik merupakan pemanfaatan teori-teori dan prosesproses manajemen, politik dan hukum untuk memenuhi keinginan pemerintah dibidang legislatif, eksekutif, dalam rangka fungsi-fungsi pengaturan dan pelayanan terhadap masyarakat secara keseluruhan atau sebagian.

Definisi menurut Waldo dan Ronsenbloom dapat dijelaskan dari kedua pendapat itu, bahwa administrasi itu terkandung sifat yang fungsional. Fungsinya, 
bisa dipahami sebagai management (servis/pelayanan). Berarti penyelengaraan administrssi menekankan pada manajemen yang merupakan praktik pelaksanaanya, administrasi dan manajemen berada dalam suatu sistem hubungan, bagaikan antara prinsip dan realitasnya, atau bagaikan hubungan subtansi dan eksistensinya. Penyelenggaraan administrasi sering disebut dengan administrator dan peneyelengaraan manajemen sering disebut manajer, dapat diartikan sebagai proses kegiatan pencapaian tujuan negara atau pemerintah yang telah ditetapkan sebelumnya. Keduanya tidak dapat dipisahkan karena administrasi memiliki peran sebagai proses dan manajemen memiliki sebagai penggerak pencapaian tujuan negara / pemerintah berada dalam satu wadah yaitu organisasi.

Administrasi merupakan kegiatan yang sangat luas dalam penyelenggaraan Negara sebagaimana yang hendak dikemukan oleh White dalam Indiahono (2009:3), bahwa ada empat asumsi dasar dari administrasi publik yaitu sebagai berikut :

1. Administrasi adalah suatu kesatuan proses yang dapat dipelajari secara seragam di pemerintah pusat, negara dan tingkat lokal,

2. Dasar dari studi adalah manajemen, bukan hukum,

3. Administrasi adalah bagian dari seni, tetapi tranformasi ideal dari ilmu adalah memenuhi dua hal ; mungkin dan bermanfaat, dan

4. Pengenalan administrasi, bahwa administrasi telah menjadi, dan akan terus berkembang sebagai kajian yang membahas permasalahan dalam pemerintahan modern.

Administrasi publik (public administration) yang lebih dikenal di Indonesia dengan istilah administrasi Negara, adalah salah satu aspek dari kegiatan pemerintah. Administrasi publik merupakan salah satu bagian dari ilmu 
administrasi yang erat kaitanya dengan perumusan berbagai kebijakan Negara. Administrasi publik sangatlah berpengaruh tidak hanya terhadap tingkat perumusan kebijakan, melainkan pula pada tingkat implementasi kebijakan, karena memang administrasi publik berfungsi untuk mencapai tujuan program yang telah ditentukan oleh pembuat kebijakan politik.

Peran administrasi publik dalam mewujudkan kebijakan-kebijakan politik serta mewujudkan rasa aman dan kesejahteraan masyarakat, melalui kegiatan yang bersifat rutin maupun pembangunan, pemerintah memerlukan administrasi publik yang berdaya guna dan berhasil guna.

Peran administrasi atau administrasi publik merupakan proses perumusan kebijakan sebagaimana Nigro dalam Pamudji (2004:8) yaitu

Administrasi publik adalah suatu kerjasama kelompok dalam lingkungan pemerintahan, meliputi ketiga cabang pemerintahan eksekutif, legislatif dan yudikatif serta hubungan antara meraka mempunyai peranan penting dalam perumusasn kebijakan umum/Negara dan oleh karenanya merupakan sebagaian dari proses politik, dalam beberapa hal berbeda dengan administrasi private, sangat erat berkaitan dengan berbagai macam kelompok swasta dan perorangan dalam menyajikan pelayanan kepada masyarakat.

Pendapat Pfiffner dan Presthus dalam Pasolong (2008:7) mendefinisikan administrasi publik adalah sebagai berikut :

Administrasi publik ialah (1) meliputi implementasi kebijakan pemerintah yang telah ditetapkan oleh badan-badan perwakilan politik, (2) koordinasi usaha-usaha perorangan dan kelompok untuk melaksanakan kebijakan pemerintah, hal ini meliputi pekerjaan seharihari pemerintah., (3) suatu proses yang bersangkutan dengan pelaksanaan kebijakan - kebijakan pemerintah, pengarahan kecakapan dan teknik-teknik yang tidak terhingga jumlahnya, memberikan arah dan maksud terhadap usaha sejumlah orang. 
Pendapat lain mengenai administrasi publik yaitu menurut Chandler dan Plano dalam Pasolong (2008:7) adalah sebagai berikut :

Administrasi publik merupakan seni dan ilmu (art and science) yang ditujukan untuk mengatur public affairs dan melaksanakan berbagai tugas yang ditentukan. Administrasi publik sebagai disiplin ilmu untuk memecahkan masalah publik melalui perbaikan-perbaikan terutama dibidang organisasi, sumber daya manusia dan keuangan.

Definisi administrasi publik di atas menurut Nigro, Pfiffner dan Presthus serta Chandler dan Plano, dapat dipahami bahwa administrasi publik adalah kerjasama yang dilakukan oleh sekelompok orang atau lembaga dalam melaksanakan tugas-tugas pemerintahan dalam memenuhi kebutuhan publik secara efesien dan efektif atau merupakan suatu proses yang melibatkan beberapa orang dangan berbagai keahlian dan kecakapan untuk melaksanakan kebijakankebijakan pemerintah.

Secara khusus administrasi publik di Indonesia telah didefinisikan menurut Napitupulu (2008:18), yaitu sebagai berikut :

Administrasi Negara Republik Indonesia adalah seluruh penyelengaraan kekuasaan pemerintah Negara Indonesia dengan memanfaatkan segala kemampuan aparatur Negara serta segenap dana dan daya demi tercapainya tujuan Negara Indonesia dan terlaksananya tugas pemerintah Republik Indonesia seperti yang ditetapkan dalam Undang-Undang Dasar 1945 dan Amandemen-amandemennya yang sudah empat tahap dilakukan oleh anggota MPR-RI, Amandemen itu mneimbulkan pro dan kontra dalam elemen bangsa Indonesia, yaitu antara yang mendukung dan menentang. 
Penyelengaraan administrasi publik dapat berlangsung dengan efektif harus diimbangi dengan sumber - sumber yang lengkap dan tepat. Sumbersumber manajemen, menurut Suhendra (2008:27-28) sebagai berikut :

1. Man (Sumber daya manusia dengan keahlian tertentu sesuai dengan kebutuhan organisasi dalam mencapai tujuan),

2. Money (Modal dalam bentuk uang yang dibutuhkan untuk berbagai bentuk biaya, penggajian, atau merupakan unsur sarana maupun prasaran untuk mencapai tujuan),

3. Machine (mesin atau alat yang diperlukan atau dipergunakan untuk mencapai tujuan),

4. Material (bahan / alat untuk melaksnakan pekerjaan sebagai media yang digunakan untuk melaksanakan semua kegiatan oleh manusia),

5. Methode (cara kerja yang dipergunakan dalam usaha pencapaian tujuan),

6. Market (sebagai bahagian dari pelayan publik dalam mensosialisasikan "memasrkan" jasa dengan standar kinerja).

Sumber-sumber manajemen atau $(6 \mathrm{M})$ tersebut, bila diterapkan maka proses penyelengaraan administrasi publik akan tercapai.

\subsubsection{Tinjauan Kebijakan Publik dan Implementasi Kebijakan Publik}

Implementasi kebijakan merupakan sesuatu yang penting. Kebijakan publik yang dibuat hanya akan menjadi macan kertas apabila tidak berhasil dilaksanakan. Oleh karena itu, implementasi kebijakan publik perlu dilakukan dengan mempertimbangkan faktor atau berbagai faktor, agar kebijakan publik yang dimaksud benar-benar dapat berfungsi sebagai alat untuk merealisasikan harapan yang diinginkan. Dengan kata lain, implementasi kebijakan merupakan upaya untuk merealisasikan suatu keputusan atau kesepakatan yang telah ditetapkan sebelumnya. 
Sekalipun impelementasi kebijakan memainkan peran penting dalam merealisasikan kebijakan misi suatu kebijakan publik, tetapi tidak berarti bahwa implementasi kebijakan publik terpisah dari tahapan formulasi. Putra dalam Tachjan (2008:xii), mengatakan "bahwa keberhasilan suatu kebijakan publik sangat tergantung pada tatanan kebijakan publik makro dan mikro yang ditetapkan". Dapat dijelaskan bahwa formulasi kebijakan publik makro akan ditetapkan dalam peraturan perundang-undangan yang berlaku, keberhasilan implementasinya akan dipengaruhi oleh kebijakan operasional serta kelompok sasaran dalam mencermati lingkungan.

Kebijakan publik tidak hanya mencangkup operasionalisasi kebijakan publik ke dalam mekanisme birokratis, tapi terkait juga dengan bagaimana agar kebijakan publik tersebut dapat diterima, dipahami, dan didukung oleh masyarakat atau kelompok sasaran. Hal ini merupakan bagian dari proses politik. Sebagai bagian dari proses politik, maka implementasi kebijakan juga perlu memperhatikan berbagai jaringan kekuatan politik, ekonomi dan sosial yang berpengaruh pada perilaku semua pihak yang terlibat, sehingga kebijakan publik tersebut dapat mencapai harapan yang diinginkan.

Melengkapi konsep di atas menurut Thoha (2008:106-107), mengemukakan kebijakan dalam arti yang luas mempunyai dua aspek pokok, yaitu antara lain :

1. Kebijakan merupakan praktika sosial, ia bukan event yang tunggal atau terisolir. Dengan demikian suatu yang dihasilkan pemerintah berasal dari segala kejadian dalam masyarakat dan dipergunakan pula untuk kepentingan masyarakat. Kejadian semacam ini tumbuh 
dalam pratika kehidupan masyarakat, dan tidak merupakan peristiwa yang berdiri sendiri, terisolasi dan asing bagi masyarakat.

2. Kebijakan adalah suatu peristiwa yang ditimbulkan oleh baik untuk mendamaikan claim dari pihak-pihak konflik, atau untuk menciptakan incentive bagi tindakan bersama bagi pihak-pihak yang ikut menetapkan tujuan akan tetapi mendapatkan perlakuan yang tidak rasional dalam usaha bersama tersebut. Dengan demikian jika ada pihak-pihak yang konflik, maka usaha untuk mengatasinya antara lain dihasilkan suatu kebijakan. Selain itu, jika terjadi beberapa pihak yang bersama-sama ikut menentukan tujuan yang ingin dicapai bersama, akan tetapi dalam perjalannya ada pihak-pihak yang mendapatkan perlakuan yang tidak sama dan tidak rasional. Maka diciptakan suatu tindakan yang berupa kebijakan yang dapat mendorong agar diciptakan situasi yang rasional. Kebijakan semacam ini merupakan dorongan atau incentive bagi pihak-pihak untuk bersama-sama bekerja secara rasional.

Kedua aspek pokok yang dikemukakan oleh Thoha dapat dijelaskan bahwa kebijakan di satu pihak dapat berbentuk suatu usaha yang komplek dari masyarakat untuk kepentingan masyarakat, di lain pihak kebijakan merupakan suatu teknik atau cara untuk mengatasi konflik dan menimbulkan insentif. Pendapat lainnya mengemukakan bahwa kebijakan menurut Friedrich dalam Wahab (2004:3),yaitu :

Kebijakan adalah tindakan yang mengarah pada tujuan yang diusulkan seseorang, kelompok atau pemerintah dalam lingkungan tertentu sehubungan dengan adanya hambatan - hambatan seraya mencari peluang untuk mencapai tujuan atau mewujudkan sasaran yang diinginkan.

Mirip dengan pendapat Friedrich di atas, Anderson dalam Wahab (2004:3) merumuskan kebijakan yaitu "langkah tindakan yang secara sengaja dilakukan oleh seorang aktor atau sejumlah aktor berkenaan dengan adanya masalah atau 
persoalan tertentu yang dihadapi”. Dari kedua pernyataan tersebut mengandung makna bahwa kebijakan negara ini seyogianya diarahkan pada apa yang senyatanya dilakukan oleh pemerintah dan bukan sekedar apa yang ingin dilakukan. Di samping itu pernyataaan tersebut juga membedakan secara tegas antara kebijakan dan keputusan, yang mengandung arti pemilihan di antara sejumlah alternatif yang tersedia. dibuat dan ditetapkan sehubungan dengan adanya suatu masalah yang dihadapi, atau mempunyai pengertian lain bahwa sebuah kebijakan dibuat berdasarkan kepentingan-kepentingan seseorang, kelompok serta pemerintah itu sendiri.

Pernyataan senada dikemukan oleh Jenkins dalam Wahab (2004:4), yang merumuskan kebijakan yaitu sebagai berikut :

A set of interrelated decisions taken by a political actor or group of actors concerning the selection of goal and the means of achieving them within a specified situation of goals and these decisions should, in principle, be within the power of these actors to achieve. (serangkaian keputusan yang paling berkaitan yang diambil oleh seorang aktor politik atau sekolompok aktor politik yang berkenaan dengan tujuan yang telah dipilih berserta cara-cara untuk mencapainya dalam suatu situasi di mana keputusan-keputusan itu pada prinsipnya masih berada dalam batas-batas kewenangan kekuasaan dari para aktor tersebut).

Kata public policy secara pendekatan pilologis atau etimologis, diterjemahkan kedalam bahasa Indonesia menjadi kebijakan publik atau sering dikenal dengan kebijakan pemerintah. Menurut Anderson dalam Subarsono (2008:2) mengemukakan "bahwa kebijakan publik sebagai kebijakan yang ditetapkan oleh badan-badan dan aparat pemerintah. Sedangkan menurut Dye 
dalam Pasolong (2008:39), mengemukakan bahwa kebijakan publik yaitu sebagai berikut :

Apapun yang dipilih pemerintah untuk dilakukan atau tidak dilakukan Apabila pemerintah memilih untuk melakukan sesuatu maka harus ada tujuannya (objektif) dan kebijakan Negara itu harus meliputi semua tindakan pemerintah. Jadi bukan semata-mata merupakan pernyataaan keinginan pemerintah atau pejabat pemerintah saja.

Kebijakan berawal dari kebutuhan dan tuntutan masyarakat, dengan kata lain Bahwa lahirnya suatu kebijakan berdasarkan atas masalah yang terjadi dikalangan masyarakat. Kebijakan yang diambil oleh pemerintah sebagai administrator Publik harus berorientasi dan mengabdi pada kepentingan masyarakat.

Kebijakan publik menitik beratkan pada publik dan masalah-masalahnya. Kebijakan publik membahas bagimana isu-isu dan persoal tersebut disusun, didefenisikan serta bagaimana persoalan tersebut diletakan dalam agenda kebijakan. Selain itu, kebijakan publik juga merupakan studi bagaimana, mengapa, dan apa efek dari tindakan aktif dan pasif pemerintah atau kebijakan publik.

Proses penyusunan kebijakan publik menurut Howlet dan Ramesh dalam Subarsono (2008:13-14), proses kebijakan publik terdiri dari lima tahap yaitu sebagai berikut :

1. Penyusunan Agenda, yakni suatu proses agar suatu masalah bisa mendapat perhatian dari pemerintah,

2. Formulasi kebijakan, yakni proses perumusan pilihan-pilihan kebijakan oleh pemerintah, 
3. Pembuatan kebijakan, yakni proses ketika pemerintah memilih untuk melakukan sesuatu tindakan,

4. Implementasi Kebijakan, yakni proses untuk melaksanakan kebijakan supaya mencapai hasil,

5. Evaluasi kebijakan, yakni proses untuk memonitor dan menilai hasil atau kinerja kebijakan.

Kebijakan publik suatu analisis yang mendalam terhadap berbagai alternatif yang bermuara kepada keputusan tentang alternatif terbaik terhadap publik yang di tetapkan oleh pemerintah antara dilakukan atau tidak dilakukan. Ada pun pendapat Menurut Fermana (2009:34-35), kebijakan publik yaitu :

Apa yang dilakukan pemerintah, mengapa pemerintah mengambil tindakan tersebut, dan apa akibat dari tindakan tersebut, lebih spesifiksinya lagi kebijakan publik adalah studi tentang keputusan dan tindakan pemerintah yang disusun untuk kepentingan publik.".

Penjelasanya dari pendapat Fermana bahwa kebijakan publik adalah pemanfaatan yang strategis terhadap sumber-sumber daya yang ada untuk memecahkan masalah publik atau pemerintah. Peran pemerintah atau administrator publik memegang posisi yang sangat penting dalam proses pembuat kebijakan.

Menurut Hoogerwerf dalam Tachjan (2008:14), mengemukakan "bahwa fungsi sentral dari pemerintah adalah menyiapkan, menentukan dan menjalankan kebijakan atas nama dan untuk keseluruhan masyarakat di daerah kekuasaanya". Sedangkan menurut Kartasasmita dalam Widodo (2009:12-13), mengemukakan sebagai berikut :

Merupakan upaya untuk memahami dan mengartikan (1) apa yang dilakukan pemerintah (atau tidak dilakukan) oleh pemerintah mengenai 
suatu masalah, (2) apa yang menyebabkan atau yang mempengaruhinya, (3) apa pengaruh dan dampak dari kebijakan publik tersebut.

Berbeda dengan pendapat Kartasamita dalam Widodo "bahwa kebijakan itu apa yang dilakukan pemerintah atau tidak dilakukan pemerintah mengenai suatu masalah, apa penyebabnya dan apa pengaruh dampak kebijakan publik". Melainkan menurut Dunn (2008:109), mengemukan "Kebijakan publik merupakan rangkaian pilihan yang kurang lebih saling berhubungan (termasuk keputusan-keputusan untuk tidak bertindak) yang dibuat oleh badan dan pejabat pemerintah".

Pendapat yang telah dikemukan oleh kartasasmita dan dunn dapat dijelaskan bahwa pada intinya keputusan dan pembuatan kebijakan publik oleh pemerintah adalah kebijakan publik terdiri dari keputusan politis untuk menimplementasikan program dalam meraih tujuan demi kepentingan masyarakat. Kebijakan publik dibuat oleh pemerintah yang berupa tindakantindakan pemerintah, yang harus berorientasikan kepada kepentingan publik, serta dalam pemilihan alternatif untuk dilaksanakan atau tidak dilaksanakan oleh pemerintah demi kepentingan publik. Kebijakan publik juga tidak hanya meliputi keinginan nyata tetapi juga tidak nyata, akan tetapi Dye dalam Subarsono (2008:2), mengemukakan pendapatnya bahwa "kebijakan publik tersebut dibuat oleh badan pemerintah,bukan badan swasta dan kebijakan publik menyangkut pilihan yang harus dilakukan atau tidak dilakukan oleh badan pemerintah". 
Namun kenyataannya sulit untuk menentukan kebijakan pemerintah yang nyata dan tidak nyata.

Penggunaan istilah kebijakan antara keputusan pemerintah, telah mendapatkan penurunan dari banyak guru besar tata Negara, karena keputusan atau kebijakan pemerintah memiliki kesamaan yaitu mempunyai wewenang atau kekuasaan untuk mengarahkan masyarakat serta bertanggung jawab melayani kepentingan umum. LAN RI (1994:149) mengemukakan bahwa kebijakan adalah;

Kebijakan pada dasarnya merupakan ketentuan-ketentuan yang harus dijadikan pedoman, pegangan atau petunjuk, cara bagi setiap usaha kegiatan aparatur pemerintah, sehingga tercapai kelancaran dan keterpaduan dalam mencapai tujuan tertetnu, dalam penyusunan kebijakan harus :

1) berpedoman pada kebijakan yang tingkatannya lebih tinggi,

2) tidak boleh bertentangan dengan kebijakan yang ada harus objektif,

3) jelas, tepat dan tidak menimbulkan kekaburan bagi para pelaksana.

Kebijakan berdasarkan kebijakan nasional menurut LAN RI (1994;149) yaitu "kebijakan nasional merupakan kebijakan Negara yang bersifat fundamental dan strategis dalam pencapaian tujuan nasional/Negara sebagaimana tertera dalam UUD 1945”. Akan tetapi menurut Naihasy (2006:29-31) secara umum kebijakan dapat dibedakan ke dalam tiga strata yaitu sebagai berikut :

1. Kebijakan umum, adalah kebijakan yang menjadi pedoman atau petunjuk pelaksanaan baik yang bersifat positif maupun yang negatif yang meliputi keseluruhan wilayah atau instasnsi.

2. Kebijakan Pelaksanaan, adalah kebijakan yang menjabarkan kebijakan umum.

3. Kebijakan teknis, adalah kebijakan operasional yang berbeda terhadap kebijakan pelaksanaan. 
Kebijakan nasional, kebijakan umum, kebijakan pelaksanaan dan kebijakan teknis, semuanya itu dalam rangka pencapaian tujuan bangsa dan negara akan tetapi di dalam pencapaianya faktor lingkungan pasti akan mempengaruhinya. Menurut Anderson dalam Widodo (2009:13), mengartikan "kebijakan publik sebagai suatu respons dari sistem politik terhadap demands/claims dan suports yang mengalir dari lingkungannya". Berdasarkan pengertian tersebut, Dye dalam Widodo (2009:13), mengemukakan "sistem kebijakan terdapat tiga elemen, yaitu (a) kebijakan publik, (b) pelaku kebijakan, dan (c) lingkungan kebijakan". Kemudian menurut Dunn (2000:110), juga mengemukakan "bahwa dalam sistem kebijakan terdapat tiga elemen, yaitu (a) kebijakan publik, (b) pelaku kebijakan, (c) lingkungan kebijakan”.

Mustopadidjaja dalam Widodo (2009:13), menambahkan "satu elemen yaitu kelompok sasaran (target Groups)". Sementara menurut Easton dalam Widodo (2009:13), mengemukakan "sistem terdiri atas unsur inputs, process, outputs, feedback, dan lingkungan”. Lingkungan kebijakan dibagi dalam dua macam, yaitu intra dan extra societal environment. Dalam lingkungan ini mengalir dua inputs yaitu demands/claims dan support yang kemudian diproses ke dalam sistem politik yang selanjutnya melahirkan policy outputs, berupa policy dan descesion. Policy outputs kembali ke social environment sebagai respons (feedbacks) terhadap demands/claims dari social environments.

Atas dasar beberapa yang telah dikemukaan di atas, maka dapat ditemukan elemen yang terkandung dalam kebijakan publik sebagaimana apa 
yang dikemukakan Anderson dalam Widodo (2009:14) yang antara lain mencakup beberapa hal berikut :

1. Kebijakan selalu mempunyai tujuan atau berorientasi pada tujuan tertentu,

2. Kebijakan berisi tindakan atau pola tindakan pejabat-pejabat pemerintah,

3. Kebijakan adalah apa yang benar-benar dilakukan pemerintah dan bukan apa yang bermasksud akan dilakukan,

4. Kebijakan publik bersifat positif (merupakan tindakan mengenai suatu masalah tertentu) dan bersifat negarif( keputusan pejabat pemerintah untuk tidak melakukan sesuatu),

5. Kebijakan publik (posistif) selalu berdasarkan pada peraturan perundangan tertentu yang bersifat memaksa (otoritatif).

Berdasarkan pengertian dan elemen yang terkandung dalam kebijakan sebagaimana telah disebutkan, maka kebijakan publik dibuat dalam rangka untuk memecahkan dan untuk mencapai tujuan dan sasaran tertentu yang diinginkan. Kebijakan publik dibuat bukannya tanpa maksud ddan tujuan. Maksud dan tujuan kebijaakn publik dibuat adalah untuk memecahkan masalah publik yang tumbuh kembang di masyarakat. Maslah tersebut begitu banayak macam, variabel, dan intensitasnya. Oleh karena itu, tidak semua masalah publik tadi bisa melahirkan suatu kebijakan publik. Hanya masalah publik yang dapat menggerakan orang banyak ikut memikirkan yang dapat menggerakan orang banyak untuk ikut memikirkan dan mencari solusi yang bisa menghasilkan sebuah kebijakan publik.

Kebijakan yang berkembang oleh lembaga-lembaga Negara dan pejabat pemerintah, menurut Islamy (2000:12) adalah

Sekalipun kebijakan publik merupakan kebijakan-kebijakan yang dikembangkan oleh lembaga-lembaga Negara dan pejabat-pejabat 
pemerintah, namun demikian kebijakan tersebut menganut keterbukaan dan menyergap aspirasi masyarakat.

Pelaku kebijakan dalam mengimplementasikan kebijakan publik, harus sejalan dengan lingkungan kebijakan. Demikian pula kebijakan publik harus mampu menjawab berbagai permasalahan yang ada dilingkungan kebijakan. Namun yang tidak kalah pentingnya adalah lingkungan kebijakan harus mampu memberikan masukan berbagai kesulitan, hambatan, dan tantangan kepada pelaku kebijakan untuk mengimplementasikan kebijakan publik.

Kebijakan publik secara umum meliputi tiga langkah pokok, sebagaimana dikemukakan Mustopadidjaja (2002:25) yaitu “(1) perumusan kebijakan ; (2) pelaksanaan kebijakan ; (3) pengawasan dan penilaian pelaksanaan kebijakan”. Sedangkan menurut Nugroho (2008:74), ada tiga pokok yang berkenaan dengan kebijakan publik yaitu : "Perumusan Kebijakan, Implementasi Kebijakan, Evaluasi Kebijakan”.

Proses kebijakan publik, menurut Dye dalam Widodo (2009:16), yaitu bahwa "tahapan proses kebijakan publik meliputi identifikasi masalah, penyusunan agenda, perumusan kebijakan, pengesahan kebijakan, implementasi kebijakan dan evaluasi kebijakan ". Diantara tahapan tersebut semuanya tidak dapat dipisahkan.

Tahapan implementasi kebijakan seringkali dipandang tahapan ensensial, karena dirumuskan setelah secara nyata diimplementasikan. Implementasi kebijakan tersebut harus disertai dengan faktor pendukung sebagai persyaratan 
agar dapat berlangsung dengan efektif sebagai sarana pelaksanaan kerja. Atas dasar pemikiran tersebut, maka dimensi yang sangat menentukan pelaksanaan atau implementasi kebijakan adalah manajemen atau implementasi kebijakan dalam konteks manajemen berada didalam kerangka organizing, leading, controlling. Sebab itu, ketika kebijakan dibuat, maka tugas selanjutnya adalah mengoragnisasikan, melaksanakan kepemimpinan untuk memimpin pelaksanaan, dan melakukan pengendalian pelaksanaan tersebut. Secara jelas, kegiatan dalam manajemen implementasi kebijakan menurut Naihasy (2006:131-132), yaitu :

1. Implementasi strategis (pra implementasi) : menyesuaikan struktur dengan strategi, melembagakan strategi, mengoperasionalkan strategi, menggunakan prosedur untuk memudahkan implementasi.

2. Organizing (mengorganisasikan/pengorganisasian) : Desain organisasi dan struktur organisasi, pembagian pekerjaan dan desain pekerjaan, integrasi dan koordinasi serta perekrutan dan penetapan sumber daya manusia, hak wewenang dan kewajiban, pendelegasian (sentralisasi dan desentralisasi), pengembangan kapasitas organisasi dan kapasitas sumber daya manusia terhadap budaya organisasi.

3. Leading (pergerakan dan kepemimpinan) : efektivitas kepemimpinan, motivasi, etika mutu, kerjasama tim, komunikasi organisasi, dan negosiasi.

4. Controlling (pengendalian) : desain pengendalian, sistem informasi manajemen, pengendalian anggaran/keuangan dan audit.

Pendapat Naihasy tampak sekali tahapan dan rincian pekerjaan dalam implemtasi kebijakan. Namun tampak bahwa inti permasalahan dalam implementasi kebijakan adalah bagaimana kebijakan yang dibuat disesuaikan dengan sumberdaya yang tersedia. 
Kebijakan yang telah diformulasikan, selanjutnya dilakukan interprestasi untuk diimplementasikan, sebagaimana Wiliam dan Jones dalam Islamy, (2000:259), berpendapat sebagai berikut :

Masalah-masalah yang paling mendalam bagi penerapan kebijakan adalah hal yang memindahkan suatu keputusan kedalam kegiatan atau pengoperasian dengan cara tertentu, dan kegiatan atau pengoperasian dengan cara tertentu. Dan cara tersebut adalah bahwa apa yang dilakukan memiliki kemiripan nalar dengan keputusan tertentu, serta berfungsi dengan baik di dalam lingkup lembaga.

Implementasi kebijakan merupakan masalah yang kompleks menjadi masalah karena selalu terdapat kesenjangan antara penetapan kebijakan dengan pelaksanaanya. Menurut Grindle dalam Pasolong (2008:57), mengemukakan bahwa "keberhasilan atau kegagalan dari implemetasi kebijakan juga dipengaruhi oleh isi kebijakan (content of policy) dan konteks penerapan kebijakan (contex of implemtastion)". Kemudian diungkapkan bahwa implementasi adalah suatu kegiatan untuk mengoperasikan sebuah program. Pilar-pilar untuk melaksanakan program sebagaimana dikemukakan Jones yang dibahas oleh Gafftar dalam Widodo (2009:89), yaitu :

1. Pengorganisasi (organization) : Merupakan suatu upaya untuk menetapkan dan menata kembali sumber daya, unit-unit, dan metode-metode yang mengarah pada mewujudkan kebijakan menjadi hasil sesuai dengan apa yang menjadi tujuan dan sasaran kebijakan,

2. Interprestasi (interpretation) : merupakan aktivitas interprestasi (penjelasan) substansi dari suatu kebijakandalam bahasa yang lebih operasional dan mudah dipahami sehingga dapat dilaksanakan dan diterima oleh para pelaku dan sasaran kebijakan,

3. Aplikasi (Aplication) : merupakan aktivitas penyediaan pelayanan secara rutin, pembayaran atau lainnya sesuai dengan tujuan dan sarana kebijakan yang ada. 
Implementasi kebijakan merupakan aktifitas praktis yang mengarah pada pemilihan tindakan dan pengamatan sampai selesainya waktu pelaksanaan kebijakan yang bersangkutan.

Faktor-faktor yang menentukan dan mempengaruhi implementsi kebijakan itu tergantung kepada sumber daya manusia, modal, logistik, partisipasi, wewenang serta informasi". Definisi dari implementasi kebijakan menurut Mazmanian dan Sabatier dalam Wahab. (2004:68), yaitu :

Implementasi adalah pelaksanaan keputusan dasar, bisanya dalam bentuk undang-undang, namun dapat pula berbentuk perintah-perintah atau keputusan eksekutif yang penting atau keputusan badan peradilan. Lazimnya, keputusan tersebut mengindentifikasikan masalah yang inggin diatasi, menyebutkan secara tegas, tujuan/sasaran yang inggin dicapai dan berbagai cara untuk menstrukturkan/mengatur proses implementasinya. Proses ini berlangsung setelah melalui sejumlah tahapan pengesahan Undang-Undang, kemudian ouput kebijakan dalam bentuk pelaksanaan keputusan badan (instansi) pelaksanaan, kesediaan dilaksanakannya keputusan-keputusan tersebut oleh kelompok-kelompok sasaran, dampak nyata baik yang dikehendakatau yang tidak dari ouput tersebut, dampak keputusan sebagai dipersepsikan oleh badan-badan yang mengambil keputusan, dan akhirnya perbaikan-perbaikan penting atau upaya untuk melakukan perbaikan-perbaikan terhadap Undang-Undang/peraturan yang bersangkutan.

Selanjutnya implementasi kebijakan menurut Horn dalam Wibawa (1994:19), yaitu :

Kebijakan yang sudah kongkrit dan jelas, selain berisikan tujuan atau sasaran yang akan dicapai. Juga merinci tentang alokasi dan personil sumber daya lian, prosedur kerja yang harus ditunjuk guna tercapainya sasaran atau tujuan kebijakan artinya kebijakan tersebut harus sudah bersifat operasional oleh karena itu kebijakan harus membuat standard 
dan tujuan yang jelas, spesifikasi dan tugas yang harus dicapai oleh para pelaksana kebijakan tersebut.

Peran kebijakan dalam penataan dan pengaturan suatu objek tidak hanya untuk implementasinya saja, melainkan harus berperan sebagai sumber standard dalam penilaian dan pengendalian kebijakan, sebagaimana dikemukan Hinggis dalam Pasolong (2008:57), yaitu "Implementasi kebijakan sebagai rangkuman dari berbagai kegiatan yang di dalamnya sumber daya manusia menggunakan sumber daya lain untuk mencapai sasaran strategis". Sedangkan Edwards dalam Tachjan (2008:25), yaitu mengemukakan bahwa : "Policy implementation,...is the stage of policy making betwen the establisment of a policy... and the consequences of the policy for the people whom it affects".

Faktor-faktor yang mempengaruhi terhadap kebijakan menurut Edward III dalam Indiahono (2009:47-51), yaitu "komunikasi (communication), sumber daya (resources), disposisi (dispostions) dan struktur Birokrasi (bureaucratic structure)". Dapat digambarkan model implementsi kebijakan menurut Edward III sebagai berikut : 


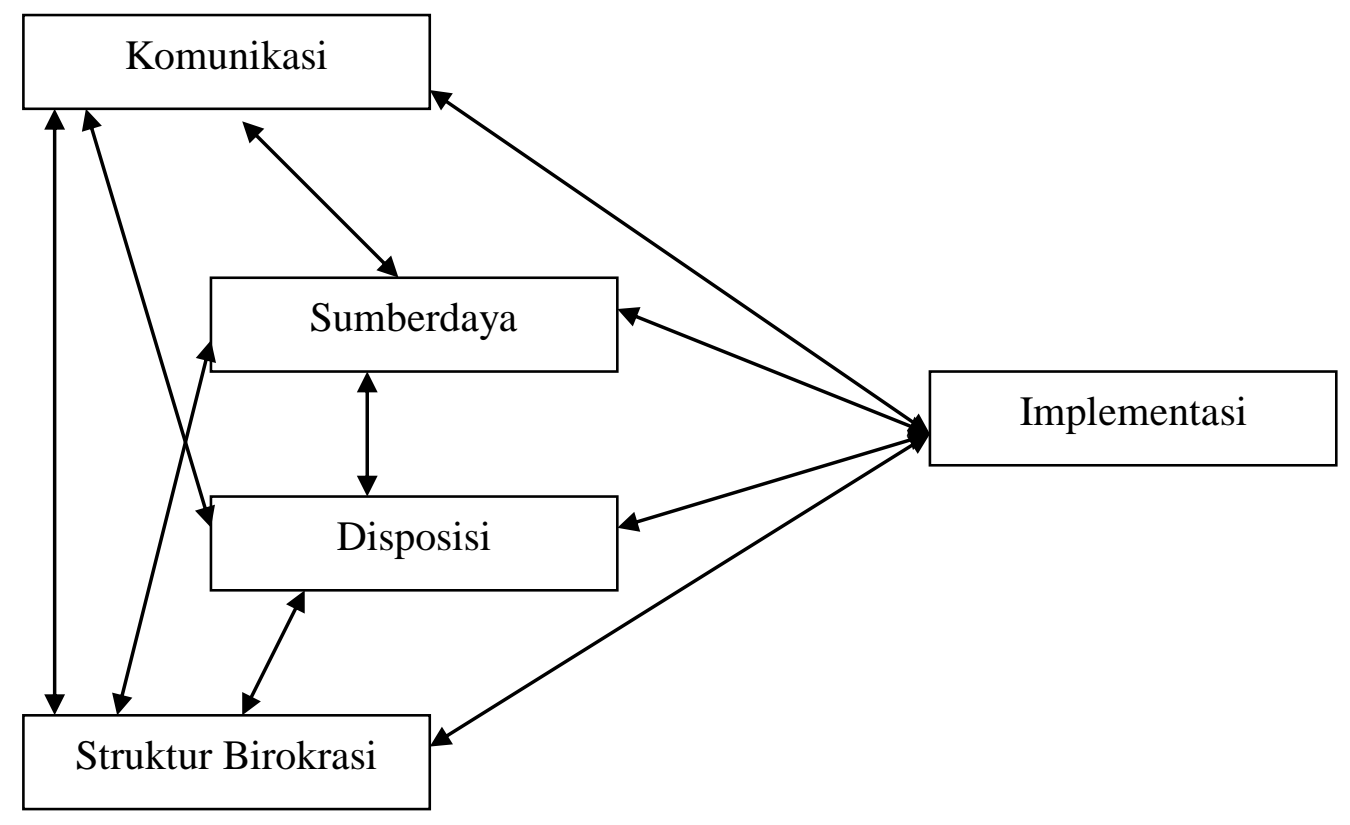

Gambar 2.1

Model Implementasi Kebijakan

Sumber : Edward III dalam Indiahono (2009:51)

Model Implementasi kebijakan dari gambar tersebut diatas akan dijelaskan

lebih detailnya mengenai faktor-faktor kebijakan menurut Edward III dalam

Indiahono (2009:47-51), yaitu :

1. Komunikasi

Menunjukan bahwa setiap kebijakan akan dapat dilaksanakan dengan baik jiak terjadi komunikasi efektif anatar pelaksana program (kebijakan) dengan para kelompok sasaran(target group). Tujuan dan sasaran dari program/kebijakan dapat disosialisaikan secara baik sehingga dapat menghindari adanya distorsi atas kebijakan dan program. Ini menjadi penting karena semakin tinggi pengetahuan kelompok sasaran atas program maka akan menurangi tingkat penolakan dan kekekliruan dalam aplikasi program dan kebijakan dalam ranah yang sesungguhnya.

2. Sumber daya

Menunjukan setiap kebijakan harus didukung oleh sumber daya yang memadai, baik sumber daya manusia maupun sumber daya finansial. Sumber daya manusia adalah kecukupan baik kualitas 
maupun kuantitas implementor yang dapat melingkupi seluruh kelompok sasaran. Sumber daya finansial adalah kecukupan modal investasi atas sebuha program/kebijakan. Keduanya harus diperhatikan dalam implementasi program/kebijakan pemerintah. Sebab tanpa kehandalan implementor, kebijakan menjadi kurang enerjik dan berjalan lamabt dan seadanya. Sedangkan, sumber daya finansial menjamin keberlamngsungan program/kebijakan. Tanpa ada dukungan finansial yang memadai, program tak dapat berjalan efektif dan cepat dlam mencapai tujuan dan sasaran.

3. Disposisi

Menunjukan karakteristik yang menenmpel erat kepada implementor kebijakan/program. Krakter yng penting dimiliki oleh implementor adalah kejujuran, komitmen dan demokratis. Implementor yang memiliki komitmen tinggi dan jujur akan senantias bertahan di antara hambatan yang ditemui dalam program/kebijakan. Kejujuran mengarahkan implemntor untuk tetap berada pada aras progrma yang telah digariskan dalam guideline program. Komitmen dan kejujuran membawanya semakian antusias dalam melaksnakan tahap-tahap program secara konsisten. Sikap yang demokratis akan meningkatkan kesan baik implementor dan kebijakan dihadapan anggota kelompok sasaran. Sikap ini akan menurunkan resistensi dari masyarakat dan menumbuhkan rasa percaya dan kepedulian kelompok sasaran terhadap implementor dan program/kebijakan.

4. Struktur Birokrasi

Menunjukan bahwa struktur birokrasi menajdi birokrasi dalam implementasi kebijakan. Aspek struktur birokrasi ini mencakup dau hal penting pertam adalah mekanisme, dan strukutr organisasi pelaksana sendiri. Mekanisme implemetasi program biasanya sudah ditetapkan melalui standar operating prosedur (SOP) yang dicantumkan dalam guideline program/kebijakan. SOP yang baik tercantum kerangka kerja yang jelas, sistematis, tidak berbelit dan mudah dipahami oleh siapun karena akan menjadi acuan dalam bekerjanya implementor. Sedangkan struktur organisasi pelaksana pun sejauh mungkin menghindari hal yang berbelit, panjang dan kompleks. Struktur organisasi pelaksana harus dapat menajmin adanya pengambilan keputusan atas luas bias dalam program secara tepat. Dan hal ini hanya dapat lahir jika struktur didesain secara ringkas dan fleksibel menghindari "birus weberian" yang kaku, terlau hirarki dan birokratis. 
Pendapat Edward III dalam Indiahono (2009:47-51), menunjukkan bahwa aspek-aspek itu akan berpengaruh terhadap kesuksesan pelaksanaan kebijakan, karena terdapat kesuksesan pelaksanaan kebijakan. Aspek komunikasi dan birokrasi mendekati dengan informasi dan pembagian potensi dukungan kebijakan. Selanjutnya agar implementasi kebijakan pemerintah berhasil, harus memperhatikan faktor-faktor yang mempengaruhinya, Keempat variabel atau faktor-faktor tersebut di atas dalam model yang dibangun oleh Edward memiliki keterkaitan satu dengan yang lain dalam mencapai tujuan dan sasaran program/kebijakan. Semuanya selain bersinergi dalam mencapai tujuan dan satu faktor/variabel akan saling mempengaruhi faktor/variabel yang lain. Misalnya saja, implementor yang tidak jujur akan mudah sekali melakukan "mark up" dan korupsi atas dana program/kebijakan dan program tidak dapat optimal dalam mencapai tujuannya. Begitupun ketika watak dari implementor kurang demokratis akan sangat memperangaruhi proses komunikasi dengan kelompok sasaran.

\subsubsection{Konsep Kinerja Pegawai}

Kinerja merupakan kemampuan pegawai dalam melaksanakan tugas kerjanya didalam organisasi atau instansi secara optimal. Kinerja pegawai merupakan kemampuan dimana individu-individu atau kelompok/tim pegawai didalam organisasi dapat melaksanakan kerjanya sesuai dengan tujuan dan sasaran yang diharapkan atau direncanakan sebelumnya.

Menurut Prawirosentono dalam Pasolong (2008:176) mengatakan bahwa kinerja yaitu sebagai berikut : 
Kinerja adalah hasil kerja yang dapat dicapai oleh pegawai atau kelompok pegawai dalam suatu organisasi, sesuai dengan wewenang dan tanggungjawab masing-masing, dalam upaya mencapai tujuan organisasi bersangkutan secara legal, tidak melanggar hukum dan sesuai dengan moral dan etika.

Pengertian di atas yang dikemukan oleh Prawirosentono, dapat dilihat bahwa kinerja adalah suatu hasil yang dicapai seseorang dalam melaksanakan tugas-tugas yang dibebankan kepadanya yang didasarkan atas sesuai dengan wewenang, tanggung jawab individual dalam mencapai tujuan organisasi. Ini berarti suatu kinerja adalah kemampuan dan minat seseorang pekerja, sesuai dengan wewenang serta tanggungjawabnya untuk mencapai tujuan organisasi, semakin tinggi wewenang dan tanggung jawabnya, maka semakin besarlah kinerja pegawai yang bersangkutan, dan untuk melaksanakan tujuan organisasi itu harus diiiringi dengan hukum atau tidak melanggar hukum, sesuai dengan moral dan etika.

Pendapat Widodo dalam Pasolong (2008:175), “Kinerja adalah melakukan suatu kegiatan dan menyempurnakanya sesuai dengan tanggungjawabnya dengan hasil yang diharapkan”. Namun menurut LAN-RI dalam Pasolong (2008:175176), merumuskan bahwa kinerja pegawai adalah : "Kinerja merupakan gambaran mengenai tingkat pencapaian pelaksanaan suatu kegiatan, program, kebijaksanaan dalam mewujudkan sasaran, tujuan, misi dan visi organisasi”.

Kinerja pegawai bila dikaitan dengan kinerja organisasi menurut Nasucha dalam Pasolong (2008:177), yaitu : 
Kinerja pegawai sebagai efektivitas organisasi secara menyuruh untuk memenuhi kebutuhan yang ditetapkan dari setiap kelompok yang berkenaan melalui usaha-usaha yang sistematik dan meningkatkan kemampuan organisasi secara terus menerus mencapai kebutuhanya secara efektif.

Definisi atau pengertian tentang kinerja yang dikemukakan oleh Widodo, LAN-RI dan Nasucha, dapat dijelaskan bahwa kinerja mempunyai beberapa elemen yaitu :

1. Hasil kerja dicapai secara individual atau secara institusi, yang berarti kinerja tersebut adalah hasil akhir yang diperloleh secara sendiri-sendiri atau kelompok.

2. Dalam melaksanakan tugas, orang atau lembaga diberikan wewenang dan tanggungjawab, yang berarti orang atau lembaga diberikan dan kekuasaan untuk ditindaklanjuti, sehingga pekerjannya dapat dilakukan dengan efesien dan efektif.

3. Pekerjaan haruslah dilakukan secara legal, yang berarti dalam melaksanakan tugas individu atau lembaga tentu saja harus mengikuti aturan yang telah ditetapkan.

4. Pekerjaan tidaklah bertentangan dengan moral atau etika, artinya selain mengikuti aturan yang telah ditetapkan, tentu saja pekerjaan tersebut haruslah sesuai moral dan etika yang berlaku umum.

Kinerja pegawai merupakan kemampuan pegawai didalam organisasi dapat melaksanakan kerjanya sesuai dengan tujuan dan sasaran yang diharapkan 
atau direncanakan sebelumnya. Di dalam proses pelaksanaan aktivitas harus selalu dilakukan monitoring, penilaian, dan review atau peninjauan ulang terhadap kinerja. Melalui monitoring, dilakukan pengukuran dan penilaian kinerja dilakukan prediksi apakah terjadi deviasi pelaksanaan terhadap rencana yang dapat menganggu pencapaian tujuan. Atas dasar penilain tersebut, dilakukan riview untuk mengetahui apakah terdapat kesalahan dalam proses kinerja.

Kinerja dapat diartikan sebagai gambaran mengenai tingkat pencapaian pelaksanaan suatu kegiatan atau program atau kebijakan dalam mewujudkan sasaran, tujuan, misi dan visi organisasi yang tertuang dalam rencana strategi suatu organisasi. Namun ada beberapa faktor yang mempengaruhi kinerja, antara lain dikemukakan menurut Armstrong dan Baron dalam Widodo (2007:99) yaitu sebagai berikut :

1. Personal Facktors, ditunjukan oleh tingkat keterampilan, kompetisi yang dimiliki, motivasi, dan komitmen individu.

2. Leadership factors, ditentukan oleh kualitas dorongan, bimbingan, dan dukungan yang dilakukan manajer dan team leader.

3. Team factors, ditunjukan oleh kualitas dukungan yang diberikan oleh rekan sekerja.

4. Sytem factors, ditunjukan oleh adanya sistem kerja dan fasilitas yang diberikan organisasi.

5. Contextual/situational factors, ditunjukan oleh tingginya tingkat tekanan dan perubahan lingkungan internal dan eksternal.

Menurut Atkinson dalam Widodo (2007:99) bahwa "kinerja merupakan fungsi motivasi dan kemampuan, dirumusakn model persamaan kinerja $=f$ 
(motivasi, kemapuan)”. Sementara itu Porter dan Lawler dalam Widodo (2007:99100) berpendapat bahwa sebagai berikut :

Kinerja merupakan fungsi keiinginan melakukan pekerjaan, keterampilan yang perlu untuk menyelesaikan tugas, pemahaman yang jelas atas apa yang dikerjakan dan bagaiman mengerjakanya, dirumuskan model persamaan kinerja $=f$ (keinginan melakukan pekerjaan, keterampilan, pemahaman apa dan bagaimana melakukan).

Lorsch dan Laurence dalam Widodo (2007:100) menggunanakan bahwa pemahaman bahwa "kinerja adalah fungsi atribut individu, organisasi, dan lingkungan sehingga dirumuskan model persamaan kinerja $=f$ (atribut individu, organisasi, lingkungan)". Berdasarkan pendapat diatas, kemudian dirumuskan oleh Harsey dan Blanchard dalam Widodo (2007:100) mengemukakan yaitu sebagai berikut :

Ada tujuh faktor kinerja yang mempengaruhi kinerja dan dirumuskan dengan The ACHIEVE Model, A - Ability (knowledge dan skill), C Clarity (understanding dan role perception), $\mathrm{H}-$ Help (organisational support), I - Incentive (motivation atau willingness), E - Evaluation (coaching dan performance feedback), V - Validity (valid dan legal personnel praktices), E-Environment (environmental fit).

Pelaksanaan kinerja sangat dipengaruhi oleh beberapa faktor baik yang bersumber dari pekerjaan sendiri maupun yang bersumber dari organisasi. Dari pekerjaan dipengaruhi oleh kemampuan atau kompetensinya. Sementara itu, dari segi organisasi dipengaruhi seberapa baik pemimpin memberdayakan pekerjanya, bagaimana mereka memberikan penghargaan pada pekerja, dan bagaimana 
mereka membantu meningkatkan kemampuan kinerja pekerja melalui coaching, mentoringI, dan counselling.

Pengukuran kinerja berkaitan dengan hasil yang dapat dikuantitatifkan dan mengusahakan data setelah kejadian. Pengukuran kinerja pada dasarnya digunakan untuk penilaian atas keberhasilan atau kegagalan pelaksanaan kegiatan, program dan atau kebijakan sesuai dengan sasaran dengan sasaran dan tujuan yang telah ditetapkan dalam rangka mewujudkan misi dan visi instansi pemerintah. Pengukuran kinerja mencakup penetapan indikator kinerja dan penetapan pencapaian indikator kinerja.

Penilaian kinerja merupakan evaluasi keberhasilan atau kegagalan seseorang dalam menjalankan tugasnya. Jika penilaian kinerja terhadap birokrasi, berarti evaluasi keberhasilan atau kegagalan birokrasi dalam menjalankan tugasnya sebagai pelayan masyarakat. Dessler dalam Pasolong (2008:182), menyatakan bahwa sebagi berikut :

Penilaian kinerja adalah merupakan upaya sistematis untuk membandingkan apa yang dicapai seseorang dibandingkan dengan standar yang ada. Tujuannya, yaitu untuk mendorong kinerja seseorang agar bisa berada diatas rata-rata.

Penilaian dan pengukuran terhadap kinerja perlu dilakukan untuk mengetahui apakah selama pelaksanaan kinerja terdapat deviasi dari rencan yang telah ditentukan, atau apakah kinerja dapat dilakukan sesuai jadwal waktu yang ditentukan, atau apakah hasil kinerja telah tercapai sesuai dengan yang 
diharapkan. Pengukuran kinerja yang tepat dengan beberapa cara Menurut Widodo (2007:344), yaitu sebagai berikut :

1. memastikan persyaratan yang diinginkan pelanggan telah terpenuhi,

2. mengusahakan standar kinerja untuk menciptakan perbandingan,

3. mengusahakan jarak bagi orang untuk memonitoring tingkat kinerja,

4. menetapkan arti penting masalah kualitas dan menentukan apa yang perlu diprioritaskan perhatian,

5. menghindari konsenkuensi dan rendahnya kualitas,

6. mempertimbangkan penggunaan sumber daya,

7. mengusahakan umpan balik untuk mendorong perbaikan.

Namun selain itu Keban (1995:109), mengatakan bahwa "pengukuran kinerja harus dilihat dari sebagai upaya yang sangat berharga bagi profesionalisasi di institusi pelayanan publik". Lebih jelasnya bahwa dengan mengatahui kelemahan dan kelebihan, hambatan dan dorongan atau berbagai faktor sukses bagi kinerja pegawai atau institusi, maka terbukalah jalan menuju profesionalisasi, yaitu memperbaiki kesalahan-kesalahan yang dilakukan selama ini.

Menurut Dwiyanto dalam Pasolong (2008:182), mengemukakan bahwa penilaian kinerja, yaitu "Penilaian kinerja merupakan suatu kegiatan yang sangat penting sebagai ukuran keberhasilan suatu organisasi dalam mencapai misinya”. Maksudnya adalah bahwa teoritik penilaian kinerja sangat erat kaitannya dengan analis pekerjaan. Artinya, suatu penilain tidak dapat dilakukan jika masih terdapat ketidakjelasan tentang pekerjaan itu sendiri, yang merupakan sumber daya manusia, sehingga dapat dikatan bahwa efektivitas penilaian kinerja sangat 
tergantung kepada baik buruknya manajemen sumber daya manusia yang dimiliki. Sebenarnya banyak faktor yang dapat dijadikan ukuran kinerja, namun ukuran kinerja harus relevan, signifikan, dan komprehensif. Faktor-faktor yang menentukan kinerja menurut Widodo (2007:350) mengemukakan yaitu antara lain

: “(a) Produktivitas, (b) Kualitas, (c) Ketepatan Waktu, (c) Cyle Time, (d) Pemanfaatan Sumber Daya, (e) Biaya”.

\subsection{Kerangka Pemikiran}

Implementasi kebijakan menurut Dunn (2000:132), mengemukakan implementasi kebijakan yaitu adalah : "Pelaksanaan pengendalian aksi-aksi kebijakan di dalam kurun waktu tertentu". implementasi kebijakan merupakan aktifitas praktis yang mengarah pada pemilihan tindakan dan pengamatan sampai selesainya waktu pelaksanaan kebijakan yang bersangkutan. Implementasi kebijakan dibedakan dari formulasi kebijakan yang dapat dipandang sebagai tahapan yang bersifat teoritis. Implementasi kebijakan Publik merupakan proses kegiatan administratif yang dilakukan setelah kebijakan ditetapkan/disetujui.

Implementasi kebijakan sangat menentukan apakah organisasi akan berhasil atau gagal untuk mencapai tujuan sasaran yang telah digariskan dalam kebijakan tersebut sebelumnya. Oleh karena itu implementasi kebijakan berkaitan erat dengan waktu tertetnu dalam pelaksanaanya, dengan kata lain adanya target yang diarahkan untuk dilaksanakan.

Proses implementasi suatu kebijakan dibutuhkan adanya komponen implementasi kebijakan yaitu unsur pelaksana, program dan kelompok sasaran. 
Unsur pelaksana adalah orang-orang yang berkewajiban untuk melakukan tindakan dan menggunakan saran bagi tercapainya tujuan suatu kebijakan, yang dapat berbentuk organisasi pemerintah. Pihak yang terutama mempunyai kewajiban untuk melaksanakan kebijakan Publik adalah unit-unit administratif atau unit-unit birokratik. Unit-unit administratif atau unit-unit birokratik ini berfungsi sebagai wahana melalui dan dalam hal mana berbagai kegiatan administratif yang bertalian dengan proses kebijakan Publik dilakukan. Dalam implementasi kebijakan ia memiliki diskresi menganai intrumen apa yang paling tepat untuk digunakan. Berdasarkan otoritas dan kapasitas administratif yang dimilikinya ia melakukan berbagai tindakan, mulai dari penentuan tujuan dan sasaran orgnisasional, analisis serta permusan kebijakan dan strategi organisasi, pengambilan keputusan, perencanaan, penyusunan program, pengoranisasian, penggerakan manusia, pelaksanaan kegiatan operasional, pengawasan dan penilaian.

Program merupakan rencana yang bersifat komprehensif yang sudah menggambarkan sumber daya yang akan digunakan dan terpadu dalam satu kesatuan. Program tersebut menggambarkan sasaran, kebijakan, prosedeur, metoda, standar dan budget. Isi program harus menggambarkan volume (bobot) pekerjaan dan sumber dayanya, isi program harus jelas dan dapat dipahami dengan mudah oleh pelaksana atau dengan kata lain program dapat menggambarkan atau mencerminkan secara menyeruh mengenai arah, strategi dan sasaran yang ditempuh oleh setiap unit administratif dalam memecahkan masalah- 
masalah yang berkembang serta tujuan-tujuan dan sasaran-sasaran yang hendak dicapai.

Kelompok sasaran (target group), yaitu sekelompok orang atau organisasi dalam masyarakat yang akan meneriman barang dan jasa atau yang akan dipengaruhi perilakunya oleh kebijakan. Dengan begitu, mereka dapat mengetahui hak-hak yang akan mereka terima dan kewajiban yang semestinya dilakukan. Dalam hal ini faktor-faktor yang mempengaruhi terhadap kebijakan menurut Van Meter dan Van Horn dalam Tachjan (2008:39-40), yaitu sebagai berikut :

1. Standar dan sasaran kebijakan, standar dan sasaran kebijakan pada dasarnya adalah apa yang hendak dicapai oleh program atau kebijakan, baik yang berwujud oleh program atau kebijakan, baik yang berwujud maupun tidak, jangka pendek, menengah, atau panjang. Kejelasan dan sasaran kebijakan harus dapat dilihat secara spesifik sehingga di akhir program dapat diketahui keberhasilan atau kegagalan dari kebijakan atau program yang dijalankan.

2. Sumber daya menunjukan lepada seberapa besar dukungan dan sumber daya manusia untuk melaksanakan program atau kebijakan. Hal sulit yang terjadi adalah berapa nilai sumber daya (baik finansial maupun manusia) untuk menghasilkan implementasi kebijakan dengan kinerja baik. Evaluasi program atau kebijakan seharusnya dapat menjelaskan nilai yang efesien.

3. Karakteristik organisasi pelaksana, menunjuk seberapa besar daya dukung struktur organisasi/ struktur birokrasi, nilai-nilai yang berkembang, hubungan dan komunikasi yang terjadi di internal birokrasi.

4. Komunikasi antar organisasi pelaksana dan kegiatan-kegiatan pelaksanaan, menunjukan kepada mekanisme prosedur yang dirancangkan untuk mencapai sasaran dan tujuan program. Komunikasi ini harus ditetapkan sebagai acuan, misalnya: seberapa sering rapat rutin akan diadakan, tempat dan waktu. Komunikasi antar organisasi juga menunjuk adanya tuntutan saling dukung antar institusi yang berkaitan dengan program atau kebijakan dan kelompok sasaran mampu memahami dan bertanggung jawab atas program yang dijalankan dalam pelaksanaan kegiatan-kegiatan.

5. Sikap para pelaksana, menunjuk bahwa sikap para pelaksana menjadi variabel penting dalam implementasi kebijakan. Seberapa 
demokkratis, antusias, dan responsif terhadap kelompok sasaran dan lingkungan beberapa yang dapat ditunjuk sebagai bagian dari sikap pelaksana ini.

6. Lingkungan sosial, ekonomi dan politik, menunjuk bahwa lingkungan dalam ranah implementasi dapat mempengaruhi kesuksesan implementasi kebijakan itu sendiri.

Penulis telah menjelaskan diatas mengenai teori implementasi kebijakan dan alat analisis atau alat ukur implementasi kebijakan yaitu faktor-faktor yang mempengaruhi kebijakan publik, selanjutnya penulis akan mengemukakan tentang pengertian kinerja pegawai menurut Mangkunegara (2003:67), yaitu mengemukakan bahwa kinerja adalah "Kinerja merupakan hasil kerja secara kualitas dan kuantitas yang dicapai oleh seseorang dalam melaksanakan fungsinya sesuai dengan tanggung jawab yang diberikan kepadanya".

Kinerja pegawai dalam melaksanakan tugasnya untuk mencapai sasaran dan waktu yang telah ditetapkan tanpa menghiraukan jumlah biaya, tenaga dan alat-alat yang telah dipergunakan sesuai yang dimilikinya sehingga untuk mendapatkan kejelasan pelaksanaan implementasi kebijakan tersebut.

Pengukuran kinerja merupakan salah satu faktor penting dalam meningkatkan daya saing sebuah organisasi. Rancangan sistem pengukuran kinerja yang akurat dan kontekstual merupakan jembatan emas kearah mana keunggulan sebuah organisasi akan dibawa. Sehubungan dalam hal tersebut Menurut Mangkunegara (2003:75), mendefinisikan kedalam empat dimensi kinerja pegawai, yaitu : 
1. Kualitas Kerja yang dimaksud meliputi ketepatan, ketelitian, keterampilan serta keberhasilan.

2. Kuantitas kerja yang meliputi Output rutin serta output non rutin atau ekstra.

3. Keandalan atau dapat tidaknya diandalkan yakni dapat tidaknya mengiktui instruksi, kemampuan, inisiatif, kehati-hatian serta kerajinan,

4. Sikap yang meliputi sikap terhadap perusahaan, pegawai lain, terhadap pekerjaan serta kerjasama.

Apabila pengertian implementasi kebijakan dihubungkan dengan kinerja pegawai maka dapat diperoleh kesimpulan yang menjelaskan implementasi kebijakan memiliki pengaruh yang sangat besar terhadap kinerja pegawai. Sebagaimana dikemukan oleh pendapat menurut Van Meter dan Van Horn dalam Wahab (2004:78-79), yaitu :

Bahwa perbedaan-perbedaan dalam proses implementasi akan dipengaruhi oleh sifat kebijakan yang akan dilaksanakan. Selanjutnya mereka menawarkan suatu pendekatan yang mencoba untuk menghubungkan antara isu kebijakan dengan implementasi dan suatu model konseptual yang mempertalikan kebijakan dengan performance.

Bertitik tolak pada kerangka pemikiran di atas, maka dapat digambarkan paradigma pemikiran penelitian ini sebagai berikut : 


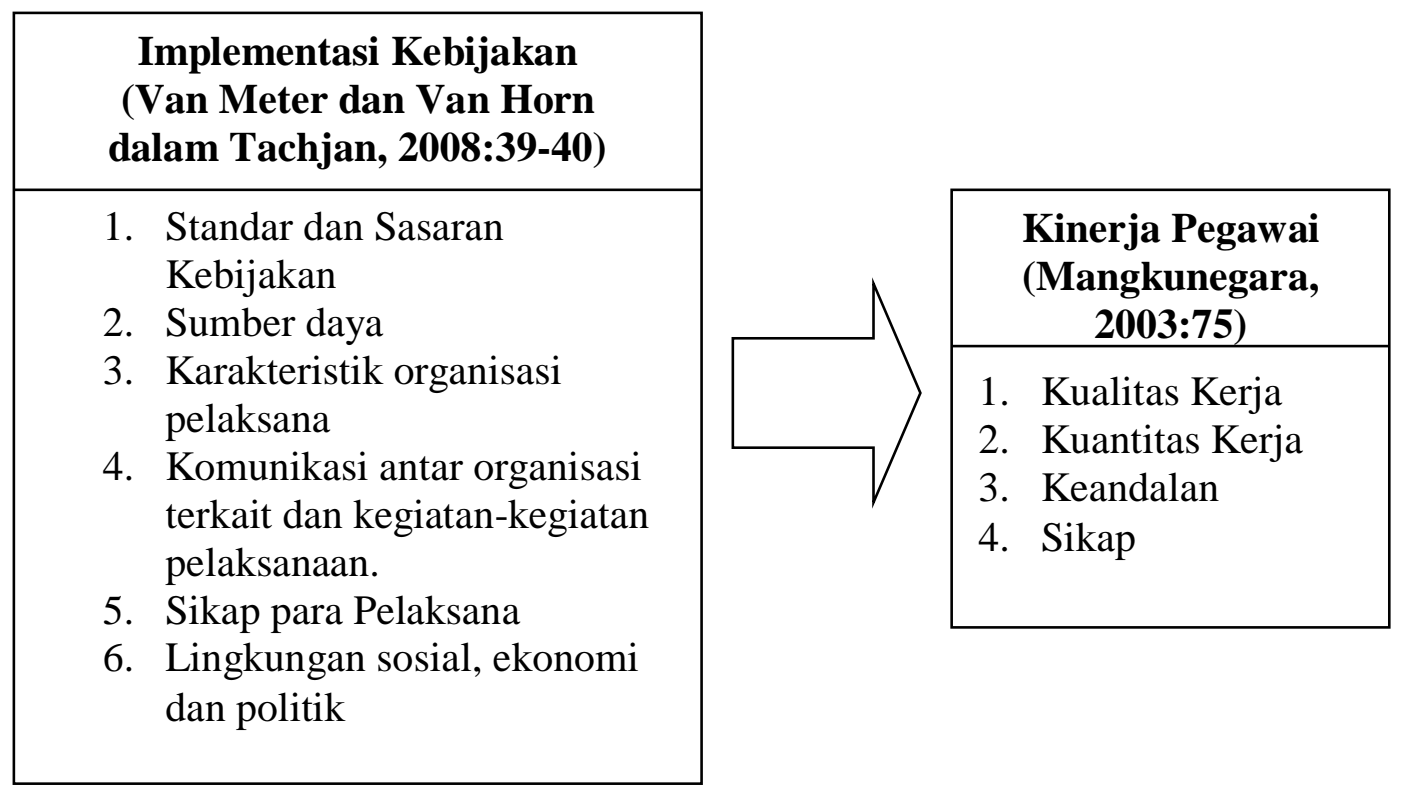

Gambar 2.2

Paradigma Pemikiran Penelitian

\subsection{Hipotesis}

Berdasarkan kerangka pemikiran di atas, maka peneliti merumuskan hipotesis sebagai berikut :

1. Implementasi kebijakan besar pengaruhnya terhadap kinerja pegawai pada Kantor Satuan Polisi Pamong Praja Kabupaten Subang.

2. Implementasi kebijakan melalui faktor Standar dan Sasaran Kebijakan, Sumber daya, Karakteristik organisasi pelaksana, Komunikasi antar organisasi pelaksana dan kegiatan-kegiatan pelaksanaan, Sikap para pelaksana, Lingkungan sosial ekonomi dan politik, besar pengaruhnya terhadap kinerja pegawai pada Kantor Satuan Polisi Pamong Praja Kabupaten Subang. 


\section{BAB III}

\section{OBYEK DAN METODE PENELITIAN}

\subsection{Obyek Penelitian}

Objek dalam penelitian ini adalah Para Pegawai Satuan Polisi Pamong Praja Kabupaten Subang. Untuk lebih jelasnya penulis menguraikannya sebagai berikut:

\subsubsection{Visi dan Misi Satuan Polisi Pamong Praja}

Visi dan Misi Satuan Polisi Pamong Praja adalah sebagai berikut :

1. Visi

“Terwujudnya Satuan Polisi Pamong Praja yang handal dan profesional dalam bidang Trantibum dan Penegakan Perda, dalam menunjang Pembangunan Subang yang Berbasis Gotong Royong”.

2. Misi

a. Meningkatkan kualitas dan kuantitas sumber daya Non Aparatur sesuai kebutuhan Satuan Polisi Pamong Praja,

b. Menciptakan masyarakat yang tertib dengan mendorong peran serta masyarakat dan segenap Stake Holdert,

c. Mewujudkan ketaatan masyarakat terhadap Perda / Keputusan dan Kebijakan Bupati, 
d. Mewujudkan ketersediaan sarana dan prasarana Trantibum dan Penegakan Perda dengan mendorong peran serta masyarakat dan segenap Stake Holdert

e. Mewujudkan Trantib dan Penegakan Perda Sebagai sektor pendukung keberdayaan masyarakat Kabupaten Subang.

\subsubsection{Kedudukan, Tugas Pokok dan Fungsi Satuan Polisi Pamong Praja}

Kedudukan, Tugas Pokok dan Fungsi Satuan Polisi Pamong Praja telah diatur oleh Keputusan Bupati Subang Nomor 14D.12 Tahun 2008, Sebagaimana yang dimaksud dapat dijelaskan sebagai berikut :

1. Kedudukan Satuan Polisi Pamong Praja

a. Satuan merupakan unsur penunjang Pemerintah Daerah dalam Pembinaan Ketenteraman dan Ketertiban;

b. Satuan dipimpin oleh seorang Kepala Satuan yang berada di bawah dan bertanggungjawab kepada Bupati.

2. Tugas Pokok Satuan Polisi Pamong Praja

Satuan mempunyai tugas pokok melaksanakan pembinaan Ketenteraman dan Ketertiban dalam rangka mendukung penyelenggaraan tugas-tugas Pemerintah Daerah.

3. Fungsi Satuan Polisi Pamong Praja

Untuk menyelenggarakan tugas pokok Satuan Polisi Pamong Praja mempunyai fungsi : 
a. Perumusan kebijaksanaan teknis dibidang Ketenteraman dan Ketertiban, Penegakan Peraturan Daerah, Keputusan Kepala Daerah serta Pengendalian Operasional;

b. Penyusunan program penyuluhan kepada masyarakat dalam rangka penegakan Ketenteraman dan Ketertiban, Penegakan Peraturan Daerah serta Keputusan Kepala Daerah;

c. Pelaksanaan pembinaan personil dan peningkatan kualitas Polisi Pamong Praja dalam melaksanakan tugas operasional;

d. Penyusunan prosedur tetap operasional dan pengendalian Ketenteraman dan Ketertiban, Penegakan Peraturan Daerah serta Keputusan Kepala Daerah;

e. Pelaksanaan evaluasi terhadap Ketenteraman dan Ketertiban, Penegakan Peraturan Daerah serta Keputusan Kepala Daerah;

f. Penyelenggaraan Teknis Administratif Ketatausahaan.

\subsubsection{Susunan Organisasi dan Tata Kerja Satuan Polisi Pamong Praja}

Susunan organisasi dan Tata kerj Satuan Polisi Pamong Praja Kabupaten Subang dibentuk berdasarkan Peraturan Daerah Kabupaten Subang Nomor 14D. 12 Tahun 2008 Pasal 6 Ayat 1 yaitu :

(1) Susunan Organisasi Satuan terdiri atas :
a. Kepala
b. Sub Bagian Tata Usaha
c. Seksi Ketentraman dan Ketertiban 
d. Seksi Pengendalalian Operasional

e. Seksi Penegakan

f. Kelompok Jabatan Fungsional

Adapun uraian penjelasan tugas dari masing-masing satuan organisasi Satuan Polisi Pamong Praja adalah sebagai berikut :

1. Kepala

Tugas pokoknya memimpin mengkoordinasikan dan mengendalikan Kantor dalam melaksanakan urusan rumah tangga Daerah di bidang pembinaan ketentraman dan ketertiban.

2. Sub Bagian Tata Usaha

1. Sub Bagian Tata Usaha mempunyai tugas pokok melaksanakan pengelolaan urusan umum, perlengkapan, keuangan, kepegawaian, dan pelaporan

2. Untuk menyelenggarakan tugas pokok sebagaimana dimaksud pada ayat (1) dalam Pasal ini, Sub Bagian Tata Usaha mempunyai Fungsi :

a. Perumusan pelaksanaan administrasi umum, perlengkapan, keuangan kepegawaian dan pelaporan

b. Pemberian pelayanan teknis administratif bagi seluruh satuan organisasi dalam lingkungan Kantor

c. Penyusunan dan penyiapan pedoman dan petunjuk tatalaksana administrasi umum 
d. Penyusunan dan penyiapan rencana anggaran rutin dan pembangunan Kantor

e. Pengumpulan, penyusunan dan penyajian data informasi dibidang kearsipan

f. Pengelolaan dan bimbingan administrasi kepegawaian, keuangan, peralatan dan perbekalan di lingkungan Kantor

g. Penyelenggaraan urusan rumah tangga Kantor, perjalanan dinas, hubungan masyarakat dan protokol

h. Penyelenggaraan pemberian organisasi dan tatalaksana dalam arti membina dan memelihara seluruh kegiatan kelembagaan dan ketatalaksanaan di lingkungan kantor dan usaha-usaha pengembangannya

i. Penyiapan rancangan peraturan dan/atau keputusan serta pelaksanaan penilaian dan/atau keputusan yang berhubungan bidang tugasnya

j. Penyiapan rancangan Perda dan Keputusan Bupati tentang Ketentraman, ketertiban, Penegakan Hukum, Perlindungan Masyarakat, Operasional dan Pengendalian

k. Pemberian sarana pertimbangan sebagai bahan kebijakan Pimpinan

1. Pelaksanaan tugas lain yang diberikan oleh Kepala Kantor

m. Penyusunan laporan kegiatan Kantor 


\section{Seksi Ketentraman dan Ketertiban}

1. Seksi Ketentraman dan ketertiban mempunyai tugas pokok melaksanakan kegiatan operasional ketentraman dan ketertiban serta menyiapkan bahan penyusunan petunjuk teknis operasional ketentraman dan ketertiban

2. Untuk menyelenggarakan tugas pokok sebagaimana dimaksud pada ayat (1) dalam pasal ini. Seksi Ketentraman dan Ketertiban mempunyai fungsi :

a. Penyusunan kebijaksanaan teknis pembinaan ketentraman dan ketertiban umum

b. Penyusunan program penyuluhan dalam rangka penegakan ketentraman, ketertiban dan pelaksanaan pembinaan trantib serta sosialisasi segala ketentraman perundangan yang memuat ketentuan larangan, peringatan dan ancaman pelanggaran pidana di wilayah dan lingkungan Pemerintah Kabupaten Subang

c. Penyusunan prosedur tetap kegiatan operasional ketentraman dan ketertiban

d. Pelaksanaan evaluasi terhadap pelaksanaan program ketentraman dan ketertiban

e. Pemeliharaan situasi dan kondisi dalam rangka terwujudnya stabilitas politik ekonomi dan sosial budaya di Kabupaten Subang

f. Pemberian saran pertimbangan sebagai bahan kebijakan Pimpinan

g. Pelaksanaan tugas lain yang diberikan oleh Kepala Kantor

h. Penyusunan laporan ketentraman dan ketertiban 
i. Pelaksanaan pembinaan ketenteraman dan ketertiban umum terhadap masyarakat atau Badan Hukum agar mematuhi dan mentaati Peraturan Daerah, Peraturan / Keputusan Bupati

j. Pelaksanaan Penyuluhan / Sosialisasi atau Badan Hukum guna menumbuhkan kepatuhan dan ketaatan terhadap Peraturan Daerah, Peraturan / Keputusan Bupati

4. Seksi Pengendalalian Operasional

1. Seksi Pengendalian Operasional mempunyai tugas pokok melaksanakan pengendalian operasional serta menyiapkan bahan penyusunan petunjuk teknis kegiatan pengendalian operasional

2. Untuk menyelenggarakan tugas pokok sebagaimana dimaksud pada ayat

(1) dalam Pasal ini, Seksi Pengendalian Operasional mempunyai fungsi :

a. Penyusunan program kerja pengendalian operasional dalam rangka penegakan Peraturan Perundang-undangan Daerah

b. Penyusunan rencana operasional (Renop) beserta rencana pengendalian kegiatan

c. Pelaksanaan tugas pengamanan dan pengawalan tamu negara dan pejabat daerah

d. Peningkatan kualitas Kesatuan Polisi Pamong Praja

e. Pemberian saran pertimbangan sebagai bahan kebijakan Pimpinan

f. Pelaksanaan tugas dinas lain yang diberikan oleh Pimpinan

g. Penyusunan laporan kegiatan pengendalian operasional 


\section{Seksi Penegakan}

1. Seksi Penegakan mempunyai tugas pokok membantu Kepala Kantor Satuan Polisi Pamong Praja dalam melaksanakan Kebijakan Penegakan, Pengamanan Perda, Peraturan / Keputusan Bupati.

2. Untuk menyelenggarakan tugas pokok sebagaimana dimaksud pada ayat

(1) dalam Pasal ini, Seksi Penegakan mempunyai fungsi :

a. Pengumpulan dan Pengolahan data dalam rangka penyusunan rencana pelaksanaan Kebijakan Penegakan, Pengamanan Perda dan Peraturan Keputusan Bupati.

b. Pelaksanaan operasi Penegakan Peraturan Daerah dan Peraturan / Keputusan Bupati yang bersifat non yustisial.

c. Pelaksanaan tindakan refresif non yustisial dan yustisial oleh yang berpredikat PPNS terhadap warga atau Badan Hukum yang melakukan Pelanggaran atas Perda dan Peraturan Keputusan Bupati.

d. Pelaksanaan Penyelesaian di Bidang Hukum.

e. Pengkoordinasian Petugas PPNS di Lingkungan Pemerintah Kabupaten Subang.

f. Pelaksanaan Koordinasi dengan Aparat Keamanan, Kejaksaan dan Pengadilan Negeri.

g. Pelaksanaan Evaluasi Pelaksanaan Penegakan Produk Hukum Daerah.

h. Penyusunan Laporan Hasil Pelaksaan Tugas. 
6. Kelompok Jabatan Fungsional

a. Kelompok Jabatan Fungsional mempunyai tugas pokok melaksanakan sebagian kegiatan Kantor secara profesional sesuai dengan kebutuhan

b. Kelompok Jabatan Fungsional sebagaimana dimaksud pada ayat (1) dalam pasal ini, dalam melaksanakan tugas pokoknya bertanggung jawab kepada Kepala Kantor.

\section{BAGAN STRUKTUR ORGANISASI SATUAN POLISI PAMONG PRAJA KABUPATEN SUBANG}

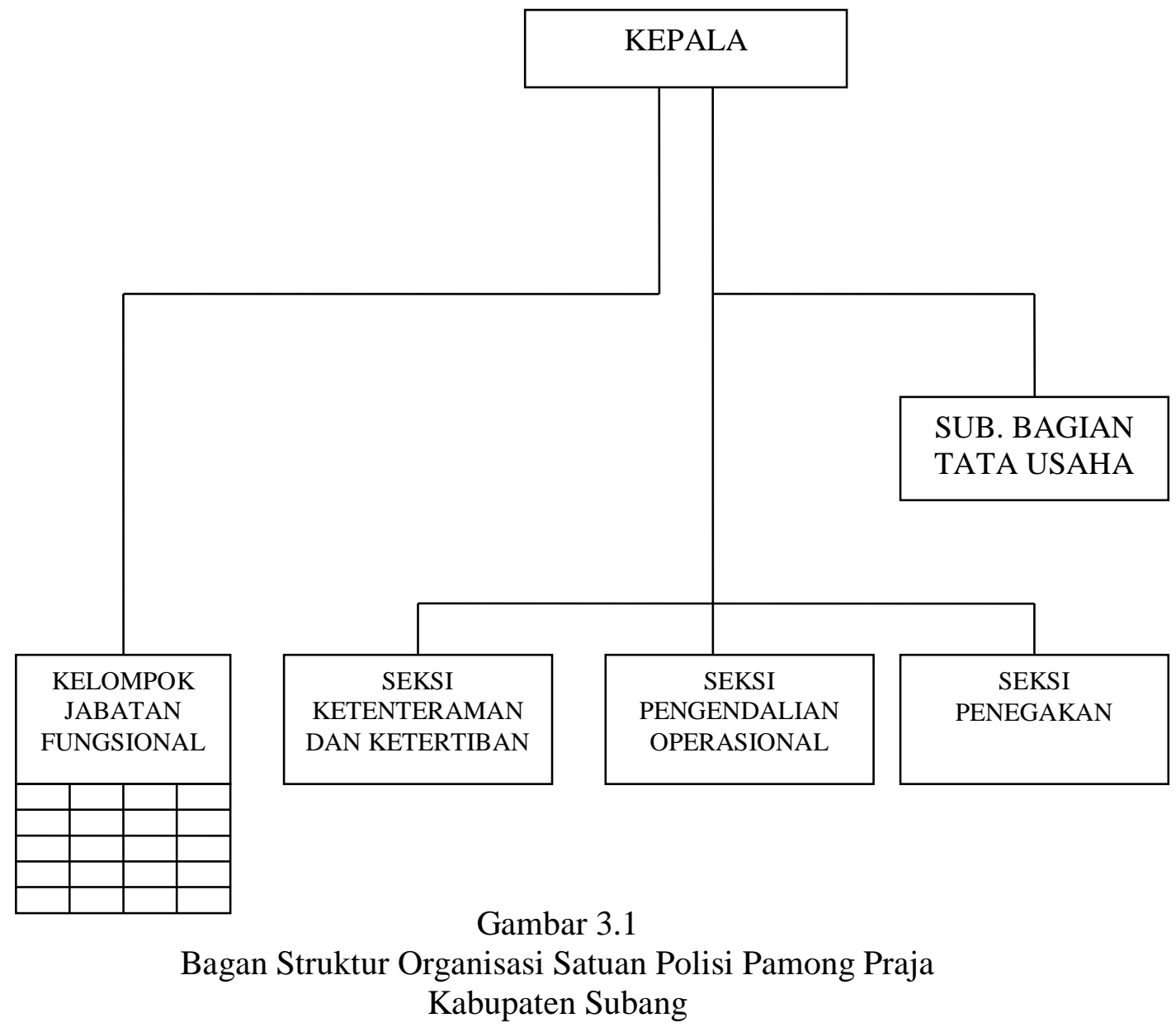




\subsection{Metode Penelitian}

Metode penelitian yang digunakan oleh penulis adalah survei. Penelitian survei pada umumnya dilakukan untuk mengambil suatu generalisasi dari pengamatan. Agar generalisasi yang dilakukan mendapatkan hasil yang akurat, maka diperlukan sampel yang resprensif dari suatu populasi. Adapun tujuan dari metode survei adalah untuk mengumpulkan informasi faktual secara detail, mengindentifikasi masalah dan justifikasi kondisi saat ini serta membuat perbandingan dan evaluasi/kesimpulannya.

Instrumen yang digunakan adalah angket, maksudnya dalam survei ini informasi dikumpulkan dari responden dengan menggunakan angket. Umumnya, pengertian survei dibatasi pada penelitian yang datanya dikumpulkan dari sampel atas populasi untuk mewakili populasi.

Pendekatan penelitian ini adalah deskriritif analisis yang menggambarkan masing-masing variabel yang menguji kedua variabel melalui pendekatan kuantitatif.

\subsubsection{Desain Penelitian}

Desain penelitian menggambarkan hubungan terstruktur variabel-variabel secara komprehensif, yaitu hubungan antara variabel bebas (X) Implementasi Kebijakan dengan variabel terikat (Y) Kinerja pegawai, agar hasil penelitian dapat memberikan jawaban atas hipotesis penelitian.

Desain penelitian secara konseptual yang akan digunakan oleh peneliti dapat digambarkan sebagai berikut : 


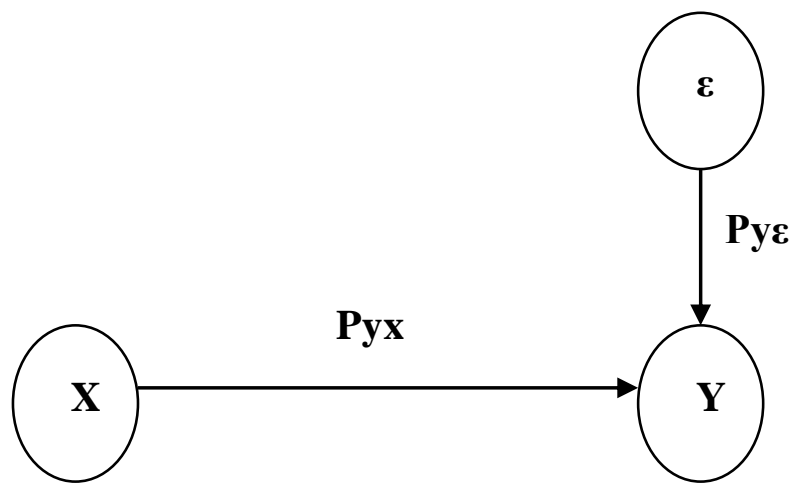

Gambar 3.2

Desain Variabel Penelitian

Keterangan :

$\mathrm{X}=$ Variabel Implementasi

$\mathrm{Y} \quad=$ Variabel Kinerja Pegawai

Pyx $\quad=$ Koefesien $\mathrm{X}$ dan $\mathrm{Y}$

$\varepsilon \quad=$ Variabel yang mempengaruhi di luar variabel yang diteliti

Pye $=$ Koefesien variabel residu / epsilon

\subsubsection{Variabel dan Operasionalisasi Variabel Penelitian}

Penelitian ini meliputi dua variabel, yaitu Implementasi Kebijakan sebagai variabel bebas (X) dan Kinerja Pegawai sebagai variabel terikat (Y).

Operasionalisasi variabel dalam penelitian ini dimaksudkan untuk memudahkan atau mengarahkan di dalam penyususnan alat ukur data yang diperlukan berdasarkan kerangka konseptual penelitian yang telah dikemukan batasan operasionalisasi dari masing-masing variabel penelitian. Secara jelas variabel operasionalisasi penelitian dapat di lihat pada tabel berikut ini : 
Tabel 3.1

Operasionalisasi Variabel Penelitian

\begin{tabular}{|c|c|c|c|}
\hline Variabel & Faktor-Faktor & Indikator & $\begin{array}{c}\text { Item No. } \\
\text { Pertayaan }\end{array}$ \\
\hline (1) & (2) & (3) & (4) \\
\hline \multirow[t]{6}{*}{$\begin{array}{l}\text { Implementasi } \\
\text { Kebijakan } \\
\text { (X) }\end{array}$} & $\begin{array}{l}\text { 1. Standar dan } \\
\text { Sasaran } \\
\text { Kebijakan }\end{array}$ & $\begin{array}{l}\text { a. Kejelasan Kebijakan } \\
\text { b. Keterukuran } \\
\text { keberhasilan kebijakan }\end{array}$ & $\begin{array}{l}1(+), 2(-) \\
3(+), 4(-)\end{array}$ \\
\hline & 2. Sumber Daya & $\begin{array}{l}\text { a. Finansial } \\
\text { b. Kecakapan } \\
\text { implementor }\end{array}$ & $\begin{array}{l}5(+), 6(-) \\
7(+), 8(-)\end{array}$ \\
\hline & 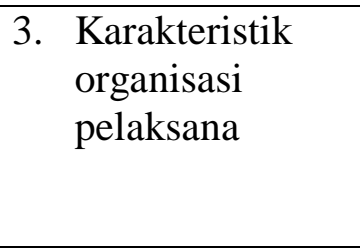 & $\begin{array}{l}\text { a. Daya dukung struktur } \\
\text { organisasi } \\
\text { b. Hubungan dan } \\
\text { komunikasi internal } \\
\text { birokrasi }\end{array}$ & $\begin{array}{l}9(+), 10(-) \\
11(+), 12(-)\end{array}$ \\
\hline & $\begin{array}{l}\text { 4. Komunikasi } \\
\text { antar organisasi } \\
\text { pelaksana dan } \\
\text { kegiatan- } \\
\text { kegiatan } \\
\text { pelaksanaan }\end{array}$ & $\begin{array}{l}\text { a. Koordinasi } \\
\text { b. Kerjasama } \\
\text { c. Standar Operating } \\
\quad \text { Prosedur (SOP) }\end{array}$ & $\begin{array}{l}13(+), 14(-) \\
15(+), 16(-) \\
17(+), 18(-)\end{array}$ \\
\hline & $\begin{array}{l}\text { 5. Sikap para } \\
\text { Pelaksana }\end{array}$ & $\begin{array}{l}\text { a. Demokratis } \\
\text { b. Antusias } \\
\text { c. Responsif }\end{array}$ & $\begin{array}{l}19(+), 20(-) \\
21(+), 22(-) \\
23(+), 24(-)\end{array}$ \\
\hline & $\begin{array}{l}\text { 6. Lingkungan } \\
\text { sosial, ekonomi } \\
\text { dan politik }\end{array}$ & $\begin{array}{l}\text { a. Elite politik } \\
\text { b. Kelompok-kelompok } \\
\text { kepentingan }\end{array}$ & $\begin{array}{l}25(+), 26(-) \\
27(+), 28(-)\end{array}$ \\
\hline Variabel & Dimensi-dimensi & Indikator & $\begin{array}{l}\text { Item No. } \\
\text { Pertayaan }\end{array}$ \\
\hline \multirow[t]{3}{*}{$\begin{array}{l}\text { Kinerja } \\
\text { Pegawai } \\
\text { (Y) }\end{array}$} & 1. Kualitas Kerja & $\begin{array}{l}\text { a. Ketepatan } \\
\text { b. Ketelitian } \\
\text { c. Keterampilan } \\
\text { d. Keberhasilan }\end{array}$ & $\begin{array}{l}29(+), 30(-) \\
31(+), 32(-) \\
33(+), 34(-) \\
35(+), 36(-)\end{array}$ \\
\hline & 2. Kuantitas Kerja & $\begin{array}{l}\text { a. Pekerjaan orientasi } \\
\text { tujuan } \\
\text { b. Tugas khusus }\end{array}$ & $\begin{array}{l}37(+), 38(-) \\
39(+), 40(-)\end{array}$ \\
\hline & 3. Keandalan & $\begin{array}{l}\text { a. Intruksi } \\
\text { b. Kemampuan } \\
\text { c. Inisiatif } \\
\text { d. Kehati-hatian } \\
\text { e. Kerajinan } \\
\end{array}$ & $\begin{array}{l}41(+), 42(-) \\
43(+), 44(-) \\
45(+), 46(-) \\
47(+), 48(-) \\
49(+), 50(-)\end{array}$ \\
\hline
\end{tabular}




\begin{tabular}{|l|l|l|c|}
\hline (1) & \multicolumn{1}{|c|}{$(\mathbf{2})$} & \multicolumn{1}{c|}{$(\mathbf{3})$} & \multicolumn{1}{c|}{$(\mathbf{4})$} \\
\hline & 4. Sikap & a. Sikap pada organisasi & $51(+), 52(-)$ \\
& & b. Sikap pada Orang lain & $53(+), 54(-)$ \\
& & c. Sikap pada pekerjaan & $55(+), 56(-)$ \\
& & d. Sikap pada Kerjasama & $57(+), 58(-)$ \\
\hline
\end{tabular}

\subsubsection{Populasi Penelitian}

Penulis / peneliti mendapatkan data terakhir pada Kantor Satuan Polisi Pamong Praja Kabupaten Subang adalah 93 Orang Pegawai. Dari jumlah anggota populasi (N) 93 Orang pegawai yang dijadikan responden yaitu pegawai-pegawai yang mempunyai jabatan dan pegawai-pegawai yang ada dalam struktur organisasi. Penelitian yang digunakan oleh peneliti yaitu Sensus.

Tabel 3.2.

Populasi Sasaran Responden

\begin{tabular}{|c|l|c|}
\hline NO. & \multicolumn{1}{|c|}{ Jabatan / Struktur Organisasi } & N \\
\hline 1. & Bagian Tata Usaha & 8 \\
\hline 2. & Kasi Penegak Perda & 3 \\
\hline 3. & Kasi Dal Ops & 3 \\
\hline 4. & Kasi Trantib & 3 \\
\hline 5. & Peleton A & 20 \\
\hline 6. & Peleton B & 20 \\
\hline 7. & Peleton C & 23 \\
\hline 8. & Pengamanan Tertutup & 13 \\
\hline \multicolumn{2}{|c}{ Jumlah } & $\mathbf{9 3}$ \\
\hline
\end{tabular}

\subsubsection{Teknik Pengumpulan Data}

Teknik pengumpulan data yang dipergunakan adalah sebagai berikut :

a. Studi Kepustakaan, yaitu mempelajari buku-buku atau bahan-bahan tertulis lain yang ada hubungannya dengan penelitian yang dilakukan. 
b. Penelitian lapangan, terdiri dari :

1) Observasi non partisipasi, yaitu suatu teknik pengumpulan data yang dilakukan melalui pengamatan lapangan obyek penelitian. Kegiatan observasi ini antara lain dengan mencermati berbagai kegiatan yang dilakukan pegawai dalam melaksanakan tugas / pekerjaannya, maupun yang mengaitkan berbagai data yang diperoleh dari wawancara dengan mahasiswa sebagai pelanggan.

2) Wawancara, yaitu Wawancara ini dilakukan peneliti dengan Kepala Satuan Polisi Pamong Praja Kabupaten Subang.

3) Angket, yaitu suatu teknik pengumpulan data dengan penyebaran suatu daftar pertanyaan yang disediakan alternatif jawaban yang telah disusun berdasarkan skala ordinal.

\subsubsection{Teknik Analisis Data}

Sesuai dengan teknik pengumpulan data yang menggunakan instrumen penelitian berbentuk angket, maka jawaban setiap item intrumen menggunakan skala Likert mempunyai gradasi dari sangat positif sampai sangat negatif, yaitu sebagai berikut :

Tabel 3.3.

Alternatif Jawaban Responden

\begin{tabular}{|c|l|c|c|}
\hline No. & \multicolumn{1}{|c|}{ Alternatif Jawaban } & $\begin{array}{c}\text { Skor Item } \\
\text { Positif }\end{array}$ & $\begin{array}{c}\text { Skor Item } \\
\text { Negatif }\end{array}$ \\
\hline 1. & Sangat Setuju (SS) & 5 & 1 \\
\hline 2. & Setuju (S) & 4 & 2 \\
\hline 3. & Netral (N) & 3 & 3 \\
\hline 4. & Tidak Setuju (TS) & 2 & 4 \\
\hline 5. & Sangat Tidak Setuju (STS) & 1 & 5 \\
\hline
\end{tabular}


Data yang terkumpul melalui kuesioner ini adalah data yang berskala ordinal, sedangkan peringkat data untuk dapat digunakan dalam statistika inferensial (analisis jalur), yang digunakan dalam pengujian hipotesis penelitian ini, adalah peringkat data interval. Oleh karena itu, maka data tersebut terlebih dahulu dilakukan konversi dari skala ordinal ke skala interval. Teknik yang digunakan adalah metode interval berurutan (methods of successive interval) (Hays, dalam Harum AI-Rasyid, 1994). Formulasinya adalah sebagai berikut:

$$
\mathrm{SV}=\frac{(\text { density at lower limit })-(\text { density at upper limit })}{\text { (area under upper limit })-(\text { area density under lower limit })}
$$

Proses perhitungan konversi data ordinal ke data interval dilakukan melalui alat bantu untuk mengolah data statistik dengan menggunakan SPSS.

Menganalisis data dari responden yang diperoleh dari angket, digunakan analisis statistik diantaranya merumuskan hipotesis, menyusun instrument penelitian, menentukan sampel, analisis data dan terakhir suatu kesimpulan dari hasil penelitian. Analisis dalam pengolahan data melalui analisis jalur (path analysis) yaitu melihat besarnya pengaruh dari variabel implementasi kebijakan terhadap kinerja pegawai di Kantor Satuan Polisi Pamong Praja Kabupaten Subang. Analisis jalur dalam penelitian ini digambarkan pada diagram penelitian di bawah ini : 


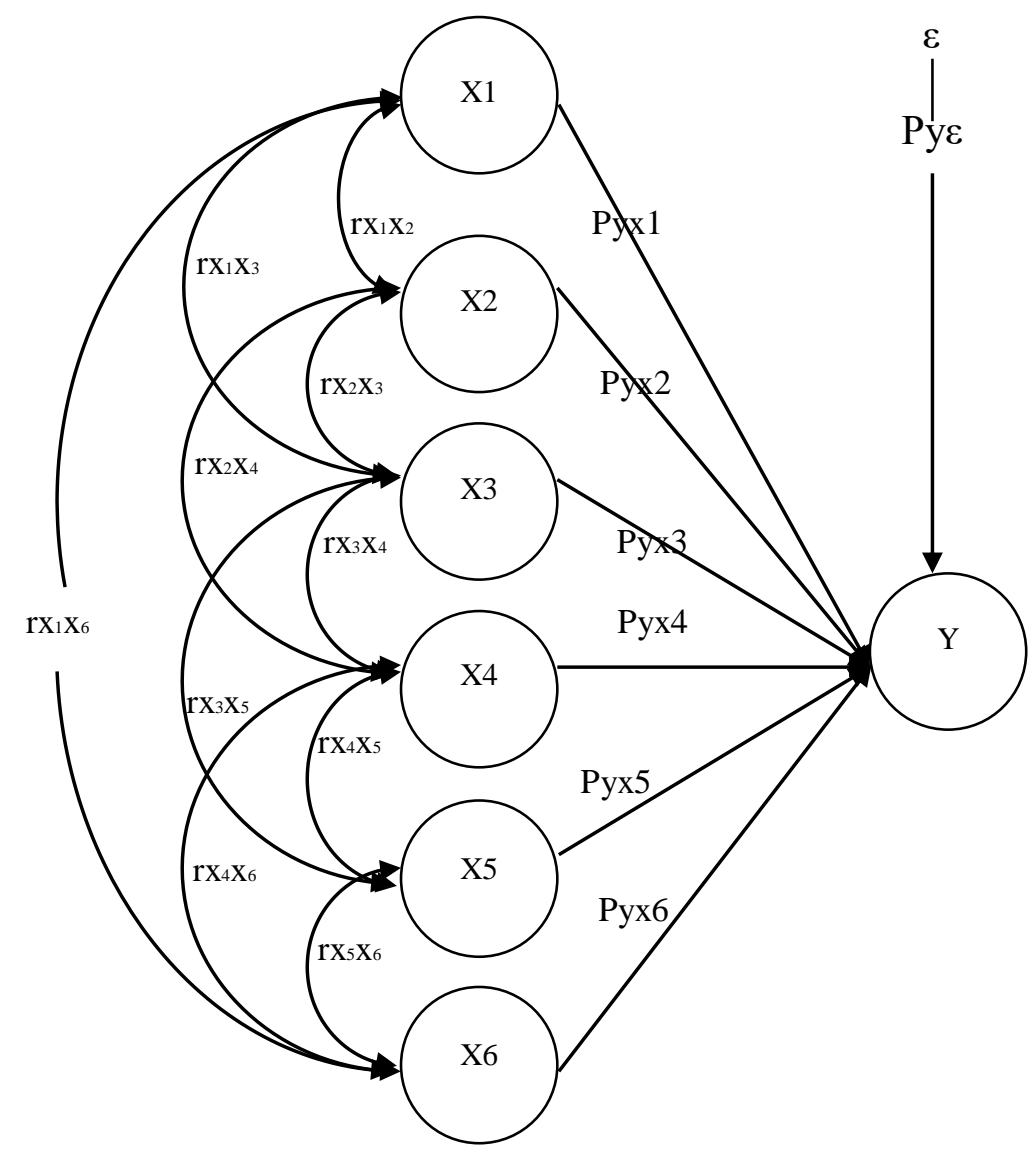

Gambar 3.3

Paradigma Penelitian

Keterangan :

$\mathrm{X} 1=$ Standar dan sasaran kebijakan

$\mathrm{X} 2=$ Sumber daya

X3 = Karakteristik organisasi pelaksana

$\mathrm{X} 4=$ Komunikasi organisasi pelaksana dan kegiatan-kegiatan pelaksanaan

X5 = Sikap para pelaksana

X6 = Lingkungan, sosial, ekonomi dan politik

$\mathrm{Y}=$ Kinerja

Pyx1......Pyx6 = Koefesien jalur dari X1.....X6 ke Y

$P \boldsymbol{\varepsilon}_{\mathrm{x}_{1} \ldots .} \mathbf{P \varepsilon} \mathrm{x}_{6}=$.Koefisien epsilon

Py $\varepsilon=$ Koefesien variabel residu / epsilon 


\section{Uji Validitas}

Suatu alat ukur yang tinggi validitasnya akan memiliki eror pengukuran yang kecil, artinya skor setiap subjek yang diperoleh oleh alat ukur tersebut tidak jauh berbeda dari skor yang sesungguhnya. Dengan demikian secara keseluruhan alat test yang bersangkutan akan menghasilkan varians error yang kecil pula. Ukuran dari validitas ditentukan oleh tingkatan hubungan atau tingkat keeratan (korelasi) antara item-item yang ada dengan jumlah skor dengan menggunakan rumus Produck Moment, sebagai berikut :

$$
r=\frac{\sum X Y-\left(\sum X\right)\left(\sum Y\right) / n}{\sqrt{\left[\sum \mathrm{X}^{2}-\left(\sum \mathrm{X}\right)^{2} / \mathrm{n}\right]\left[\sum \mathrm{Y}^{2}-\left(\sum \mathrm{Y}\right)^{2} / \mathrm{n}\right]}}
$$

\footnotetext{
Keterangan :

$\mathrm{r} \quad=$ Koefesien korelasi Pearson antara item dengan variabel yang bersangkutan.

$\mathrm{X}=$ Skor item dalam variabel

$\mathrm{Y}=$ Skor semua item dalam variabel tersebut

$\mathrm{n}=$ jumlah responden
}

Tujuan dari uji validitas adalah untuk mengetahui valid atau tidaknya instrumen tersebut dengan objek yang diukur. Maksudnya bahwa sebelum dilakukan analisis lebih lanjut maka suatu instrumen (angket) perlu diuji keabsahannya terlebih dahulu sebagai alat ukur.

\section{Uji Reliabilitas}

Pengujian ini bertujuan mengetahui keandalan alat ukur yang digunakan. Keandalan ini menunjukan ketepatan dan homogenitas angket yang digunakan 
sebagai alat ukur. Metode yang digunakan untuk menguji reliabilitas (keandalan) alat ukur pada penelitian ini untuk menghitung koefisien reliabilitas, Alfa Cronbach dalam Sugiyono (2007:365) menggunakan rumus sebagai berikut:

$$
\begin{aligned}
& \text { k } \quad \Sigma \sigma_{b^{2}}
\end{aligned}
$$

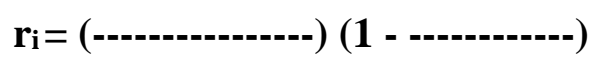

$$
\begin{aligned}
& \mathbf{k}-1 \quad \sigma \mathbf{t}^{2} \\
& \text { Dimana } \quad \mathbf{r}_{\mathbf{i}}=\text { Reliabilitas Instrumen } \\
& \mathrm{k}=\text { Banyak butir pertanyaan } \\
& \sigma \mathrm{t}^{2}=\text { Varians Total } \\
& \Sigma \sigma_{\mathrm{b}}{ }^{2}=\text { Jumlah Varians Butir }
\end{aligned}
$$

Data dari kedua variabel yang diukur menggunakan instrumen pengukuran dangan skala Likert's yang menghasilkan skala pengukuran ordinal, dirubah terlebih dahulu dengan menggunakan Metode Succesive Interval sehingga diperoleh data dengan skala pengukuran interval. Selain itu juga, demi mempermudahkan mengolah data yang sudah didapatkan oleh peneliti dilapangan. Maka untuk mengolah data tersebut dalam proses penghitungan peneliti menggunakan bantuan program SPSS 17.

\subsubsection{LOKASI DAN LAMANYA PENELITIAN}

Penelitian dilaksanakan pada Kantor Satuan Polisi Pamong Praja Kabupaten Subang yang beralamat Jl. Dewi Sartika No. 02 Telp. (0260) 416074 Subang. Dalam melakukan penelitian ini untuk mengumpulkan data-data yang diperlukan, peneliti melakukan penelitian diperkirakan selama 6 (enam) bulan 
terhitung mulai bulan Maret sampai dengan bulan Agustus 2010, penelitian ini dimulai dari tahap persiapan sampai dengan tahap penulisan laporan.

Jadwal penelitian lebih jelasnya dituangkan dalam tabel jadwal penelitian sebagai berikut:

\begin{tabular}{|c|c|c|c|c|c|c|c|c|c|c|c|c|c|c|c|c|c|c|c|c|c|c|c|c|c|}
\hline \multirow{3}{*}{$\begin{array}{l}\mathrm{N} \\
\mathrm{O}\end{array}$} & Tahun & \multicolumn{24}{|c|}{2010} \\
\hline & Bulan & \multicolumn{4}{|c|}{ Mar } & \multicolumn{4}{|c|}{ Apr } & \multicolumn{4}{|c|}{ Mei } & \multicolumn{4}{|c|}{ Juni } & \multicolumn{4}{|c|}{ Juli } & \multicolumn{4}{|c|}{ Agus } \\
\hline & $\begin{array}{l}\text { Minggu } \\
\text { Kegiatan }\end{array}$ & 1 & 2 & 3 & 4 & 1 & 2 & 3 & 4 & 1 & 2 & 3 & 4 & 1 & 2 & 3 & 4 & 1 & 2 & 3 & 4 & 1 & 2 & 3 & 4 \\
\hline 1. & Persiapan UP & & & & & & & & & & & & & & & & & & & & & & & & \\
\hline 2. & Penjajagan & & & & & & & & & & & & & & & & & & & & & & & & \\
\hline 3. & $\begin{array}{l}\text { Penyusunan } \\
\text { UP dan } \\
\text { bimbingan } \\
\text { UP }\end{array}$ & & & & & & & & & & & & & & & & & & & & & & & & \\
\hline 4. & Seminar UP & & & & & & & & & & & & & & & & & & & & & & & & \\
\hline 5. & Perbaikan UP & & & & & & & & & & & & & & & & & & & & & & & & \\
\hline 6. & $\begin{array}{l}\text { Penelitian } \\
\text { Lapangan }\end{array}$ & & & & & & & & & & & & & & & & & & & & & & & & \\
\hline & a.Observasi & & & & & & & & & & & & & & & & & & & & & & & & \\
\hline & b.Wawancara & & & & & & & & & & & & & & & & & & & & & & & & \\
\hline & c. Angket & & & & & & & & & & & & & & & & & & & & & & & & \\
\hline 7. & $\begin{array}{l}\text { Penulisan } \\
\text { dan } \\
\text { Bimbingan } \\
\text { Tesis }\end{array}$ & & & & & & & & & & & & & & & & & & & & & & & & \\
\hline 8. & Sidang Tesis & & & & & & & & & & & & & & & & & & & & & & & & \\
\hline 9. & $\begin{array}{l}\text { Perbaikan } \\
\text { Tesis }\end{array}$ & & & & & & & & & & & & & & & & & & & & & & & & \\
\hline
\end{tabular}

Gambar 3.4

Diagram Jadwal Penelitian 


\section{BAB IV}

\section{HASIL PENELITIAN DAN PEMBAHASAN}

\subsection{Hasil Penelitian}

Hasil penelitian ini merupakan hasil observasi peneliti kepada para Pegawai Satuan Polisi Pamong Praja Kabupaten Subang, maka peneliti/penulis akan menguraikannya sebagai berikut hasil penelitian dan pembahasannya.

\subsubsection{Pengujian Instrumen Penelitian}

Variabel penelitian ini terdiri dari dua variabel, yaitu variabel implementasi kebijakan sebagai variabel bebas yang diberi simbol $\mathrm{X}$ dan kinerja pegawai sebagai variabel tidak bebas yang diberi simbol Y. Penelitian ini dilakukan dengan cara menganalisis variabel implementasi kebijakan yang diperkirakan mempunyai pengaruh besar terhadap kinerja pegawai, rangkaian penelitian yang dilakukan sebagai suatu Studi Implementasi Mengenai Peraturan Daerah Kabupaten Subang No. 13 Tahun 2006 Tentang Ketertiban, Kebersihan dan Keindahan.

Penelitian ini yang dijadikan sebagai unit analisis adalah para pegawai Satuan Polisi Pamong Praja di Kab. Subang, dengan keseluruhan jumlah pegawai sebanyak 93 orang diambil sebagai responden. Selanjutnya kepada responden tersebut diajukan pernyataan-pernyataan dalam angket yang merupakan penjabaran dari indikator-indikator variabel implementasi kebijakan dan variabel kinerja pegawai. 
Indikator-indikator dalam setiap variabel penelitian dituangkan ke dalam pernyataan tertutup, dimana setiap pernyataan angket memiliki lima alternatif jawaban yang dapat dipilih oleh responden. Alternatif tersebut diberi skor dari 5 sampai 1 untuk pernyataan yang positif dan skor 1 sampai 5 untuk pernyataan yang negatif.

Uji validitas dan reliabilitas sangat penting dalam pengujian instrumen sebagai alat dalam penelitian ini, uji validitas menilai sejauh mana instrumen yang digunakan telah sahih untuk mengukur variabel, dan uji reliabilitas digunakan untuk menilai tingkat kehandalan instrumen penelitian.

\subsubsection{Uji Validitas}

Angket penelitian disusun dalam dua kelompok sesuai dengan banyaknya variabel penelitian. Jumlah item keseluruhan adalah lima puluh delapan item pernyataan. Angket yang digunakan dalam mengukur variabel, terdiri dari variabel implementasi kebijakan (X) yang dibagi menjadi enam faktor yaitu Standar dan Sasaran Kebijakan (X1), Sumber daya (X2), Karakteristik organisasi pelaksana (X3), Komunikasi antar organisasi pelaksana dan kegiatan-kegiatan pelaksanaan (X4), Sikap para pelaksana (X5), Lingkungan sosial ekonomi dan politik (X6). Sedangkan sebagai variabel terikatnya yaitu kinerja pegawai (Y) yang dilihat dari empat faktor, yaitu kualitas kerja (Y1), kuantitas kerja (Y2), keandalan (Y3) dan sikap (Y4). Semua pernyataan angket diukur dalam skala ordinal dan disusun dalam bentuk skala Likert. 
Pengujian instrumen penelitian sangat penting dilakukan sebelum penelitian dilaksanakan, karena pengujian bertujuan untuk mengetahui apakah instrumen telah memenuhi persyaratan, baik ditinjau dari segi validitasnya maupun dari segi keterandalannya. Sebuah instrumen penelitian dapat dikatakan valid jika instrumen penelitian tersebut dapat digunakan untuk mengukur apa yang seharusnya diukur.

Sebuah instrumen dapat dikatakan sahih apabila dapat mengukur apa yang diukur. Instrumen dikatakan valid apabila instrumen penelitian mampu mengukur variabel implementasi kebijakan dan kinerja pegawai di kantor satuan polisi pamong praja kab.subang. Tinggi rendahnya validitas instrumen menunjukkan sejauh mana data yang terkumpul tidak menyimpang dari gambaran tentang variabel yang dimaksud. Adapun alat pengujian yang dipakai adalah rumus korelasi Product Moment Pearson. sebagai berikut :

1. Penentuan nilai korelasi (r)

Untuk menentukan nilai korelasi, digunakan rumus sebagai berikut :

$\mathrm{r}_{\mathrm{XY}}=\frac{\mathrm{n} \cdot \sum \mathrm{XY}-\left(\sum \mathrm{X}\right) \cdot\left(\sum \mathrm{Y}\right)}{\sqrt{\left.\left\{\mathrm{n} \sum \mathrm{X}^{2}-\left(\sum \mathrm{X}\right)^{2}\right\} \cdot \mathrm{n} \sum \mathrm{Y}^{2}-\left(\sum \mathrm{Y}\right)^{2}\right\}}}$

2. Kaidah Keputusan

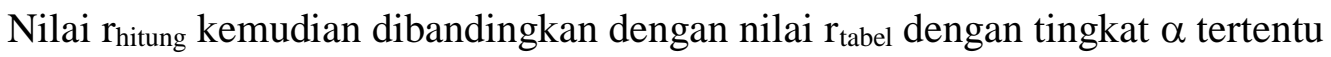
dan derajat bebas sebesar n-2. Kaidah keputusan sebagai berikut :

a. Jika $r_{\text {hitung }}>r_{\text {tabel }}$ maka alat ukur yang digunakan valid

b. Jika $r_{\text {hitung }} \leq r_{\text {tabel }}$ maka alat ukur yang digunakan tidak valid 
Untuk menguji validitas setiap item maka skor-skor yang ada pada item yang dimaksud dikorelasikan dengan skor total. Skor item dipandang sebagai nilai $\mathrm{X}$ dan skor total dipandang sebagal $\mathrm{Y}$. Dengan diperolehnya indeks validitas setiap item dapat diketahui dengan pasti item-item manakah yang tidak memenuhi syarat ditinjau dan validitasnya. Berdasarkan informasi tersebut peneliti dapat mengganti ataupun merevisi item-item dimaksud. Bagi peneliti yang menginginkan, pengujian terhadap item dapat dilakukan dengan mengkorelasikan item dengan skor total pada faktor.

Suatu item dikatakan valid apabila nilai $\mathrm{r}$ atau nilai korelasi antara skor item dengan totalnya menunjukkan koefisien yang signifikan, dikatakan signifikan apabila nilai $r_{\text {tabel }}$ dari item lebih kecil dari nilai $r_{\text {hitung. Nilai }} r_{\text {tabel }}$ mengacu pada tabel $\mathrm{r}$ untuk korelasi product moment dan ditentukan besarnta $\alpha=$ 0.05 dan $n=93$. Berdasarkan perhitungan tersebut diperoleh nilai $r_{\text {tabel }}=0.204$, apabila terdapat pernyataan item yang tidak valid maka data yang didapat tidak bisa digunakan untuk analisis selanjutnya.

Hasil uji validitas terhadap variabel Implementasi kebijakan (X) adalah sebagai berikut:

Tabel 4.1

Hasil Uji Validitas Variabel Implementasi Kebijakan (X)

\begin{tabular}{|c|c|c|c|}
\hline Item & $\mathbf{r}$ & r tabel & Keputusan \\
\hline 1 & 0.228 & 0.204 & Valid \\
\hline 2 & 0.259 & 0.204 & Valid \\
\hline 3 & 0.282 & 0.204 & Valid \\
\hline
\end{tabular}




\begin{tabular}{|c|c|c|c|}
\hline 4 & 0.230 & 0.204 & Valid \\
\hline 5 & 0.232 & 0.204 & Valid \\
\hline 6 & 0.220 & 0.204 & Valid \\
\hline 7 & 0.356 & 0.204 & Valid \\
\hline 8 & 0.231 & 0.204 & Valid \\
\hline 9 & 0.292 & 0.204 & Valid \\
\hline 10 & 0.237 & 0.204 & Valid \\
\hline 11 & 0.208 & 0.204 & Valid \\
\hline 12 & 0.256 & 0.204 & Valid \\
\hline 13 & 0.464 & 0.204 & Valid \\
\hline 14 & 0.340 & 0.204 & Valid \\
\hline 15 & 0.399 & 0.204 & Valid \\
\hline 16 & 0.423 & 0.204 & Valid \\
\hline 17 & 0.441 & 0.204 & Valid \\
\hline 18 & 0.418 & 0.204 & Valid \\
\hline 19 & 0.349 & 0.204 & Valid \\
\hline 20 & 0.320 & 0.204 & Valid \\
\hline 21 & 0.312 & 0.204 & Valid \\
\hline 22 & 0.451 & 0.204 & Valid \\
\hline 23 & 0.289 & 0.204 & Valid \\
\hline 24 & 0.224 & 0.204 & Valid \\
\hline 25 & 0.238 & 0.204 & Valid \\
\hline 26 & 0.210 & 0.204 & Valid \\
\hline 27 & 0.426 & 0.204 & Valid \\
\hline 28 & 0.408 & 0.204 & Valid \\
\hline
\end{tabular}

\section{Sumber : Hasil Pengolahan Data, 2010}

Berdasarkan tabel 4.1 Hasil Uji Validitas Variabel Implementasi Kebijakan (X) diperoleh gambaran bahwa uji instrumen untuk Variabel 
Implementasi kebijakan menunjukkan bahwa semua pernyataan valid, sehingga semua data bisa dilanjutkan ke analisis berikutnya.

Uji validitas untuk variabel Kinerja Pegawai (Y) hasil perhitungannya dapat dijelaskan pada tabel 4.2 sebagai berikut:

Tabel 4.2

Hasil Uji Validitas Variabel Y (Kinerja Pegawai)

\begin{tabular}{|c|c|c|c|}
\hline Item & $\mathbf{r}$ & r tabel & Keputusan \\
\hline 29 & 0.307 & 0.204 & Valid \\
\hline 30 & 0.332 & 0.204 & Valid \\
\hline 31 & 0.214 & 0.204 & Valid \\
\hline 32 & 0.233 & 0.204 & Valid \\
\hline 33 & 0.547 & 0.204 & Valid \\
\hline 34 & 0.451 & 0.204 & Valid \\
\hline 35 & 0.461 & 0.204 & Valid \\
\hline 36 & 0.405 & 0.204 & Valid \\
\hline 37 & 0.205 & 0.204 & Valid \\
\hline 38 & 0.225 & 0.204 & Valid \\
\hline 39 & 0.327 & 0.204 & Valid \\
\hline 40 & 0.428 & 0.204 & Valid \\
\hline 41 & 0.329 & 0.204 & Valid \\
\hline 42 & 0.278 & 0.204 & Valid \\
\hline 43 & 0.333 & 0.204 & Valid \\
\hline 44 & 0.251 & 0.204 & Valid \\
\hline 45 & 0.287 & 0.204 & Valid \\
\hline 46 & 0.231 & 0.204 & Valid \\
\hline 47 & 0.234 & 0.204 & Valid \\
\hline 48 & 0.267 & 0.204 & Valid \\
\hline
\end{tabular}




\begin{tabular}{|c|c|c|c|}
\hline 49 & 0.211 & 0.204 & Valid \\
\hline 50 & 0.314 & 0.204 & Valid \\
\hline 51 & 0.230 & 0.204 & Valid \\
\hline 52 & 0.310 & 0.204 & Valid \\
\hline 53 & 0.255 & 0.204 & Valid \\
\hline 54 & 0.292 & 0.204 & Valid \\
\hline 55 & 0.419 & 0.204 & Valid \\
\hline 56 & 0.326 & 0.204 & Valid \\
\hline 57 & 0.233 & 0.204 & Valid \\
\hline 58 & 0.229 & 0.204 & 2010 \\
\hline
\end{tabular}

Sumber : Hasil Pengolahan Data 2010

Berdasarkan tabel 4.2 Hasil Uji Validitas Variabel Kinerja Pegawai (Y) diperoleh gambaran bahwa yang terdiri dari 30 item pernyataan semuanya valid, sehingga semua data bisa dilanjutkan ke analisis berikutnya.

\subsubsection{Uji Reliabilitas}

Hasil penelitian tergantung pada kualitas data yang dianalisis dan instrumen yang digunakan untuk mengumpulkan data penelitian instrumen pada penelitian ini adalah kuesioner, sehingga data yang diperoleh dari responden akan diuji kualitas datanya dengan menggunakan uji validitas dan uji reliabilitas.

Uji reliabilitas bertujuan untuk menunjukan sejauh mana suatu hasil pengukuran relatif konsisten apabila pengukuran diulangi dua kali atau lebih. Jadi dengan kata lain bahwa reliabilitas adalah indeks yang menunjukan sejauh mana suatu alat pengukur dapat dipercaya atau dapat diandalkan, bila alat pengukur tersebut digunakan dua kali atau lebih untuk mengukur gejala yang sama, dan hasil pengukuran yang diperoleh relatif konsisten. 
Setiap instrumen seharusnya memiliki kemampuan untuk memberikan hasil pengukuran yang konsisten, sehingga hasil pengukuran dapat dipercaya hanya apabila dalam beberapa kali pengukuran terhadap kelompok subyek yang sama diperoleh hasil yang relatif sama, selama prinsip yang diukur dalam diri subyek memang belum berubah. Untuk menghitung koefisien reliabilitas, Alfa Cronbach dalam Sugiyono (2007:365) menggunakan rumus sebagai berikut:

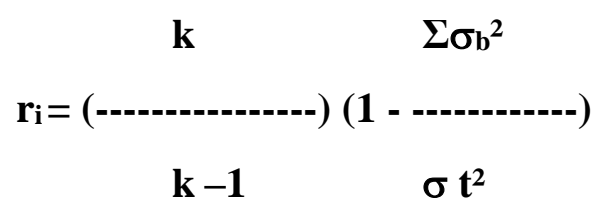

$$
\begin{array}{lll}
\operatorname{Dimana} & \mathbf{r}_{\mathbf{i}} & =\text { Reliabilitas Instrumen } \\
\mathbf{k} & =\text { Banyak butir pertanyaan } \\
\boldsymbol{\sigma}^{2} & =\text { Varians Total } \\
\boldsymbol{\Sigma} \boldsymbol{\sigma}_{\mathbf{b}}{ }^{2} & =\text { Jumlah Varians Butir }
\end{array}
$$

Dengan ketentuan, jika realibilitas kurang dari 0,6 dianggap kurang baik, apabila sekitar angka 0,7 dikategorikan "dapat diterima" dan untuk nilai diatas 0,8 digolongkan realibilitas yang baik.

Berdasarkan hasil perhitungan rumus Alfa Cronbach dengan menggunakan SPPS 17, maka diperoleh keputusan koefisien reliabilitas dari variabel peneltian sebagai berikut:

Tabel 4.3

\section{Hasil Uji Reliabilitas Instrumen Penelitian}

\begin{tabular}{|r|r|}
\multicolumn{2}{|c|}{ Reliability Statistics } \\
$\begin{array}{r}\text { Cronbach's } \\
\text { Alpha }\end{array}$ & N of Items \\
\hline .871 & 58 \\
\hline
\end{tabular}


Tabel 4.3. hasil uji realibilitas instrumen penelitian, menunjukkan bahwa variabel penelitian mempunyai nilai reliabilitas sebesar 0,871 yang berada diatas 0,8 maka dikategorikan realibilitas yang baik. Keputusan hasil uji reliabilitas ini menunjukkan bahwa seluruh instrumen yang digunakan untuk mengukur seluruh item dari variabel implementasi kebijakan dan kinerja pegawai, sebagaimana telah dioperasionalisasikan pada operasionalisasi variabel dapat diterima keterandalan atau kekonsistenannya.

\subsection{Analisis Deskriptif Hasil Penelitian}

\subsubsection{Variabel Implementasi kebijakan}

Analisis deskriptif terhadap variabel Imaplementasi Kebijakan, terdiri dari enam faktor, yaitu Standar dan Sasaran Kebijakan (X1), Sumber daya (X2), Karakteristik organisasi pelaksana (X3), Komunikasi antar organisasi pelaksana dan kegiatan-kegiatan pelaksanaan (X4), Sikap para pelaksana (X5), Lingkungan sosial ekonomi dan politik (X6). Setiap prinsip diwakili oleh beberapa indikator yang dibagi lagi menjadi beberapa item pernyataan. Untuk mengetahui kondisi variabel implementasi kebijakan, maka dilakukan pengukuran dengan menggunakan kuesioner yang terdiri dari 28 pertanyaan, masing-masing disertai lima kemungkinan jawaban yang harus dipilih dan dianggap sesuai menurut responden.

\subsubsection{Faktor Standar dan Sasaran Kebijakan}

Faktor Standar dan Sasaran Kebijakan merupakan faktor pertama dari implementasi kebijakan, faktor Standar dan Sasaran Kebijakan meliputi dua 
indikator yaitu kejelasan kebijakan dan keterukuran kebijakan, dan empat item pernyataan untuk sembilan puluh tiga responden. Adapun hasil jawaban responden yang berkaitan dengan pernyataan yang diajukan dapat dilihat pada tabel 4.4 total skor faktor standar dan sasaran kebijakan sebagai berikut:

Tabel 4.4

Total Skor faktor Standar dan Sasaran Kebijakan

\begin{tabular}{|c|c|c|c|c|c|c|c|c|c|c|c|c|c|c|c|c|c|c|}
\hline \multirow{2}{*}{ No } & \multirow{2}{*}{ Pernyataan } & \multirow{2}{*}{ Kode } & \multicolumn{5}{|c|}{$\mathrm{Fi}$} & \multirow{2}{*}{\multicolumn{5}{|c|}{$\mathrm{Xi}$}} & \multirow{2}{*}{\multicolumn{5}{|c|}{ FixXi }} & \multirow{2}{*}{ Fi.Xi } \\
\hline & & & SS & $\mathrm{S}$ & $\mathrm{N}$ & TS & STS & & & & & & & & & & & \\
\hline 1 & $\begin{array}{l}\text { Satuan Polisi Pamong } \\
\text { Praja mengetahui, } \\
\text { mengerti, dan memahami } \\
\text { mengenai kejelasan } \\
\text { kebijakan Peraturan } \\
\text { Daerah Kabupaten } \\
\text { Subang No. } 13 \text { Tahun } \\
\text { 2006 Tentang Ketertiban, } \\
\text { Kebersihan dan } \\
\text { Keindahan } \\
\end{array}$ & 1 & 49 & 41 & 3 & 0 & 0 & 5 & 4 & 3 & 2 & 1 & 245 & 164 & 9 & 0 & 0 & 418 \\
\hline 2 & $\begin{array}{l}\text { Satuan Polisi Pamong } \\
\text { Praja kurang mengetahui, } \\
\text { mengerti dan memahami } \\
\text { mengenai kejelasan } \\
\text { kebijakan Peraturan } \\
\text { Daerah Kabupaten } \\
\text { Subang No. 13 Tahun } \\
\text { 2006 Tentang Ketertiban, } \\
\text { Kebersihan dan } \\
\text { Keindahan }\end{array}$ & 2 & 27 & 53 & 4 & 7 & 2 & 1 & 2 & 3 & 4 & 5 & 27 & 106 & 12 & 28 & 10 & 183 \\
\hline 3 & $\begin{array}{l}\text { Satuan Polisi Pamong } \\
\text { Praja selalu } \\
\text { memperhatikan } \\
\text { Keterukuran keberhasilan } \\
\text { kebijakan }\end{array}$ & 3 & 21 & 47 & 14 & 10 & 1 & 5 & 4 & 3 & 2 & 1 & 105 & 188 & 42 & 20 & 1 & 356 \\
\hline 4 & $\begin{array}{l}\text { Satuan Polisi Pamong } \\
\text { Praja tidak selalu } \\
\text { memperhatikan } \\
\text { Keterukuran keberhasilan } \\
\text { kebijakan yang penting } \\
\text { kebijakan dapat } \\
\text { dilaksanakan } \\
\end{array}$ & 4 & 9 & 57 & 8 & 6 & 13 & 1 & 2 & 3 & 4 & 5 & 9 & 114 & 24 & 24 & 65 & 236 \\
\hline & & & & & & & & & & & & & & & umla & & & 1193 \\
\hline
\end{tabular}

Sumber: Data Hasil Penelitian,2010 
Tabel 4.4 Total Skor Faktor Standar dan Sasaran Kebijakan, menunjukkan perkalian antara jumlah jawaban responden untuk masing-masing item pernyataan yang memiliki alternatif jawaban Sangat Setuju (SS), Setuju (S), Netral (N), Tidak Setuju (TS), dan Sangat Tidak Setuju (STS) dengan nilai alternatif jawaban mengacu pada skor jawaban untuk item pernyataan yang positif dan negatif. Pernyataan pada prinsip ini menggunakan alternatif jawaban yang positif dan negatif. Pada kolom akhir diperoleh jumlah perkalian antara jumlah responden yang menjawab masing-masing alternatif jawaban dengan skor item pernyataan, dan penjumlahannya menghasilkan total skor, kecenderungan jawaban untuk faktor Standar dan Sasaran Kebijakan, yaitu sebesar $\Sigma \mathbf{f i} . \mathbf{X i}=1193$.

Perhitungan Persentase jawaban responden dapat dilihat pada tabel 4.5. Disribusi Frekuensi faktor standar dan sasaran kebijakan, sebagai berikut :

Tabel 4.5

Distribusi Frekuensi Faktor Standar dan Sasaran Kebijakan

\begin{tabular}{|c|c|c|c|c|c|c|c|c|c|c|c|c|}
\hline \multirow[b]{2}{*}{ No. } & \multirow[b]{2}{*}{ Pernyataan } & \multirow[b]{2}{*}{ Kode } & \multicolumn{5}{|c|}{ Alternatif Jawaban } & \multirow{2}{*}{\multicolumn{5}{|c|}{ Presentase (\%) }} \\
\hline & & & SS & $\mathrm{S}$ & $\mathrm{N}$ & TS & ST & & & & & \\
\hline 1. & $\begin{array}{l}\text { Satuan Polisi Pamong } \\
\text { Praja mengetahui, } \\
\text { mengerti, dan memahami } \\
\text { mengenai kejelasan } \\
\text { kebijakan Peraturan } \\
\text { Daerah Kabupaten } \\
\text { Subang No. 13 Tahun } \\
\text { 2006 Tentang Ketertiban, } \\
\text { Kebersihan dan } \\
\text { Keindahan }\end{array}$ & 1 & 49 & 41 & 3 & 0 & 0 & 52,7 & 44,1 & 3,2 & 0,0 & 0,0 \\
\hline 2. & $\begin{array}{l}\text { Satuan Polisi Pamong } \\
\text { Praja kurang mengetahui, } \\
\text { mengerti dan memahami } \\
\text { mengenai kejelasan } \\
\text { kebijakan Peraturan } \\
\text { Daerah Kabupaten } \\
\text { Subang No. } 13 \text { Tahun } \\
\text { 2006 Tentang Ketertiban, }\end{array}$ & 2 & 27 & 53 & 4 & 7 & 2 & 29,0 & 57,0 & 4,3 & 7,5 & 2,2 \\
\hline
\end{tabular}




\begin{tabular}{|c|c|c|c|c|c|c|c|c|c|c|c|c|}
\hline & $\begin{array}{l}\text { Kebersihan dan } \\
\text { Keindahan }\end{array}$ & & & & & & & & & & & \\
\hline 3. & $\begin{array}{l}\text { Satuan Polisi Pamong } \\
\text { Praja selalu } \\
\text { memperhatikan } \\
\text { Keterukuran keberhasilan } \\
\text { kebijakan }\end{array}$ & 3 & 21 & 47 & 14 & 10 & 1 & 22,6 & 50,5 & 15,1 & 10,8 & 1,1 \\
\hline 4. & $\begin{array}{l}\text { Satuan Polisi Pamong } \\
\text { Praja tidak selalu } \\
\text { memperhatikan } \\
\text { Keterukuran keberhasilan } \\
\text { kebijakan yang penting } \\
\text { kebijakan dapat } \\
\text { dilaksanakan }\end{array}$ & 4 & 9 & 57 & 8 & 6 & 13 & 9.7 & 61,3 & 8,6 & 6,5 & 14,0 \\
\hline
\end{tabular}

\section{Sumber: Data Hasil Penelitian,2010}

Berdasarkan tabel 4.5 distribusi frekuensi faktor standar dan sasaran kebijakan, menggambarkan bahwa faktor standar dan sasaran kebijakan telah dilaksanakan sesuai tujuan dan sasaran kebijakan. Namun masih ada kendala didalam memahami dan mengerti tentang isi kebijakan tersebut. Hal ini dapat dilihat dari hasil pengumpulan data yang mengacu pada kuesioner, diperoleh skor rentang nilai data untuk faktor standar dan sasaran kebijakan yang diwakili oleh empat item pernyataan untuk sembilan puluh tiga responden. Rentang nilai diperoleh dari perkalian antara jumlah responden dengan empat item pernyataan, dan selanjutnya dikalikan dengan skor alternatif jawaban, sehingga diperoleh skor rentang nilai jawaban maksimum $\left(\mathrm{R}_{\text {maks }}=1860\right)$, dan nilai jawaban minimum $\left(\mathrm{R}_{\min }=372\right)$ sebagai berikut :

93 responden x 4 item x $5=1860$

93 responden x 4 item x $4=1488$

93 responden $\mathrm{x} 4$ item $\mathrm{x} 3=1116$

93 responden $\mathrm{x} 4$ item $\mathrm{x} 2=744$

93 responden $\mathrm{x} 4$ item $\mathrm{x} 1=372$ 
Hasil perhitungan tersebut memberikan gambaran bahwa faktor standar dan sasaran kebijakan mempunyai Rentang nilai pada hasil penelitian ini yang berdasarkan skor minimum dan skor maksimum jawaban responden yang telah dijelaskan di atas, dan perhitungan pada tabel yang menghasilkan total nilai skor $\Sigma$ fi. $\mathbf{X i}=1193$ digambarkan pada kontinum sebagai berikut:

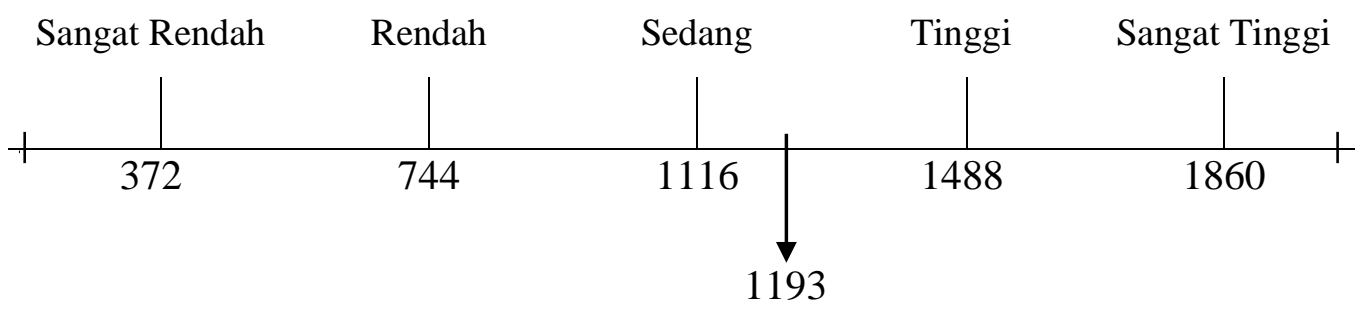

Gambar 4.1

Kontinum Faktor Standar dan Sasaran Kebijakan

Mengacu pada gambar 4.1 kontinum Faktor Standar dan Sasaran Kebijakan bahwa hasil perhitungan di atas yang tertera pada tabel 4.4 total skor Faktor Standar dan Sasaran Kebijakan menunjukan, dengan hasil skor jawaban responden $\Sigma$ fi. $\mathbf{X i}=1193$, dimana hasil tersebut berada pada tahapan antara kontinum sedang menuju ke tinggi. Sehingga dapat dikatakan bahwa faktor standar dan sasaran kebijakan dalam implementasi kebijakan ini sudah berjalan dengan efektif dan pada umumnya responden menganggap sangat penting faktor standar dan sasaran kebijakan ini.

\subsubsection{Faktor Sumber Daya}

Faktor Sumber Daya meliputi dua indikator yaitu Finansial dan Kecakapan Implementor, dan empat item pernyataan untuk sembilan puluh tiga responden. 
Adapun hasil jawaban responden yang berkaitan dengan pernyataan yang diajukan dapat dilihat pada tabel 4.6 total skor faktor sumber daya sebagai berikut:

Tabel 4.6

Total Skor faktor Sumber Daya

\begin{tabular}{|c|c|c|c|c|c|c|c|c|c|c|c|c|c|c|c|c|c|c|}
\hline \multirow{2}{*}{ No } & \multirow{2}{*}{ Pernyataan } & \multirow{2}{*}{ Kode } & \multicolumn{5}{|c|}{$\mathrm{Fi}$} & \multirow{2}{*}{\multicolumn{5}{|c|}{$\mathrm{Xi}$}} & \multirow{2}{*}{\multicolumn{5}{|c|}{ FixXi }} & \multirow{2}{*}{ Fi.Xi } \\
\hline & & & SS & $S$ & $\mathrm{~N}$ & TS & STS & & & & & & & & & & & \\
\hline 1 & $\begin{array}{l}\text { Satuan Polisi Pamong } \\
\text { Praja mempunyai } \\
\text { dukungan finansial yang } \\
\text { memadai untuk menjamin } \\
\text { keberlangsungan } \\
\text { kebijakan }\end{array}$ & 5 & 20 & 55 & 12 & 6 & & 5 & 4 & 3 & 2 & 1 & 100 & 220 & 36 & 12 & 0 & 368 \\
\hline 2 & $\begin{array}{l}\text { Satuan Polisi Pamong } \\
\text { Praja kurang mempunyai } \\
\text { dukungan finansial yang } \\
\text { memadai untuk menjamin } \\
\text { keberlangsungan } \\
\text { kebijakan }\end{array}$ & 6 & 15 & 43 & 20 & 10 & 5 & 1 & 2 & 3 & 4 & 5 & 15 & 86 & 60 & 40 & 25 & 226 \\
\hline 3 & $\begin{array}{l}\text { Satuan Polisi Pamong } \\
\text { Praja mempunyai } \\
\text { Kecapan implementor } \\
\text { dalam pelaksanaan } \\
\text { kebijakan }\end{array}$ & 7 & 25 & 55 & 7 & 6 & & 5 & 4 & 3 & 2 & 1 & 125 & 220 & 21 & 12 & 0 & 378 \\
\hline 4 & $\begin{array}{l}\text { Satuan Polisi Pamong } \\
\text { Praja tidak mempunyai } \\
\text { Kecapan implementor } \\
\text { dalam pelaksanaan } \\
\text { kebijakan }\end{array}$ & 8 & 12 & 53 & 11 & 13 & 4 & 1 & 2 & 3 & 4 & 5 & 12 & 106 & 33 & 52 & 20 & 223 \\
\hline & & & & & & & & & & & & & & & $\mathrm{Im}$ & & & 1195 \\
\hline
\end{tabular}

\section{Sumber: Data Hasil Penelitian,2010}

Tabel 4.6 Total Skor Faktor Sumber Daya, menunjukkan perkalian antara jumlah jawaban responden untuk masing-masing item pernyataan yang memiliki alternatif jawaban Sangat Setuju (SS), Setuju (S), Netral (N), Tidak Setuju (TS), dan Sangat Tidak Setuju (STS) dengan nilai alternatif jawaban mengacu pada skor jawaban untuk item pernyataan yang positif dan negatif. Pernyataan pada prinsip ini menggunakan alternatif jawaban yang positif dan negatif. Pada kolom akhir diperoleh jumlah perkalian antara jumlah responden yang menjawab masing- 
masing alternatif jawaban dengan skor item pernyataan, dan penjumlahannya menghasilkan total skor jawaban untuk faktor Sumber Daya, yaitu sebesar $\Sigma$ fi. $\mathbf{X i}=1195$.

Perhitungan Persentase jawaban responden dapat dilihat pada tabel 4.7 Disribusi Frekuensi faktor Sumber Daya, sebagai berikut :

Tabel 4.7

Distribusi Frekuensi Faktor Sumber Daya

\begin{tabular}{|c|c|c|c|c|c|c|c|c|c|c|c|c|}
\hline \multirow{2}{*}{ No. } & \multirow{2}{*}{ Pernyataan } & \multirow{2}{*}{ Kode } & \multicolumn{5}{|c|}{ Alternatif Jawaban } & \multirow{2}{*}{\multicolumn{5}{|c|}{ Presentase (\%) }} \\
\hline & & & SS & $\mathrm{S}$ & $\mathrm{N}$ & TS & STS & & & & & \\
\hline 1. & $\begin{array}{l}\text { Satuan Polisi Pamong } \\
\text { Praja mempunyai } \\
\text { dukungan finansial yang } \\
\text { memadai untuk menjamin } \\
\text { keberlangsungan } \\
\text { kebijakan }\end{array}$ & 5 & 20 & 55 & 12 & 6 & 0 & 21.5 & 59.1 & 12.9 & 6.5 & 0.0 \\
\hline 2. & $\begin{array}{l}\text { Satuan Polisi Pamong } \\
\text { Praja kurang mempunyai } \\
\text { dukungan finansial yang } \\
\text { memadai untuk menjamin } \\
\text { keberlangsungan } \\
\text { kebijakan }\end{array}$ & 6 & 15 & 43 & 20 & 10 & 5 & 16.1 & 46.2 & 21.5 & 10.8 & 5.4 \\
\hline 3. & $\begin{array}{l}\text { Satuan Polisi Pamong } \\
\text { Praja mempunyai } \\
\text { Kecapan implementor } \\
\text { dalam pelaksanaan } \\
\text { kebijakan }\end{array}$ & 7 & 25 & 55 & 7 & 6 & 0 & 26.9 & 59.1 & 7.5 & 6.5 & 0.0 \\
\hline 4. & $\begin{array}{l}\text { Satuan Polisi Pamong } \\
\text { Praja tidak mempunyai } \\
\text { Kecapan implementor } \\
\text { dalam pelaksanaan } \\
\text { kebijakan }\end{array}$ & 8 & 12 & 53 & 11 & 13 & 4 & 12.9 & 57.0 & 11.8 & 14.0 & 4.3 \\
\hline
\end{tabular}

\section{Sumber: Data Hasil Penelitian,2010}

Berdasarkan tabel 4.7 distribusi frekuensi faktor sumber daya, menggambarkan bahwa faktor sumber daya mempunyai peranan yang sangat penting dalam implementasi kebijakan. Karena sumber daya merupakan faktor kunci dalam setiap pelaksanan kebijakan. Hal ini tercermin dari hasil jawaban responden yang pada umumnya menyetujui atas pernyataan yang diajukan peneliti. Namun demikian, peneliti juga mencermati adanya sebagian kecil responden yang kurang menyetujui dan netral. Maka faktor sumber daya ini 
sangat penting dalam proses pelaksanaan implementasi kebijakan. Selain itu dapat dilihat dari hasil pengumpulan data yang mengacu pada kuesioner, diperoleh skor rentang nilai data untuk sumber daya yang diwakili oleh empat item pernyataan untuk sembilan puluh tiga responden. Rentang nilai diperoleh dari perkalian antara jumlah responden dengan empat item pernyataan, dan selanjutnya dikalikan dengan skor alternatif jawaban, sehingga diperoleh skor rentang nilai jawaban maksimum $\left(R_{\text {maks }}=1860\right)$, dan nilai jawaban minimum $\left(R_{\min }=372\right)$ sebagai berikut :

93 responden $\mathrm{x} 4$ item $\mathrm{x} 5=1860$

93 responden $\mathrm{x} 4$ item $\mathrm{x} 4=1488$

93 responden $\mathrm{x} 4$ item $\mathrm{x} 3=1116$

93 responden $\times 4$ item $\times 2=744$

93 responden $\mathrm{x} 4$ item $\mathrm{x} 1=372$

Hasil perhitungan tersebut memberikan gambaran bahwa faktor Sumber Daya mempunyai Rentang nilai pada hasil penelitian ini yang berdasarkan skor minimum dan skor maksimum jawaban responden yang telah dijelaskan di atas, dan perhitungan pada tabel yang menghasilkan total nilai skor $\Sigma \mathbf{f i}$. $\mathbf{X i}=1195$ digambarkan pada kontinum sebagai berikut: 


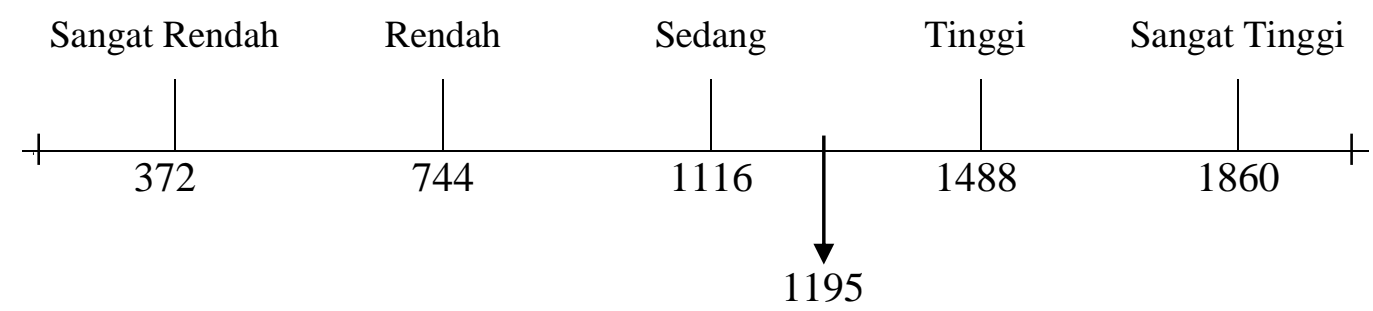

Gambar 4.2

Kontinum Faktor Sumber Daya

Mengacu pada gambar 4.2 kontinum Faktor Sumber Daya bahwa hasil perhitungan di atas yang tertera pada tabel 4.6 total skor Faktor Sumber daya menunjukan pada umumnya responden mengganggap penting Faktor Sumber daya dengan hasil skor jawaban responden $\Sigma \mathbf{f i} . \mathbf{X i}=1195$, dimana hasil tersebut berada pada tahapan antara kontinum sedang menuju ke tinggi. Sehingga dapat dikatakan bahwa faktor sumber daya dalam implementasi kebijakan ini sudah berjalan dengan efektif.

\subsubsection{Faktor Karakteristik Organisasi Pelaksana}

Faktor Karakteristik Organisasi Pelaksana meliputi dua indikator yaitu daya dukung struktur organisasi dan hubungan kumunikasi internal birokrasi, dan empat item pernyataan untuk Sembilan puluh tiga responden. Adapun hasil jawaban responden yang berkaitan dengan pernyataan yang diajukan dapat dilihat pada tabel 4.8 total skor faktor Karakteristik Organisasi Pelaksana sebagai berikut: 
Tabel 4.8

Total Skor faktor Karakteristik Organisasi Pelaksana

\begin{tabular}{|c|c|c|c|c|c|c|c|c|c|c|c|c|c|c|c|c|c|c|}
\hline \multirow{2}{*}{ No } & \multirow{2}{*}{ Pernyataan } & \multirow{2}{*}{ Kode } & \multicolumn{5}{|c|}{$\mathrm{Fi}$} & \multirow{2}{*}{\multicolumn{5}{|c|}{$\mathrm{Xi}$}} & \multirow{2}{*}{\multicolumn{5}{|c|}{ FixXi }} & \multirow{2}{*}{ Fi.Xi } \\
\hline & & & SS & $\mathrm{S}$ & $N$ & $\mathrm{TS}$ & STS & & & & & & & & & & & \\
\hline 1 & $\begin{array}{l}\text { Satuan Polisi Pamong } \\
\text { Praja mempunyai daya } \\
\text { dukung struktur organisasi } \\
\text { dalam proses pelaksanaan } \\
\text { kebijakan }\end{array}$ & 9 & 27 & 56 & 8 & 1 & 1 & 5 & 4 & 3 & 2 & 1 & 135 & 224 & 24 & 2 & 1 & 386 \\
\hline 2 & $\begin{array}{l}\text { Satuan Polisi Pamong } \\
\text { Praja kurang adanya daya } \\
\text { dukung struktur organisasi } \\
\text { dalam proses pelaksanaan } \\
\text { kebijakan }\end{array}$ & 10 & 13 & 51 & 19 & 7 & 3 & 1 & 2 & 3 & 4 & 5 & 13 & 102 & 57 & 28 & 15 & 215 \\
\hline 3 & $\begin{array}{lr}\text { Hubungan } & \text { dan } \\
\text { Komunikasi internal } \\
\text { birokrasi sangat penting } \\
\text { dalam proses pelaksanaan } \\
\text { kebijakan }\end{array}$ & 11 & 6 & 9 & 78 & 0 & 0 & 5 & 4 & 3 & 2 & 1 & 30 & 36 & 234 & 0 & 0 & 300 \\
\hline 4 & $\begin{array}{lr}\text { Hubungan } & \text { dan } \\
\text { Komunikasi internal } \\
\text { birokrasi tidak terlalu } \\
\text { penting dalam proses } \\
\text { pelaksanaan kebijakan }\end{array}$ & 12 & 9 & 27 & 56 & 1 & 0 & 1 & 2 & 3 & 4 & 5 & 9 & 54 & 168 & 4 & 0 & 235 \\
\hline & & & & & & & & & & & & & & & um & & & 1136 \\
\hline
\end{tabular}

\section{Sumber: Data Hasil Penelitian,2010}

Tabel 4.8 Total Skor Faktor Karakteristik Organisasi Pelaksana, menunjukkan perkalian antara jumlah jawaban responden untuk masing-masing item pernyataan yang memiliki alternatif jawaban Sangat Setuju (SS), Setuju (S), Netral (N), Tidak Setuju (TS), dan Sangat Tidak Setuju (STS) dengan nilai alternatif jawaban mengacu pada skor jawaban untuk item pernyataan yang positif dan negatif. Pernyataan pada prinsip ini menggunakan alternatif jawaban yang positif dan negatif. Pada kolom akhir diperoleh jumlah perkalian antara jumlah responden yang menjawab masing-masing alternatif jawaban dengan skor item pernyataan, dan penjumlahannya menghasilkan total skor kecenderungan jawaban untuk faktor Karakteristik Organisasi Pelaksana, yaitu sebesar $\Sigma \mathbf{f i} . \mathbf{X i}=1136$. 
Perhitungan Persentase jawaban responden dapat dilihat pada tabel 4.9

Disribusi Frekuensi faktor Karakteristik Organisasi Pelaksana, sebagai berikut :

Tabel 4.9

Distribusi Frekuensi Faktor Karakteristik Organisasi Pelaksana

\begin{tabular}{|c|c|c|c|c|c|c|c|c|c|c|c|c|}
\hline \multirow{2}{*}{ No. } & \multirow{2}{*}{ Pernyataan } & \multirow{2}{*}{ Kode } & \multicolumn{5}{|c|}{ Alternatif Jawaban } & \multirow{2}{*}{\multicolumn{5}{|c|}{ Presentase (\%) }} \\
\hline & & & SS & $\mathrm{S}$ & $\mathrm{N}$ & TS & STS & & & & & \\
\hline 1. & $\begin{array}{l}\text { Satuan Polisi Pamong } \\
\text { Praja mempunyai daya } \\
\text { dukung struktur organisasi } \\
\text { dalam proses pelaksanaan } \\
\text { kebijakan }\end{array}$ & 9 & 27 & 56 & 8 & 1 & 1 & 29.0 & 60.2 & 8.6 & 1.1 & 1.1 \\
\hline 2. & $\begin{array}{l}\text { Satuan Polisi Pamong } \\
\text { Praja kurang adanya daya } \\
\text { dukung struktur organisasi } \\
\text { dalam proses pelaksanaan } \\
\text { kebijakan }\end{array}$ & 10 & 13 & 51 & 19 & 7 & 3 & 14.0 & 54.8 & 20.4 & 7.5 & 3.2 \\
\hline 3. & $\begin{array}{lr}\text { Hubungan } & \text { dan } \\
\text { Komunikasi internal } \\
\text { birokrasi sangat penting } \\
\text { dalam proses pelaksanaan } \\
\text { kebijakan }\end{array}$ & 11 & 6 & 9 & 78 & 0 & 0 & 6.5 & 9.7 & 83.9 & 0.0 & 0.0 \\
\hline 4. & $\begin{array}{lr}\text { Hubungan } & \text { dan } \\
\text { Komunikasi } & \text { internal } \\
\text { birokrasi tidak terlalu } \\
\text { penting dalam proses } \\
\text { pelaksanaan kebijakan }\end{array}$ & 12 & 9 & 27 & 56 & 1 & 0 & 9.7 & 29.0 & 60.2 & 1.1 & 0.0 \\
\hline
\end{tabular}

\section{Sumber: Data Hasil Penelitian,2010}

Berdasarkan tabel 4.9, menggambarkan bahwa faktor Karakteristik

Organisasi Pelaksana mempunyai peranan yang sangat penting dalam implementasi kebijakan. Karena dalam proses pelaksanaan kebijakan daya dukung dari setiap struktur organisasi sangat diperlukan demi tercapainya tujuan yang optimal. Namun bila dilihat dari hasil data penelitian tersebut biasanya dari setiap pelaksanaan kebijakan hubungan birokrasi itu kurang maksimal, disebabkan adanya faktor kepentingan tujuan tertentu selain pencapian tujuan pelaksanaan kebijakan. Hal ini tercermin dari hasil jawaban responden yang pada umumnya menyetujui atas pernyataan yang diajukan peneliti. Akan tetapi, peneliti juga mencermati adanya sebagian responden yang kurang menyetujui dan lebih 
banyaknya netral. Selain itu dapat dilihat dari hasil pengumpulan data yang mengacu pada kuesioner, diperoleh skor rentang nilai data untuk faktor Karakteristik Organisasi Pelaksana yang diwakili oleh empat item pernyataan untuk sembilan puluh tiga responden. Rentang nilai diperoleh dari perkalian antara jumlah responden dengan empat item pernyataan, dan selanjutnya dikalikan dengan skor alternatif jawaban, sehingga diperoleh skor rentang nilai jawaban maksimum $\left(R_{\text {maks }}=1860\right)$, dan nilai jawaban minimum $\left(R_{\min }=372\right)$ sebagai berikut :

93 responden $\mathrm{x} 4$ item $\mathrm{x} 5=1860$

93 responden $\mathrm{x} 4$ item $\mathrm{x} 4=1488$

93 responden $\mathrm{x} 4$ item $\mathrm{x} 3=1116$

93 responden $\times 4$ item $\times 2=744$

93 responden $\mathrm{x} 4$ item $\mathrm{x} 1=372$

Hasil perhitungan tersebut memberikan gambaran bahwa faktor Karakteristik Organisasi Pelaksana mempunyai Rentang nilai pada hasil penelitian ini yang berdasarkan skor minimum dan skor maksimum jawaban responden yang telah dijelaskan di atas, dan perhitungan pada tabel yang menghasilkan total nilai skor $\Sigma \mathbf{f i} . \mathbf{X i}=1136$ digambarkan pada kontinum sebagai berikut: 


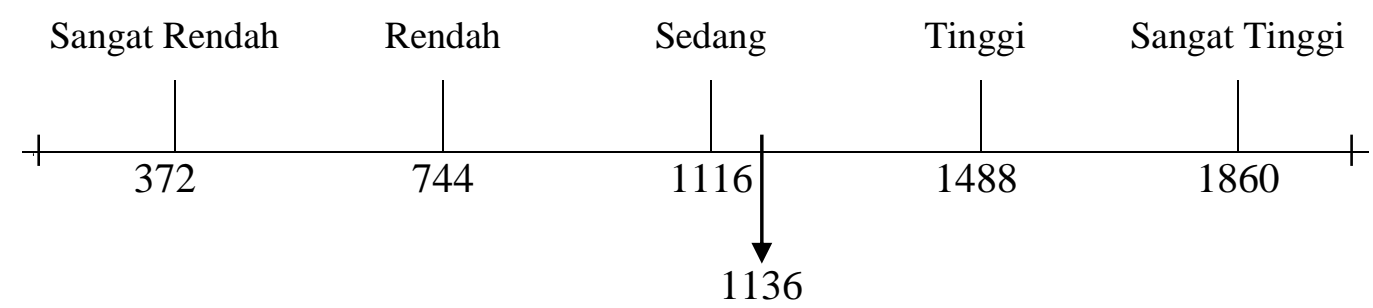

Gambar 4.3

Kontinum Faktor Karakteristik Organisasi Pelaksana

Mengacu pada gambar 4.3 bahwa pada umumnya responden menganggap sangat penting faktor Karakteristik Organisasi Pelaksana, dengan nilai skornya adalah $\Sigma \mathbf{f i} . \mathbf{X i}=1136$, dan skor ini berada di antara jawaban pada kriteria sedang menuju ke tinggi, sehingga dapat dikatakan bahwa faktor Sumber Daya dalam implementasi kebijakan faktor sumber daya sudah dilaksanakan secara efektif.

\subsubsection{Faktor Komunikasi antar Organisasi Pelaksana dan Kegiatan-}

\section{Kegiatan Pelaksanaan}

Faktor Komunikasi antar Organisasi Pelaksana dan Kegiatan-Kegiatan Pelaksanaan meliputi tiga indikator yaitu Koordinasi, Kerjasama,Standar Operating prosedur (SOP) dan enam item pernyataan untuk sembilan puluh tiga responden. Adapun hasil jawaban responden yang berkaitan dengan pernyataan yang diajukan dapat dilihat pada tabel 4.10 total skor Komunikasi antar Organisasi Pelaksana dan Kegiatan-Kegiatan Pelaksanaan sebagai berikut: 
Tabel 4.10

Total Skor faktor Komunikasi antar Organisasi Pelaksana dan KegiatanKegiatan Pelaksanaan

\begin{tabular}{|c|c|c|c|c|c|c|c|c|c|c|c|c|c|c|c|c|c|c|}
\hline \multirow{3}{*}{$\begin{array}{c}\text { No } \\
1\end{array}$} & \multirow{3}{*}{$\begin{array}{l}\text { Pernyataan } \\
\text { Satuan Polisi Pamong } \\
\text { Praja selalu berkoordinasi } \\
\text { dengan instansi lain untuk } \\
\text { mempemudahkan proses } \\
\text { pelaksanaan kebijakan }\end{array}$} & \multirow{3}{*}{$\begin{array}{c}\text { Kode } \\
13\end{array}$} & \multicolumn{5}{|c|}{$\mathrm{Fi}$} & \multirow{2}{*}{\multicolumn{5}{|c|}{$\mathrm{Xi}$}} & \multirow{2}{*}{\multicolumn{5}{|c|}{ FixXi }} & \multirow{3}{*}{ Fi.Xi } \\
\hline & & & \multirow{2}{*}{$\begin{array}{l}\text { SS } \\
29\end{array}$} & \multirow{2}{*}{$\begin{array}{l}S \\
49\end{array}$} & \multirow{2}{*}{$\begin{array}{l}\mathrm{N} \\
7 \\
7\end{array}$} & \multirow{2}{*}{$\begin{array}{c}\text { TS } \\
8\end{array}$} & \multirow{2}{*}{$\begin{array}{c}\text { STS } \\
0 \\
0\end{array}$} & & & & & & & & & & & \\
\hline & & & & & & & & 5 & 4 & 3 & 2 & 1 & 145 & 196 & 21 & 16 & 0 & \\
\hline 2 & $\begin{array}{lrr}\text { Satuan Polisi } & \text { Pamong } \\
\text { Praja tidak } & \text { harus } \\
\text { berkoordinasi } & \text { dengan } \\
\text { instansi lain } & \text { dalam } \\
\text { pelaksanaan kebijakan }\end{array}$ & 14 & 24 & 60 & 5 & 3 & 1 & 1 & 2 & 3 & 4 & 5 & 24 & 120 & 15 & 12 & 5 & 176 \\
\hline 3 & $\begin{array}{lr}\text { Adanya kerjasama yang } \\
\text { baik antara Satuan Polisi } \\
\text { Pamong Praja dengan } \\
\text { instansi lain dalam } \\
\text { pelaksanaan } & \\
\text { program/kebijakan } & \end{array}$ & 15 & 42 & 39 & 9 & 3 & 00 & 5 & 4 & 3 & 2 & 1 & 210 & 156 & 27 & 6 & 0 & 399 \\
\hline 4 & $\begin{array}{lrr}\text { Belum } & \text { adanya kerjasama } \\
\text { antara } & \text { Satuan } & \text { Polisi } \\
\text { Pamong } & \text { Praja } & \text { dengan } \\
\text { instansi } & \text { lain } & \text { dalam } \\
\text { pelaksanaan } & \\
\text { program/kebijakan } & \\
\end{array}$ & 16 & 30 & 48 & 8 & 6 & 1 & 1 & 2 & 3 & 4 & 5 & 30 & 96 & 24 & 24 & 5 & 179 \\
\hline 5 & $\begin{array}{l}\text { Satuan Polisi Pamong } \\
\text { Praja mengerti dan } \\
\text { memahami } \\
\text { adanya Standar Operating } \\
\text { Prosedur (SOP) }\end{array}$ & 17 & 19 & 56 & 14 & 3 & 1 & 5 & 4 & 3 & 2 & 1 & 95 & 224 & 42 & 6 & 1 & 368 \\
\hline 6 & $\begin{array}{lr}\text { Satuan Polisi } & \text { Pamong } \\
\text { Praja Kurang mengerti } \\
\text { dan memahami tentang } \\
\text { adanya Standar Operating } \\
\text { Prosedur (SOP) }\end{array}$ & 18 & 16 & 52 & 16 & 7 & 2 & 1 & 2 & 3 & 4 & 5 & 16 & 104 & 48 & 28 & 10 & 206 \\
\hline & & & & & & & & & & & & & & & JuI & & & 1706 \\
\hline
\end{tabular}

\section{Sumber: Data Hasil Penelitian,2010}

Tabel 4.10 Total Skor Faktor Komunikasi antar Organisasi Pelaksana dan Kegiatan-Kegiatan Pelaksanaan, menunjukkan perkalian antara jumlah jawaban responden untuk masing-masing item pernyataan yang memiliki alternatif jawaban Sangat Setuju (SS), Setuju (S), Netral (N), Tidak Setuju (TS), dan Sangat Tidak Setuju (STS) dengan nilai alternatif jawaban mengacu pada skor jawaban untuk item pernyataan yang positif dan negatif. Pernyataan pada prinsip ini 
menggunakan alternatif jawaban yang positif dan negatif. Pada kolom akhir diperoleh jumlah perkalian antara jumlah responden yang menjawab masingmasing alternatif jawaban dengan skor item pernyataan, dan penjumlahannya menghasilkan total skor kecenderungan jawaban untuk faktor Komunikasi antar Organisasi Pelaksana dan Kegiatan-Kegiatan Pelaksanaan, yaitu sebesar $\Sigma \mathbf{f i} . \mathbf{X i}=$ 1706.

Perhitungan Persentase jawaban responden dapat dilihat pada tabel 4.11 Disribusi Frekuensi faktor Komunikasi antar Organisasi Pelaksana dan KegiatanKegiatan Pelaksanaan, sebagai berikut :

Tabel 4.11

Distribusi Frekuensi Faktor Komunikasi antar Organisasi Pelaksana dan Kegiatan-Kegiatan Pelaksanaan

\begin{tabular}{|c|c|c|c|c|c|c|c|c|c|c|c|c|}
\hline \multirow{2}{*}{ No. } & \multirow{2}{*}{ Pernyataan } & \multirow{2}{*}{ Kode } & \multicolumn{5}{|c|}{ Alternatif Jawaban } & \multirow{2}{*}{\multicolumn{5}{|c|}{ Presentase (\%) }} \\
\hline & & & SS & $\mathrm{S}$ & $\mathrm{N}$ & TS & STS & & & & & \\
\hline 1. & $\begin{array}{l}\text { Satuan Polisi Pamong } \\
\text { Praja selalu berkoordinasi } \\
\text { dengan instansi lain untuk } \\
\text { mempemudahkan proses } \\
\text { pelaksanaan kebijakan }\end{array}$ & 13 & 29 & 49 & 7 & 8 & 0 & 31.2 & 52.7 & 7.5 & 8.6 & 0.0 \\
\hline 2. & $\begin{array}{lrr}\text { Satuan Polisi } & \text { Pamong } \\
\text { Praja tidak } & \text { harus } \\
\text { berkoordinasi } & \text { dengan } \\
\text { instansi lain dalam } & \text { delaksanaan kebijakan }\end{array}$ & 14 & 24 & 60 & 5 & 3 & 1 & 25.8 & 64.5 & 5.4 & 3.2 & 1.1 \\
\hline 3. & $\begin{array}{l}\text { Adanya kerjasama yang } \\
\text { baik antara Satuan Polisi } \\
\text { Pamong Praja dengan } \\
\text { instansi lain dalam } \\
\text { pelaksanaan } \\
\text { program/kebijakan }\end{array}$ & 15 & 42 & 39 & 9 & 3 & 0 & 45.2 & 41.9 & 9.7 & 3.2 & 0.0 \\
\hline 4. & $\begin{array}{lrr}\text { Belum adanya kerjasama } \\
\text { antara Satuan } & \text { Polisi } \\
\text { Pamong Praja dengan } \\
\text { instansi lain } & \text { dalam } \\
\text { pelaksanaan } & \\
\text { program/kebijakan } & \\
\end{array}$ & 16 & 30 & 48 & 8 & 6 & 1 & 32.3 & 51.6 & 8.6 & 6.5 & 1.1 \\
\hline 5. & 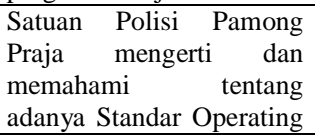 & 17 & 19 & 56 & 14 & 3 & 1 & 20.4 & 60.2 & 15.1 & 3.2 & 1.1 \\
\hline
\end{tabular}




\begin{tabular}{|c|l|c|c|c|c|c|c|c|c|c|c|c|}
\hline & Prosedur (SOP) & & & & & & & & & & & \\
\hline 6. & $\begin{array}{l}\text { Satuan Polisi Pamong } \\
\text { Praja Kurang mengerti } \\
\text { dan memahami tentang } \\
\text { adanya Standar Operating } \\
\text { Prosedur (SOP) }\end{array}$ & 18 & 16 & 52 & 16 & 7 & 2 & 17.2 & 55.9 & 17.2 & 7.5 & 2.2 \\
\hline
\end{tabular}

\section{Sumber: Data Hasil Penelitian,2010}

Berdasarkan tabel 4.11, menggambarkan bahwa faktor Komunikasi antar Organisasi Pelaksana dan Kegiatan-Kegiatan Pelaksanaan mempunyai peranan yang sangat penting dalam implementasi kebijakan. Satuan Polisi Pamong Praja dalam hal pelaksanaan kebijakannya belum sepenuhnya melibatkan semua unit kerja atau instansi lain yang terkait dengan implementasi kebijakan ini ternyata belum sepenuhnya dilibatkan, bisa saja disebabkan oleh kurangnya koordinasi dan adanya keterbatasan waktu dalam melaksanakan isi kebijakan ini..

Hal ini tercermin dari hasil jawaban responden yang pada umumnya menyetujui atas pernyataan yang diajukan peneliti. Namun demikian, peneliti juga mencermati adanya sebagian kecil responden yang kurang menyetujui dan netral.. Selain itu dapat dilihat dari hasil pengumpulan data yang mengacu pada kuesioner, diperoleh skor rentang nilai data untuk faktor Komunikasi antar Organisasi Pelaksana dan Kegiatan-Kegiatan Pelaksanaan yang diwakili oleh 6 item pernyataan untuk 93 responden. Rentang nilai diperoleh dari perkalian antara jumlah responden dengan 6 item pernyataan, dan selanjutnya dikalikan dengan skor alternatif jawaban, sehingga diperoleh skor rentang nilai jawaban maksimum $\left(R_{\text {maks }}=2790\right)$, dan nilai jawaban minimum $\left(R_{\min }=558\right)$ sebagai berikut :

93 responden $\times 6$ item $\times 5=2790$

93 responden $\mathrm{x} 6$ item $\mathrm{x} 4=2232$ 
93 responden $\times 6$ item x $3=1674$

93 responden x 6 item x $2=1116$

93 responden $\times 6$ item $\times 1=558$

Hasil perhitungan tersebut memberikan gambaran bahwa Komunikasi antar Organisasi Pelaksana dan Kegiatan-Kegiatan Pelaksanaan mempunyai Rentang nilai pada hasil penelitian ini yang berdasarkan skor minimum dan skor maksimum jawaban responden yang telah dijelaskan di atas, dan perhitungan pada tabel yang menghasilkan total nilai skor $\Sigma \mathbf{f i} . \mathbf{X i}=1706$ digambarkan pada kontinum sebagai berikut:

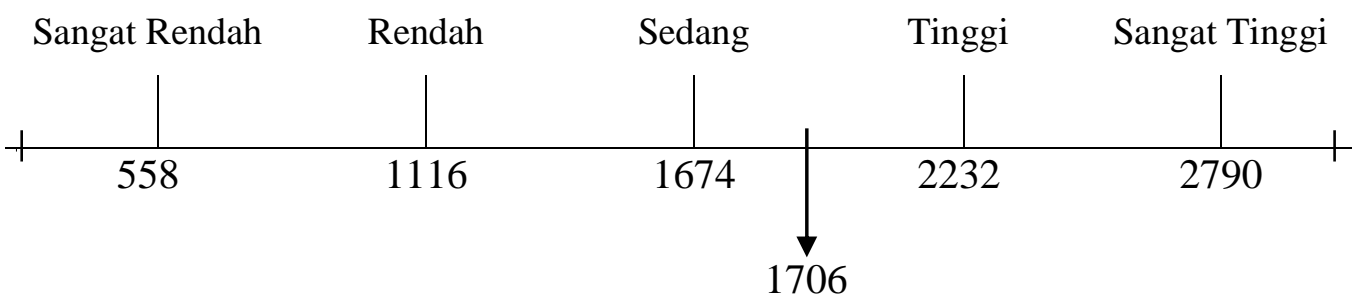

Gambar 4.4

Kontinum Faktor Komunikasi antar Organisasi Pelaksana dan Kegiatan-Kegiatan Pelaksanaan

Mengacu pada gambar 4.4 kontinum Faktor komunikasi antar organisasi pelaksana dan kegiatan-kegiatan pelaksnaan, bahwa sesuai dengan hasil perhitungan di atas yang tertera pada tabel 4.10 total skor Faktor komunikasi antar organisasi pelaksana dan kegiatan-kegiatan pelaksanaan, menunjukan pada umumnya responden mengganggap penting Faktor komunikasi antar organisasi pelaksana dan kegiatan-kegiatan pelaksanaan dengan hasil skor jawaban 
responden $\Sigma \mathbf{f i}$. $\mathbf{X i}=1706$, berarti pada gambar 4.4 menggambarkan tahapan antara kontinum sedang menuju ke tinggi.

\subsubsection{Faktor Sikap Para Pelaksana}

Faktor Sikap Para Pelaksana meliputi tiga indikator yaitu demokratis, antusias, responsif dan enam item pernyataan untuk sembilan puluh tiga responden. Adapun hasil jawaban responden yang berkaitan dengan pernyataan yang diajukan dapat dilihat pada tabel 4.12 total skor Sikap Para Pelaksana sebagai berikut:

Tabel 4.12

Total Skor faktor Sikap Para Pelaksana

\begin{tabular}{|c|c|c|c|c|c|c|c|c|c|c|c|c|c|c|c|c|c|c|}
\hline \multirow{3}{*}{$\begin{array}{c}\text { No } \\
1\end{array}$} & \multirow{3}{*}{$\begin{array}{l}\text { Pernyataan } \\
\text { Satuan Polisi Pamong } \\
\text { Praja selalu demokratis } \\
\text { dalam pelaksanaan } \\
\text { kebijakannya }\end{array}$} & \multirow{3}{*}{$\begin{array}{c}\text { Kode } \\
19\end{array}$} & \multicolumn{5}{|c|}{$\mathrm{Fi}$} & \multirow{2}{*}{\multicolumn{5}{|c|}{$\mathrm{Xi}$}} & \multirow{2}{*}{\multicolumn{5}{|c|}{ FixXi }} & \multirow{3}{*}{$\begin{array}{r}\text { Fi.Xi } \\
336\end{array}$} \\
\hline & & & \multirow{2}{*}{\begin{tabular}{|l|} 
SS \\
19
\end{tabular}} & \multirow{2}{*}{$\begin{array}{l}\mathrm{S} \\
40\end{array}$} & \multirow{2}{*}{$\begin{array}{l}\mathrm{N} \\
18\end{array}$} & \multirow{2}{*}{$\begin{array}{l}\text { TS } \\
11\end{array}$} & \multirow{2}{*}{$\begin{array}{c}\text { STS } \\
5\end{array}$} & & & & & & & & & & & \\
\hline & & & & & & & & 5 & 4 & 3 & 2 & 1 & 95 & 160 & 54 & 22 & 5 & \\
\hline 2 & $\begin{array}{lrr}\text { Satuan } & \text { Polisi } & \text { Pamong } \\
\text { Praja tidak } & \text { selalu } \\
\text { demokratis } & \text { dalam } \\
\text { pelaksanaan kebijakannya }\end{array}$ & 20 & 18 & 37 & 16 & 11 & 11 & 1 & 2 & 3 & 4 & 5 & 18 & 74 & 48 & 44 & 55 & 239 \\
\hline 3 & $\begin{array}{lrr}\text { Satuan } & \text { Polisi } & \text { Pamong } \\
\text { Praja memiliki } & \text { antusias } \\
\text { tinggi dan } & \text { senantiasa } \\
\text { bertahan di } & \text { antara } \\
\text { hambatan yang } & \text { ditemui } \\
\text { dalam } & \text { pelaksanaan } \\
\text { kebijakan } & & \end{array}$ & 21 & 16 & 60 & 11 & 3 & 3 & 5 & 4 & 3 & 2 & 1 & 80 & 240 & 33 & 6 & 3 & 362 \\
\hline 4 & \begin{tabular}{lcr} 
Satuan & Polisi & Pamong \\
Praja & tidak & memiliki \\
antusias & tinggi & dan \\
senantiasa & & kurang \\
bertahan & di & antara \\
hambatan & yang & ditemui \\
dalam & \multicolumn{2}{c}{ pelaksanaan } \\
kebijakan & \multicolumn{2}{c}{} \\
\end{tabular} & 22 & 17 & 63 & 9 & 3 & 1 & 1 & 2 & 3 & 4 & 5 & 17 & 126 & 27 & 12 & 5 & 187 \\
\hline 5 & $\begin{array}{lcr}\text { Satuan } & \text { Polisi } & \text { Pamong } \\
\text { Praja } & \text { selalu } & \text { Responsif } \\
\text { dalam } & \text { melaksanakan } \\
\text { kebijakannya }\end{array}$ & 23 & 11 & 72 & 10 & 0 & 0 & 5 & 4 & 3 & 2 & 1 & 55 & 288 & 30 & 0 & 0 & 373 \\
\hline 6 & $\begin{array}{lrr}\text { Satuan } & \text { Polisi } & \text { Pamong } \\
\text { Praja } & \text { kurang } & \text { responsif } \\
\text { dalam } & \text { melaksanakan } \\
\text { kebijakannya }\end{array}$ & 24 & 12 & 66 & 13 & 2 & 0 & 1 & 2 & 3 & 4 & 5 & 12 & 132 & 39 & 8 & 0 & 191 \\
\hline & & & & & & & & & & & & & & & & lah & & 1688 \\
\hline
\end{tabular}

Sumber: Data Hasil Penelitian,2010 
Tabel 4.12 Total Skor Faktor Sikap Para Pelaksana, menunjukkan perkalian antara jumlah jawaban responden untuk masing-masing item pernyataan yang memiliki alternatif jawaban Sangat Setuju (SS), Setuju (S), Netral (N), Tidak Setuju (TS), dan Sangat Tidak Setuju (STS) dengan nilai alternatif jawaban mengacu pada skor jawaban untuk item pernyataan yang positif dan negatif. Pernyataan pada prinsip ini menggunakan alternatif jawaban yang positif dan negatif. Pada kolom akhir diperoleh jumlah perkalian antara jumlah responden yang menjawab masing-masing alternatif jawaban dengan skor item pernyataan, dan penjumlahannya menghasilkan total skor kecenderungan jawaban untuk faktor Sikap Para Pelaksana, yaitu sebesar $\Sigma \mathbf{f i} . \mathbf{X i}=1688$ Perhitungan Persentase jawaban responden dapat dilihat pada tabel 4.13 Disribusi Frekuensi Sikap Para Pelaksana, sebagai berikut :

Tabel 4.13

Distribusi Frekuensi Faktor Sikap Para Pelaksana

\begin{tabular}{|c|c|c|c|c|c|c|c|c|c|c|c|c|}
\hline \multirow{2}{*}{ No. } & \multirow{2}{*}{ Pernyataan } & \multirow{2}{*}{ Kode } & \multicolumn{5}{|c|}{ Alternatif Jawaban } & \multirow{2}{*}{\multicolumn{5}{|c|}{ Presentase $(\%)$}} \\
\hline & & & SS & $\mathrm{S}$ & $\mathrm{N}$ & TS & STS & & & & & \\
\hline 1. & $\begin{array}{lr}\text { Satuan Polisi } & \text { Pamong } \\
\text { Praja selalu demokratis } \\
\text { dalam } & \text { pelaksanaan } \\
\text { kebijakannya } & \\
\end{array}$ & 19 & 19 & 40 & 18 & 11 & 5 & 20.4 & 43.0 & 19.4 & 11.8 & 5.4 \\
\hline 2. & $\begin{array}{lrr}\text { Satuan } & \text { Polisi } & \text { Pamong } \\
\text { Praja } & \text { tidak } & \text { selalu } \\
\text { demokratis } & \text { dalam } \\
\text { pelaksanaan kebijakannya }\end{array}$ & 20 & 18 & 37 & 16 & 11 & 11 & 19.4 & 39.8 & 17.2 & 11.8 & 11.8 \\
\hline 3. & $\begin{array}{lrr}\text { Satuan } & \text { Polisi } & \text { Pamong } \\
\text { Praja } & \text { memiliki } & \text { antusias } \\
\text { tinggi dan } & \text { senantiasa } \\
\text { bertahan } & \text { di } & \text { antara } \\
\text { hambatan } & \text { yang } & \text { ditemui } \\
\text { dalam } & \text { pelaksanaan } \\
\text { kebijakan } & & \end{array}$ & 21 & 16 & 60 & 11 & 3 & 3 & 17.2 & 64.5 & 11.8 & 3.2 & 3.2 \\
\hline 4. & \begin{tabular}{lrr} 
Satuan & Polisi & Pamong \\
Praja & tidak & memiliki \\
antusias & tinggi & dan \\
senantiasa & & kurang \\
bertahan & di & antara \\
hambatan & yang & ditemui \\
dalam & \multicolumn{2}{rl}{ pelaksanaan } \\
kebijakan & & \\
\end{tabular} & 22 & 17 & 63 & 9 & 3 & 1 & 18.3 & 67.7 & 9.7 & 3.2 & 1.1 \\
\hline
\end{tabular}




\begin{tabular}{|c|l|c|c|c|c|c|c|c|c|c|c|c|}
\hline 5. & $\begin{array}{l}\text { Satuan Polisi Pamong } \\
\text { Praja selalu Responsif } \\
\text { dalam melaksanakan } \\
\text { kebijakannya }\end{array}$ & 23 & 11 & 72 & 10 & 0 & 0 & 11.8 & 77.4 & 10.8 & 0.0 & 0.0 \\
\hline 6. & $\begin{array}{l}\text { Satuan Polisi Pamong } \\
\text { Praja kurang responsif } \\
\text { dalam melaksanakan } \\
\text { kebijakannya }\end{array}$ & 24 & 12 & 66 & 13 & 2 & 0 & 12.9 & 71.0 & 14.0 & 2.2 & 0.0 \\
\hline
\end{tabular}

\section{Sumber: Data Hasil Penelitian,2010}

Berdasarkan tabel 4.13, menggambarkan bahwa Sikap Para Pelaksana mempunyai peranan yang sangat penting dalam implementasi kebijakan. Peranan para pelaksana yaitu satuan polisi pamong praja, merupakan peranan yang sangat penting dalam melaksanakan kebijakan, tertutama proses pelaksanaanya yang selalu berbenturan dengan publik. Bila dilihat lebih mendalam ternyata disebabkan minimnya pengetahuan pelaksana kebijakan, masihnya adanya beberapa pegawai yang belum memahami dari isi kebijakan dan sikap para pelaksana belum mempunyai pendidikan dan pelatihan yang handal. Hal ini tercermin dari hasil jawaban responden yang pada umumnya menyetujui atas pernyataan yang diajukan peneliti. Namun demikian, peneliti juga mencermati adanya sebagian kecil responden yang kurang menyetujui dan netral. Selain itu dapat dilihat dari hasil pengumpulan data yang mengacu pada kuesioner, diperoleh skor rentang nilai data untuk faktor Sikap Para Pelaksana yang diwakili oleh enam item pernyataan untuk embilan puluh tiga responden. Rentang nilai diperoleh dari perkalian antara jumlah responden dengan 6 item pernyataan, dan selanjutnya dikalikan dengan skor alternatif jawaban, sehingga diperoleh skor rentang nilai jawaban maksimum $\left(\mathrm{R}_{\text {maks }}=2790\right)$, dan nilai jawaban minimum $\left(\mathrm{R}_{\min }=558\right)$ sebagai berikut : 
93 responden x 6 item x $5=2790$

93 responden $\times 6$ item $\times 4=2232$

93 responden x 6 item x $3=1674$

93 responden $\times 6$ item $\times 2=1116$

93 responden $\times 6$ item $\times 1=558$

Hasil perhitungan tersebut memberikan gambaran bahwa Sikap Para Pelaksana mempunyai Rentang nilai pada hasil penelitian ini yang berdasarkan skor minimum dan skor maksimum jawaban responden yang telah dijelaskan di atas, dan perhitungan pada tabel yang menghasilkan total nilai skor $\Sigma \mathbf{f i} . \mathbf{X i}=1688$ digambarkan pada kontinum sebagai berikut:

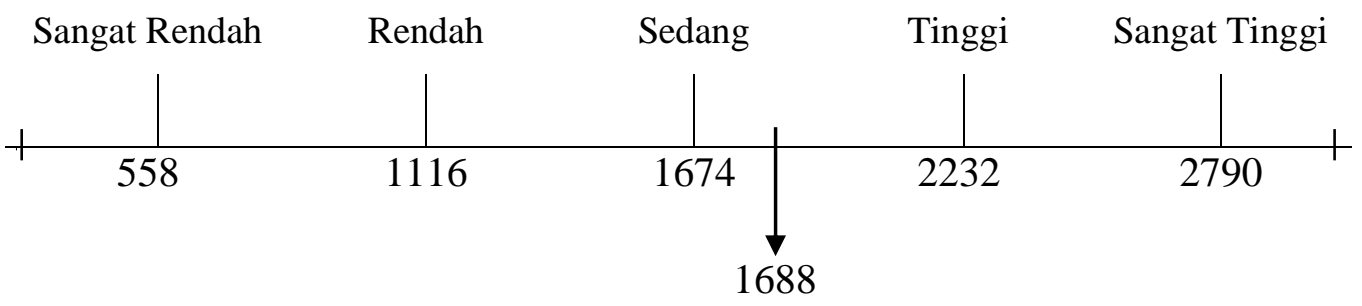

Gambar 4.5

Kontinum Faktor Sikap Para Pelaksana

Mengacu pada gambar 4.5 kontinum Faktor Sikap Para Pelaksana, bahwa sesuai dengan hasil perhitungan di atas yang tertera pada tabel 4.12 total skor Faktor Sikap Para Pelaksana, menunjukan pada umumnya responden mengganggap penting Faktor Sikap Para Pelaksana dengan hasil skor jawaban responden $\Sigma \mathbf{f i} . \mathbf{X i}=1688$, berarti pada gambar 4.4 menunjukan tahapan antara kontinum sedang menuju ke tinggi. 


\subsubsection{Faktor Lingkungan Sosial, Ekonomi, dan Politik}

Faktor Lingkungan Sosial, Ekonomi, dan Politik meliputi dua indikator yaitu Elite politik, kelompok-kelompok kepentingan dan empat item pernyataan untuk sembilan puluh tiga responden. Adapun hasil jawaban responden yang berkaitan dengan pernyataan yang diajukan dapat dilihat pada tabel 4.14 total skor Lingkungan Sosial, Ekonomi, dan Politik sebagai berikut :

Tabel 4.14

Total Skor faktor Lingkungan Sosial, Ekonomi, dan Politik

\begin{tabular}{|c|c|c|c|c|c|c|c|c|c|c|c|c|c|c|c|c|c|c|}
\hline \multirow{2}{*}{ No } & \multirow{2}{*}{ Pernyataan } & \multirow{2}{*}{ Kode } & \multicolumn{5}{|c|}{$\mathrm{Fi}$} & \multirow{2}{*}{\multicolumn{5}{|c|}{$\mathrm{Xi}$}} & \multirow{2}{*}{\multicolumn{5}{|c|}{ FixXi }} & \multirow{2}{*}{ Fi.Xi } \\
\hline & & & SS & $\mathrm{S}$ & $\mathrm{N}$ & $\mathrm{TS}$ & STS & & & & & & & & & & & \\
\hline 1 & $\begin{array}{l}\text { Satuan Polisi Pamong } \\
\text { Praja dengan elite politik } \\
\text { sudah } \quad \text { sepenuhnya } \\
\text { mendukung pelaksanaan } \\
\text { program / kebijakan } \\
\end{array}$ & 25 & 10 & 48 & 31 & 3 & 1 & 5 & 4 & 3 & 2 & 1 & 50 & 192 & 93 & 6 & 1 & 342 \\
\hline 2 & $\begin{array}{l}\text { Satuan Polisi Pamong } \\
\text { Praja dengan elite politik } \\
\text { belum } \quad \text { sepenuhnya } \\
\text { mendukung pelaksanaan } \\
\text { program / kebijakan }\end{array}$ & 26 & 5 & 42 & 36 & 7 & 3 & 1 & 2 & 3 & 4 & 5 & 5 & 84 & 108 & 28 & 15 & 240 \\
\hline 3 & $\begin{array}{lr}\text { Satuan Polisi } & \text { Pamong } \\
\text { Praja dengan } & \text { Kelompok- } \\
\text { kelompok } & \text { kepentingan } \\
\text { tertentu } & \text { memberikan } \\
\text { dukungan } & \text { dan } \\
\text { mempermudah } & \\
\text { pelaksanaan kebijakan }\end{array}$ & 27 & 6 & 47 & 22 & 16 & 2 & 5 & 4 & 3 & 2 & 1 & 30 & 188 & 66 & 32 & 2 & 318 \\
\hline 4 & $\begin{array}{lr}\text { Satuan Polisi } & \text { Pamong } \\
\text { Praja dengan } & \text { Kelompok- } \\
\text { kelompok } & \text { kepentingan } \\
\text { tertentu tidak } & \text { memberikan } \\
\text { dukungan } & \text { dalam } \\
\text { pelaksanaan } & \text { kebijakan } \\
\text { tetapi } & \text { malah } \\
\text { memperlambat kebijakan }\end{array}$ & 28 & 9 & 53 & 15 & 11 & 5 & 1 & 2 & 3 & 4 & 5 & 9 & 106 & 45 & 44 & 25 & 229 \\
\hline & & & & & & & & & & & & & & & Jum & & & 1129 \\
\hline
\end{tabular}

\section{Sumber: Data Hasil Penelitian,2010}

Tabel 4.14 Total Skor Faktor Lingkungan Sosial, Ekonomi, dan Politik, menunjukkan perkalian antara jumlah jawaban responden untuk masing-masing item pernyataan yang memiliki alternatif jawaban Sangat Setuju (SS), Setuju (S), 
Netral (N), Tidak Setuju (TS), dan Sangat Tidak Setuju (STS) dengan nilai alternatif jawaban mengacu pada skor jawaban untuk item pernyataan yang positif dan negatif. Pernyataan pada prinsip ini menggunakan alternatif jawaban yang positif dan negatif. Pada kolom akhir diperoleh jumlah perkalian antara jumlah responden yang menjawab masing-masing alternatif jawaban dengan skor item pernyataan, dan penjumlahannya menghasilkan total skor kecenderungan jawaban untuk faktor Lingkungan Sosial, Ekonomi, dan Politik, yaitu sebesar $\Sigma$ fi. $\mathbf{X i}=$ 1129.

Perhitungan Persentase jawaban responden dapat dilihat pada tabel 4.15. Disribusi Frekuensi Lingkungan Sosial, Ekonomi, dan Politik, sebagai berikut :

Tabel 4.15

Distribusi Frekuensi Faktor Lingkungan Sosial, Ekonomi, dan Politik

\begin{tabular}{|c|c|c|c|c|c|c|c|c|c|c|c|c|}
\hline \multirow{2}{*}{ No. } & \multirow{2}{*}{ Pernyataan } & \multirow{2}{*}{ Kode } & \multicolumn{5}{|c|}{ Alternatif Jawaban } & \multirow{2}{*}{\multicolumn{5}{|c|}{ Presentase (\%) }} \\
\hline & & & SS & $\mathrm{S}$ & $\mathrm{N}$ & TS & STS & & & & & \\
\hline 1. & $\begin{array}{l}\text { Satuan Polisi Pamong } \\
\text { Praja dengan elite politik } \\
\text { sudah r sepenuhnya } \\
\text { mendukung pelaksanaan } \\
\text { program / kebijakan }\end{array}$ & 25 & 10 & 48 & 31 & 3 & 1 & 10.8 & 51.6 & 33.3 & 3.2 & 1.1 \\
\hline 2. & $\begin{array}{l}\text { Satuan Polisi Pamong } \\
\text { Praja dengan elite politik } \\
\text { belum repenuhnya } \\
\text { mendukung pelaksanaan } \\
\text { program / kebijakan }\end{array}$ & 26 & 5 & 42 & 36 & 7 & 3 & 5.4 & 45.2 & 38.7 & 7.5 & 3.2 \\
\hline 3. & $\begin{array}{l}\text { Satuan Polisi } \text { Pamong } \\
\text { Praja dengan Kelompok- } \\
\text { kelompok kepentingan } \\
\text { tertentu memberikan } \\
\text { dukungan } \\
\text { mempermudah } \\
\text { pelaksanaan kebijakan }\end{array}$ & 27 & 6 & 47 & 22 & 16 & 2 & 6.5 & 50.5 & 23.7 & 17.2 & 2.2 \\
\hline 4. & $\begin{array}{lr}\text { Satuan Polisi } & \text { Pamong } \\
\text { Praja dengan } & \text { Kelompok- } \\
\text { kelompok } & \text { kepentingan } \\
\text { tertentu tidak } & \text { memberikan } \\
\text { dukungan } & \text { dalam } \\
\text { pelaksanaan } & \text { kebijakan } \\
\text { tetapi r } & \text { malah } \\
\text { memperlambat kebijakan } \\
\end{array}$ & 28 & 9 & 53 & 15 & 11 & 5 & 9.7 & 57.0 & 16.1 & 11.8 & 5.4 \\
\hline
\end{tabular}

Sumber: Data Hasil Penelitian,2010 
Berdasarkan tabel 4.15, menggambarkan bahwa faktor Lingkungan Sosial, Ekonomi, dan Politik mempunyai peranan yang sangat penting dalam implementasi kebijakan. Karena dalam proses pelaksanaan kebijakan satuan polisi pamong praja harus bisa memperhitungkan dari setiap aspek lingkungan sosial, ekonomi dan politik sangat diperlukan demi tercapainya tujuan yang optimal. Namun bila dilihat dari hasil data penelitian tersebut biasanya dari setiap pelaksanaan kebijakan hubungan lingkungan sosial, ekonomi, dan politik itu kurang maksimal, disebabkan adanya faktor kepentingan tujuan tertentu selain pencapian tujuan pelaksanaan kebijakan dan tampak terlihat jelas dari aspek elit politik. Hal ini tercermin dari hasil jawaban responden yang pada umumnya menyetujui atas pernyataan yang diajukan peneliti. Akan tetapi, peneliti juga mencermati adanya sebagian responden yang kurang menyetujui dan lebih banyaknya netral. Hal ini dapat dilihat dari hasil pengumpulan data yang mengacu pada kuesioner, diperoleh skor rentang nilai data untuk faktor standar dan sasaran kebijakan yang diwakili oleh empat item pernyataan untuk sembilan puluh tiga responden. Rentang nilai diperoleh dari perkalian antara jumlah responden dengan empat item pernyataan, dan selanjutnya dikalikan dengan skor alternatif jawaban, sehingga diperoleh skor rentang nilai jawaban maksimum $\left(\mathrm{R}_{\text {maks }}=1860\right)$, dan nilai jawaban minimum $\left(\mathrm{R}_{\min }=372\right)$ sebagai berikut :

93 responden $\mathrm{x} 4$ item $\mathrm{x} 5=1860$

93 responden $\mathrm{x} 4$ item x $4=1488$

93 responden $\mathrm{x} 4$ item $\mathrm{x} 3=1116$ 
93 responden $\mathrm{x} 4$ item $\mathrm{x} 2=744$

93 responden $\mathrm{x} 4$ item $\mathrm{x} 1=372$

Hasil perhitungan tersebut memberikan gambaran bahwa faktor Lingkungan Sosial, Ekonomi, dan Politik mempunyai Rentang nilai pada hasil penelitian ini yang berdasarkan skor minimum dan skor maksimum jawaban responden yang telah dijelaskan di atas, dan perhitungan pada tabel yang menghasilkan total nilai skor $\Sigma \mathbf{f i} . \mathbf{X i}=1129$ digambarkan pada kontinum sebagai berikut:

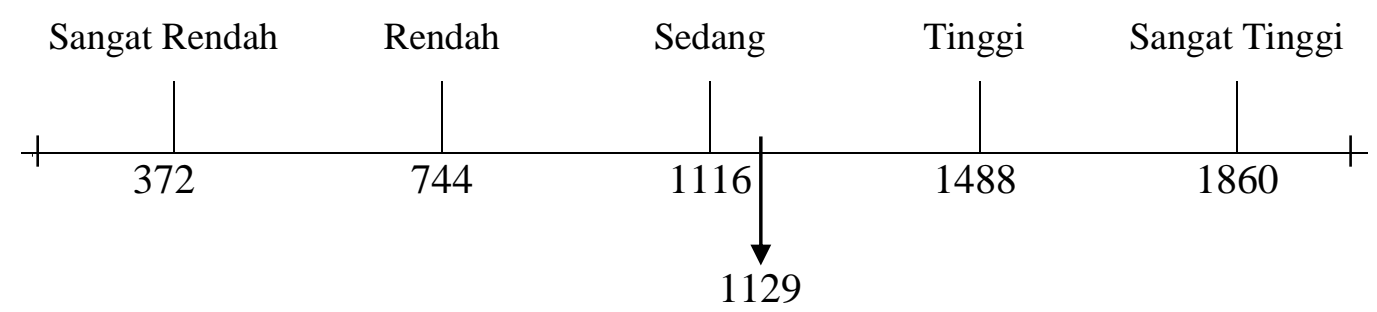

Gambar 4.6

Kontinum Faktor Lingkungan Sosial, Ekonomi, dan Politik

Mengacu pada gambar 4.6 kontinum Faktor Lingkungan Sosial, Ekonomi, dan Politik, bahwa sesuai dengan hasil perhitungan di atas yang tertera pada tabel 4.12 total skor Faktor Lingkungan Sosial, Ekonomi, dan Politik, menunjukan pada umumnya responden mengganggap penting Faktor Lingkungan Sosial, Ekonomi, dan Politik dengan hasil skor jawaban responden $\Sigma \mathbf{f i} . \mathbf{X i}=1129$, berarti pada gambar 4.4 menunjukan tahapan antara kontinum sedang menuju ke tinggi. 


\subsubsection{Variabel Kinerja Pegawai}

Variabel kinerja pegawai ini mempunyai empat dimensi-dimensi kinerja pegawai yaitu Kualitas Keja (Y1), Kuantitas Kerja (Y2), Keandalan (Y3), dan Sikap (Y4), dari empat dimensi tersebut diwaklili oleh tiga puluh item pernyataan yang berbentuk positif dan negatif atau lebih di kenal dengan nama skla lingkert. Peneliti selebihnya akan menjabarkan dari hasil penelitiannya, sebagai berikut :

\subsubsection{Dimensi Kualitas Kerja}

Dimensi kualitas kerja meliputi empat indikator, yaitu ketepatan, keterlitian, keterampilan, keberhasilan yang teridiri dari delapan item pernyataan positif dan negatif untuk sembilan puluh tiga responden. Untuk mengetahui hasil tanggapan responden dimensi kualitas kerja dapat dilihat tabel 4.16 total skor dimensi kulitas kerja, sebagai berikut :

Tabel 4.16

Total Skor Dimensi Kualitas Kerja

\begin{tabular}{|c|c|c|c|c|c|c|c|c|c|c|c|c|c|c|c|c|c|c|}
\hline \multirow{3}{*}{$\begin{array}{c}\text { No } \\
1\end{array}$} & \multirow{3}{*}{ 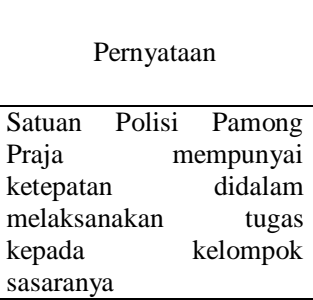 } & \multirow{3}{*}{$\begin{array}{c}\text { Kode } \\
29\end{array}$} & \multicolumn{5}{|c|}{$\mathrm{Fi}$} & \multirow{2}{*}{\multicolumn{5}{|c|}{$\mathrm{Xi}$}} & \multirow{2}{*}{\multicolumn{5}{|c|}{ FixXi }} & \multirow{3}{*}{ Fi.Xi } \\
\hline & & & \multirow{2}{*}{\begin{tabular}{|r|} 
SS \\
23
\end{tabular}} & \multirow{2}{*}{$\begin{array}{l}\mathrm{S} \\
58\end{array}$} & \multirow{2}{*}{$\begin{array}{l}\mathrm{N} \\
4\end{array}$} & \multirow{2}{*}{$\begin{array}{c}\text { TS } \\
6\end{array}$} & \multirow{2}{*}{$\begin{array}{c}\text { STS } \\
2\end{array}$} & & & & & & & & & & & \\
\hline & & & & & & & & 5 & 4 & 3 & 2 & 1 & 115 & 232 & 12 & 12 & 2 & \\
\hline 2 & $\begin{array}{l}\text { Satuan Polisi Pamong } \\
\text { Praja kurang mempunyai } \\
\text { ketepatan kepada } \\
\text { kelompok sasaran didalam } \\
\text { melaksanakan tugasnya }\end{array}$ & 30 & 26 & 57 & 9 & 4 & 1 & 1 & 2 & 3 & 4 & 5 & 26 & 114 & 27 & 16 & 5 & 188 \\
\hline 3 & $\begin{array}{lr}\text { Satuan Polisi } & \text { Pamong } \\
\text { Praja } & \text { selalu } \\
\text { memperhitungkan } & \text { faktor } \\
\text { ketelitiannya } & \text { terlebih } \\
\text { dahulu } & \text { sebelum } \\
\text { melaksanakan } & \\
\text { pekerjaannya } & \\
\end{array}$ & 31 & 35 & 54 & 4 & 0 & 0 & 5 & 4 & 3 & 2 & 1 & 175 & 216 & 12 & 0 & 0 & 403 \\
\hline 4 & Satuan Polisi Pamong & 32 & 27 & 61 & 3 & 1 & 1 & 1 & 2 & 3 & 4 & 5 & 27 & 122 & 9 & 4 & 5 & 167 \\
\hline
\end{tabular}




\begin{tabular}{|c|c|c|c|c|c|c|c|c|c|c|c|c|c|c|c|c|c|c|}
\hline & $\begin{array}{lr}\text { Praja tidak } & \text { selalu } \\
\text { memperhitungkan } & \text { faktor } \\
\text { ketelitiannya } & \text { terlebih } \\
\text { dahulu } & \text { sebelum } \\
\text { melaksanakan } & \\
\text { pekerjaannya } & \\
\end{array}$ & & & & & & & & & & & & & & & & & \\
\hline 5 & $\begin{array}{l}\text { Satuan Polisi Pamong } \\
\text { Praja sudah mempunyai } \\
\text { keterampilan yang handal } \\
\text { dan berpengalaman }\end{array}$ & 33 & 29 & 58 & 4 & 2 & 0 & 5 & 4 & 3 & 2 & 1 & 145 & 232 & 12 & 4 & 0 & 393 \\
\hline 6 & $\begin{array}{l}\text { Satuan Polisi Pamong } \\
\text { Praja kurang mempunyai } \\
\text { keterampilan yang handal } \\
\text { dan berpengalaman }\end{array}$ & 34 & 31 & 54 & 7 & 1 & 0 & 1 & 2 & 3 & 4 & 5 & 31 & 108 & 21 & 4 & 0 & 164 \\
\hline 7. & $\begin{array}{l}\text { Satuan Polisi Pamong } \\
\text { Praja selalu berhasil } \\
\text { melaksanakan tugas dan } \\
\text { terarah kepada kelompok } \\
\text { sasarannya }\end{array}$ & 35 & 18 & 55 & 14 & 6 & 0 & 5 & 4 & 3 & 2 & 1 & 90 & 220 & 42 & 12 & 0 & 364 \\
\hline 8. & $\begin{array}{lrr}\text { Satuan Polisi } & \text { Pamong } \\
\text { Praja kurang } & \text { berhasil } \\
\text { didalam melaksanakan } & \text { melom } \\
\text { tugas dan } & \text { kelompok } \\
\text { sasarannya } & \\
\end{array}$ & 36 & 14 & 62 & 11 & 5 & 1 & 1 & 2 & 3 & 4 & 5 & 14 & 124 & 33 & 20 & 5 & 196 \\
\hline & & & & & & & & & & & & & & \multicolumn{4}{|c|}{ Jumlah } & 2248 \\
\hline
\end{tabular}

\section{Sumber: Data Hasil Penelitian,2010}

Tabel 4.16 Total Skor Dimensi Kualitas Kerja, menunjukkan perkalian antara jumlah jawaban responden untuk masing-masing item pernyataan yang memiliki alternatif jawaban Sangat Setuju (SS), Setuju (S), Netral (N), Tidak Setuju (TS), dan Sangat Tidak Setuju (STS) dengan nilai alternatif jawaban mengacu pada skor jawaban untuk item pernyataan yang positif dan negatif. Pernyataan pada prinsip ini menggunakan alternatif jawaban yang positif dan negatif. Pada kolom akhir diperoleh jumlah perkalian antara jumlah responden yang menjawab masing-masing alternatif jawaban dengan skor item pernyataan, dan penjumlahannya menghasilkan total skor kecenderungan jawaban untuk Dimensi Kualitas Kerja, yaitu sebesar $\Sigma \mathbf{f i} . \mathbf{X i}=2248$.

Perhitungan Persentase jawaban responden dapat dilihat pada tabel 4.17 Disribusi Frekuensi Dimensi Kualitas Kerja, sebagai berikut : 
Tabel 4.17

Distribusi Frekuensi Dimensi Kualitas Kerja

\begin{tabular}{|c|c|c|c|c|c|c|c|c|c|c|c|c|}
\hline \multirow{2}{*}{ No. } & \multirow{2}{*}{ Pernyataan } & \multirow{2}{*}{ Kode } & \multicolumn{5}{|c|}{ Alternatif Jawaban } & \multirow{2}{*}{\multicolumn{5}{|c|}{ Presentase (\%) }} \\
\hline & & & SS & $\mathrm{S}$ & $\mathrm{N}$ & TS & STS & & & & & \\
\hline 1. & $\begin{array}{l}\text { Satuan Polisi Pamong } \\
\text { Praja mempunyai } \\
\text { ketepatan didalam } \\
\text { melaksanakan tugas } \\
\text { kepada kelompok } \\
\text { sasaranya } \\
\end{array}$ & 29 & 23 & 58 & 4 & 6 & 2 & 24.7 & 62.4 & 4.3 & 6.5 & 2.2 \\
\hline 2. & $\begin{array}{l}\text { Satuan Polisi Pamong } \\
\text { Praja kurang mempunyai } \\
\text { ketepatan kepada } \\
\text { kelompok sasaran didalam } \\
\text { melaksanakan tugasnya }\end{array}$ & 30 & 26 & 57 & 9 & 4 & 1 & 28.0 & 61.3 & 9.7 & 4.3 & 1.1 \\
\hline 3. & $\begin{array}{l}\text { Satuan Polisi Pamong } \\
\text { Praja selalu } \\
\text { memperhitungkan faktor } \\
\text { ketelitiannya terlebih } \\
\text { dahulu sebelum } \\
\text { melaksanakan } \\
\text { pekerjaannya }\end{array}$ & 31 & 35 & 54 & 4 & 0 & 0 & 37.6 & 58.1 & 4.3 & 0.0 & 0.0 \\
\hline 4. & $\begin{array}{l}\text { Satuan Polisi Pamong } \\
\text { Praja tidak selalu } \\
\text { memperhitungkan faktor } \\
\text { ketelitiannya terlebih } \\
\text { dahulu sebelum } \\
\text { melaksanakan } \\
\text { pekerjaannya }\end{array}$ & 32 & 27 & 61 & 3 & 1 & 1 & 29.0 & 65.6 & 3.2 & 1.1 & 1.1 \\
\hline 5. & $\begin{array}{l}\text { Satuan Polisi Pamong } \\
\text { Praja sudah mempunyai } \\
\text { keterampilan yang handal } \\
\text { dan berpengalaman }\end{array}$ & 33 & 29 & 58 & 4 & 2 & 0 & 31.2 & 62.4 & 4.3 & 2.2 & 0.0 \\
\hline 6. & $\begin{array}{l}\text { Satuan Polisi Pamong } \\
\text { Praja kurang mempunyai } \\
\text { keterampilan yang handal } \\
\text { dan berpengalaman }\end{array}$ & 34 & 31 & 54 & 7 & 1 & 0 & 33.3 & 58.1 & 7.5 & 1.1 & 0.0 \\
\hline 7. & $\begin{array}{l}\text { Satuan Polisi Pamong } \\
\text { Praja selalu berhasil } \\
\text { melaksanakan tugas dan } \\
\text { terarah kepada kelompok } \\
\text { sasarannya }\end{array}$ & 35 & 18 & 55 & 14 & 6 & 0 & 19.4 & 59.1 & 15.1 & 6.5 & 0.0 \\
\hline 8. & $\begin{array}{l}\text { Satuan Polisi Pamong } \\
\text { Praja kurang berhasil } \\
\text { didalam melaksanakan } \\
\text { tugas dan kelompok } \\
\text { sasarannya }\end{array}$ & 36 & 14 & 62 & 11 & 5 & 1 & 15.1 & 66.7 & 11.8 & 5.4 & 1.1 \\
\hline
\end{tabular}

\section{Sumber: Data Hasil Penelitian,2010}

Berdasarkan tabel 4.17, menggambarkan bahwa presentase jawaban responden menunjukan bahwa dimensi kualitas kerja telah relatif baik, hali ini ditunjukan dengan tugas-tugas yang secara umum sudah bisa diselesaikan oleh pelaksana walaupun terkadang belum benar-benar sesuai dengan pelaksanaan kebijakannya. 
Rentang nilai diperoleh dari perkalian antara jumlah responden dengan delapan item pernyataan, dan selanjutnya dikalikan dengan skor alternatif jawaban, sehingga diperoleh skor rentang nilai jawaban maksimum $\left(R_{\text {maks }}=3720\right)$, dan nilai jawaban minimum $\left(\mathrm{R}_{\min }=744\right)$ sebagai berikut :

93 responden $\mathrm{x} 8$ item $\times 5=3720$

93 responden $x 8$ item x $4=2976$

93 responden $\times 8$ item $\times 3=2232$

93 responden $\mathrm{x} 8$ item $\mathrm{x} 2=1488$

93 responden $\times 8$ item $\times 1=744$

Hasil perhitungan tersebut memberikan gambaran bahwa dimensi kualitas kerja mempunyai Rentang nilai pada hasil penelitian ini yang berdasarkan skor minimum dan skor maksimum jawaban responden yang telah dijelaskan di atas, dan perhitungan pada tabel yang menghasilkan total nilai skor $\Sigma \mathbf{f i}$. $\mathbf{X i}=2248$ digambarkan pada kontinum sebagai berikut:

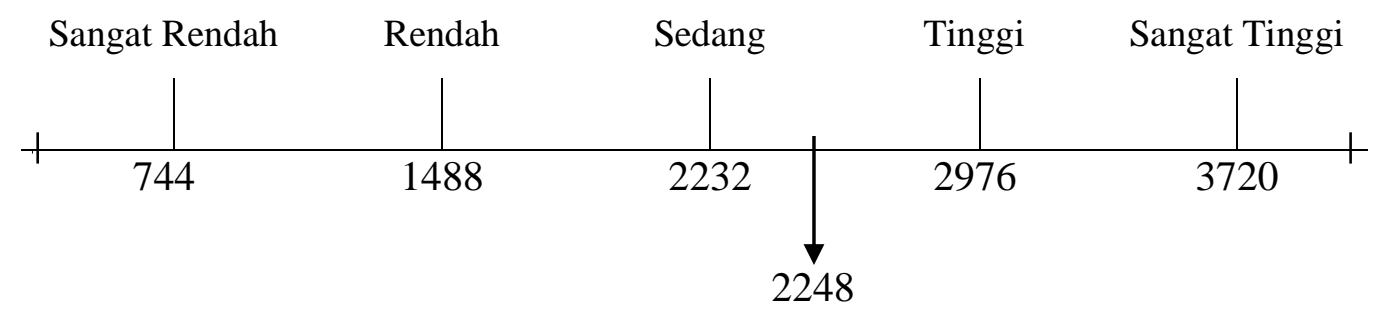

Gambar 4.7

Kontinum Faktor dimensi kualitas kerja

Mengacu pada gambar 4.6 kontinum dimensi kualitas kerja bahwa hasil perhitungan di atas yang tertera pada tabel 4.16 total skor dimensi kualitas kerja 
menunjukan pada umumnya responden mengganggap penting dimensi kualitas kerja, dengan hasil skor jawaban responden $\Sigma \mathbf{f i} . \mathbf{X i}=2248$, dimana hasil tersebut berada pada tahapan antara kontinum sedang menuju ke tinggi

\subsubsection{Dimensi Kuantitas Kerja}

Dimensi kuantitas kerja meliputi dua indikator, yaitu pekerjaan oreintasi tujuan, tugas khusus yang terdiri dari empat item pernyataan positif dan negatif untuk sembilan puluh tiga responden. Untuk mengetahui hasil tanggapan responden dimensi kuantitas kerja dapat dilihat tabel 4.18 total skor dimensi kuantitas kerja, sebagai berikut :

Tabel 4.18

Total Skor Dimensi Kuantitas Kerja

\begin{tabular}{|c|c|c|c|c|c|c|c|c|c|c|c|c|c|c|c|c|c|c|}
\hline \multirow{3}{*}{$\begin{array}{c}\text { No } \\
1\end{array}$} & \multirow{3}{*}{ 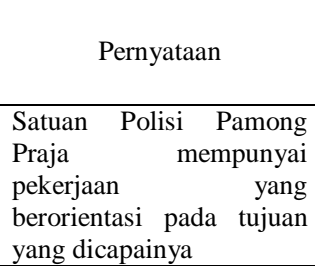 } & \multirow{3}{*}{$\begin{array}{c}\text { Kode } \\
37\end{array}$} & \multicolumn{5}{|c|}{$\mathrm{Fi}$} & \multirow{2}{*}{\multicolumn{5}{|c|}{$\mathrm{Xi}$}} & \multirow{2}{*}{\multicolumn{5}{|c|}{ FixXi }} & \multirow{3}{*}{$\begin{array}{r}\text { Fi.Xi } \\
394\end{array}$} \\
\hline & & & \multirow{2}{*}{$\begin{array}{l}\text { SS } \\
25\end{array}$} & \multirow{2}{*}{$\begin{array}{c}S \\
66\end{array}$} & \multirow{2}{*}{ 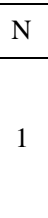 } & \multirow{2}{*}{$\begin{array}{c}\mathrm{TS} \\
1\end{array}$} & \multirow{2}{*}{$\begin{array}{c}\text { STS } \\
0\end{array}$} & & & & & & & & & & & \\
\hline & & & & & & & & 5 & 4 & 3 & 2 & 1 & 125 & 264 & 3 & 2 & 0 & \\
\hline 2 & $\begin{array}{lr}\text { Satuan Polisi } & \text { Pamong } \\
\text { Praja tidak mempunyai } \\
\text { Pekerjaan }\end{array}$ & 38 & 18 & 59 & 9 & 6 & 1 & 1 & 2 & 3 & 4 & 5 & 18 & 118 & 27 & 24 & 5 & 192 \\
\hline 3 & $\begin{array}{lrr}\text { Satuan } & \text { Polisi } & \text { Pamong } \\
\text { Praja selalu diberikan } \\
\text { tugas khusus } & \text { untuk } \\
\text { melaksanakan } & \text { fungsi, } \\
\text { tugas } & \text { dan } \\
\text { tanggungjawabnya } & \\
\end{array}$ & 39 & 22 & 63 & 7 & 1 & 0 & 5 & 4 & 3 & 2 & 1 & 110 & 252 & 21 & 2 & 0 & 385 \\
\hline 4 & $\begin{array}{lrr}\text { Satuan Polisi } & \text { Pamong } \\
\text { Praja jarang } & \text { sekali } \\
\text { diberikan tugas khusus } \\
\text { untuk melaksanakan } \\
\text { fungsi, tugas dan } \\
\text { tanggungjawabnya }\end{array}$ & 40 & 14 & 56 & 16 & 7 & 0 & 1 & 2 & 3 & 4 & 5 & 14 & 112 & 48 & 28 & 0 & 202 \\
\hline & & & & & & & & & & & & & & & & & & 1173 \\
\hline
\end{tabular}

\section{Sumber: Data Hasil Penelitian,2010}

Tabel 4.18 Total Skor Dimensi Kuantitas Kerja, menunjukkan perkalian antara jumlah jawaban responden untuk masing-masing item pernyataan yang 
memiliki alternatif jawaban Sangat Setuju (SS), Setuju (S), Netral (N), Tidak Setuju (TS), dan Sangat Tidak Setuju (STS) dengan nilai alternatif jawaban mengacu pada skor jawaban untuk item pernyataan yang positif dan negatif. Pernyataan pada prinsip ini menggunakan alternatif jawaban yang positif dan negatif. Pada kolom akhir diperoleh jumlah perkalian antara jumlah responden yang menjawab masing-masing alternatif jawaban dengan skor item pernyataan, dan penjumlahannya menghasilkan total skor kecenderungan jawaban untuk Dimensi Kuantitas Kerja, yaitu sebesar $\Sigma \mathbf{f i} . \mathbf{X i}=1173$.

Perhitungan Persentase jawaban responden dapat dilihat pada tabel 4.19 Disribusi Frekuensi Dimensi Kuantitas Kerja, sebagai berikut :

Tabel 4.19

Distribusi Frekuensi Dimensi Kuantitas Kerja

\begin{tabular}{|c|c|c|c|c|c|c|c|c|c|c|c|c|}
\hline \multirow{2}{*}{ No. } & \multirow{2}{*}{ Pernyataan } & \multirow{2}{*}{ Kode } & \multicolumn{5}{|c|}{ Alternatif Jawaban } & \multirow{2}{*}{\multicolumn{5}{|c|}{ Presentase (\%) }} \\
\hline & & & SS & $\mathrm{S}$ & $\mathrm{N}$ & TS & STS & & & & & \\
\hline 1. & $\begin{array}{lr}\text { Satuan Polisi } & \text { Pamong } \\
\text { Praja } & \text { mempunyai } \\
\text { pekerjaan } & \text { yang } \\
\text { berorientasi pada tujuan } \\
\text { yang dicapainya }\end{array}$ & 37 & 25 & 66 & 1 & 1 & 0 & 26.9 & 71.0 & 1.1 & 1.1 & 0.0 \\
\hline 2. & $\begin{array}{lr}\text { Satuan Polisi } & \text { Pamong } \\
\text { Praja tidak mempunyai } \\
\text { Pekerjaan } & \text { yang } \\
\text { berorientasi pada tujuan }\end{array}$ & 38 & 18 & 59 & 9 & 6 & 1 & 19.4 & 63.4 & 9.7 & 6.5 & 1.1 \\
\hline 3. & $\begin{array}{lrr}\text { Satuan } & \text { Polisi } & \text { Pamong } \\
\text { Praja selalu diberikan } \\
\text { tugas khusus } & \text { untuk } \\
\text { melaksanakan } & \text { fungsi, } \\
\text { tugas } & \text { dan } \\
\text { tanggungjawabnya } & \end{array}$ & 39 & 22 & 63 & 7 & 1 & 0 & 23.7 & 67.7 & 7.5 & 1.1 & 0.0 \\
\hline 4. & $\begin{array}{l}\text { Satuan Polisi } \text { Pamong } \\
\text { Praja jarang r sekali } \\
\text { diberikan tugas khusus } \\
\text { untuk melaksanakan } \\
\text { fungsi, tugas dan } \\
\text { tanggungjawabnya }\end{array}$ & 40 & 14 & 56 & 16 & 7 & 0 & 15.1 & 60.2 & 17.2 & 7.5 & 0.0 \\
\hline
\end{tabular}

\section{Sumber: Data Hasil Penelitian,2010}

Berdasarkan tabel 4.19, menggambarkan bahwa presentase jawaban responden menunjukan menyetujui beberapa pernyataan yang diajukan peneliti, 
berarti dimensi kuantitas kerja dalam prose pelaksanaannya sudah sesuai dengan orentasi tujuannya dan sudah sepenuhnya melaksanakan tugas sesuai dengan tanggung jawabnya. Namun masih ada beberapa pegawai yang belum melaksanakan pekerjaannya dengan sebaik mungkin yang tidak sesuai dengan pencapain tujuannya dalam pelaksanaan kebijakan.

Rentang nilai diperoleh dari perkalian antara jumlah responden dengan delapan item pernyataan, dan selanjutnya dikalikan dengan skor alternatif jawaban, sehingga diperoleh skor rentang nilai jawaban maksimum $\left(\mathrm{R}_{\text {maks }}=1860\right)$, dan nilai jawaban minimum $\left(\mathrm{R}_{\min }=372\right)$ sebagai berikut :

93 responden $\mathrm{x} 4$ item $\mathrm{x} 5=1860$

93 responden $\mathrm{x} 4$ item $\mathrm{x} 4=1488$

93 responden $\times 4$ item $\times 3=1116$

93 responden $\mathrm{x} 4$ item $\times 2=744$

93 responden $\mathrm{x} 4$ item $\mathrm{x} 1=372$

Hasil perhitungan tersebut memberikan gambaran bahwa Dimensi kuantitas Kerja mempunyai Rentang nilai pada hasil penelitian ini yang berdasarkan skor minimum dan skor maksimum jawaban responden yang telah dijelaskan di atas, dan perhitungan pada tabel yang menghasilkan total nilai skor $\Sigma$ fi. $\mathbf{X i}=1173$ digambarkan pada kontinum sebagai berikut: 


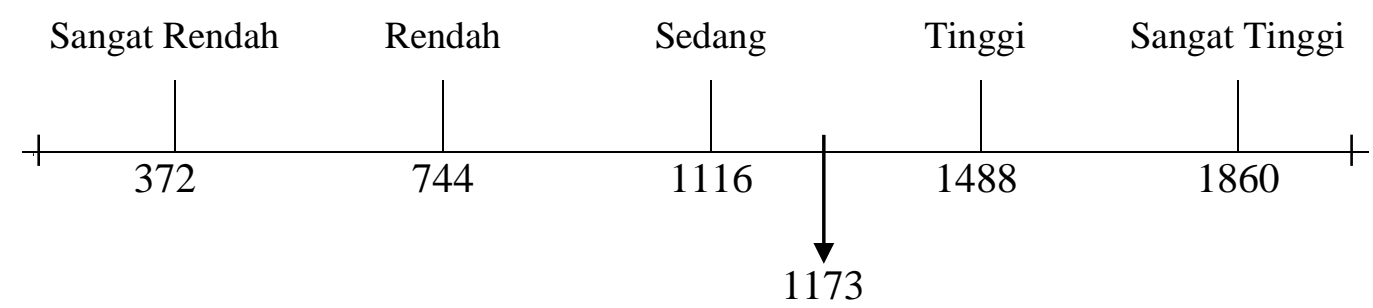

Gambar 4.8

Kontinum Dimensi Kuantitas Kerja

Mengacu pada gambar 4.8 kontinum dimensi kuantitas kerja bahwa hasil perhitungan di atas yang tertera pada tabel 4.18 total skor dimensi kuantitas kerja menunjukan pada umumnya responden mengganggap penting dimensi kuantitas kerja, dengan hasil skor jawaban responden $\Sigma \mathbf{f i} . \mathbf{X i}=1173$, dimana hasil tersebut berada pada tahapan antara kontinum sedang menuju ke tinggi.

\subsubsection{Dimensi Keandalan}

Dimensi keandalan meliputi lima indikator, yaitu intruksi, kemampuan, inisiatif, kehati-hatian, kerajinan yang teridiri dari sepuluh item pernyataan positif dan negatif untuk sembilan puluh tiga responden. Untuk mengetahui hasil tanggapan responden dimensi keandalan dapat dilihat tabel 4.20 total skor dimensi keandalan, sebagai berikut :

Tabel 4.20

Total Skor Dimensi Keandalan

\begin{tabular}{|c|c|c|c|c|c|c|c|c|c|c|c|c|c|c|c|c|c|c|}
\hline \multirow{2}{*}{ No } & \multirow{2}{*}{ Pernyataan } & \multirow{2}{*}{ Kode } & \multicolumn{5}{|c|}{$\mathrm{Fi}$} & \multirow{2}{*}{\multicolumn{5}{|c|}{$\mathrm{Xi}$}} & \multirow{2}{*}{\multicolumn{5}{|c|}{ FixXi }} & \multirow{2}{*}{ Fi.Xi } \\
\hline & & & SS & S & $\mathrm{N}$ & TS & STS & & & & & & & & & & & \\
\hline 1 & $\begin{array}{lll}\text { Setiap ada } & \text { intruksi dari } \\
\text { pimpinan } & \text { Satuan } & \text { Polisi } \\
\text { Pamong } & \text { Praja } & \text { selalu } \\
\text { langsung } & \text { melaksanakan } \\
\text { tugas } & & \text { dan }\end{array}$ & 41 & 32 & 55 & 5 & 1 & 0 & 5 & 4 & 3 & 2 & 1 & 160 & 220 & 15 & 2 & 0 & 397 \\
\hline
\end{tabular}




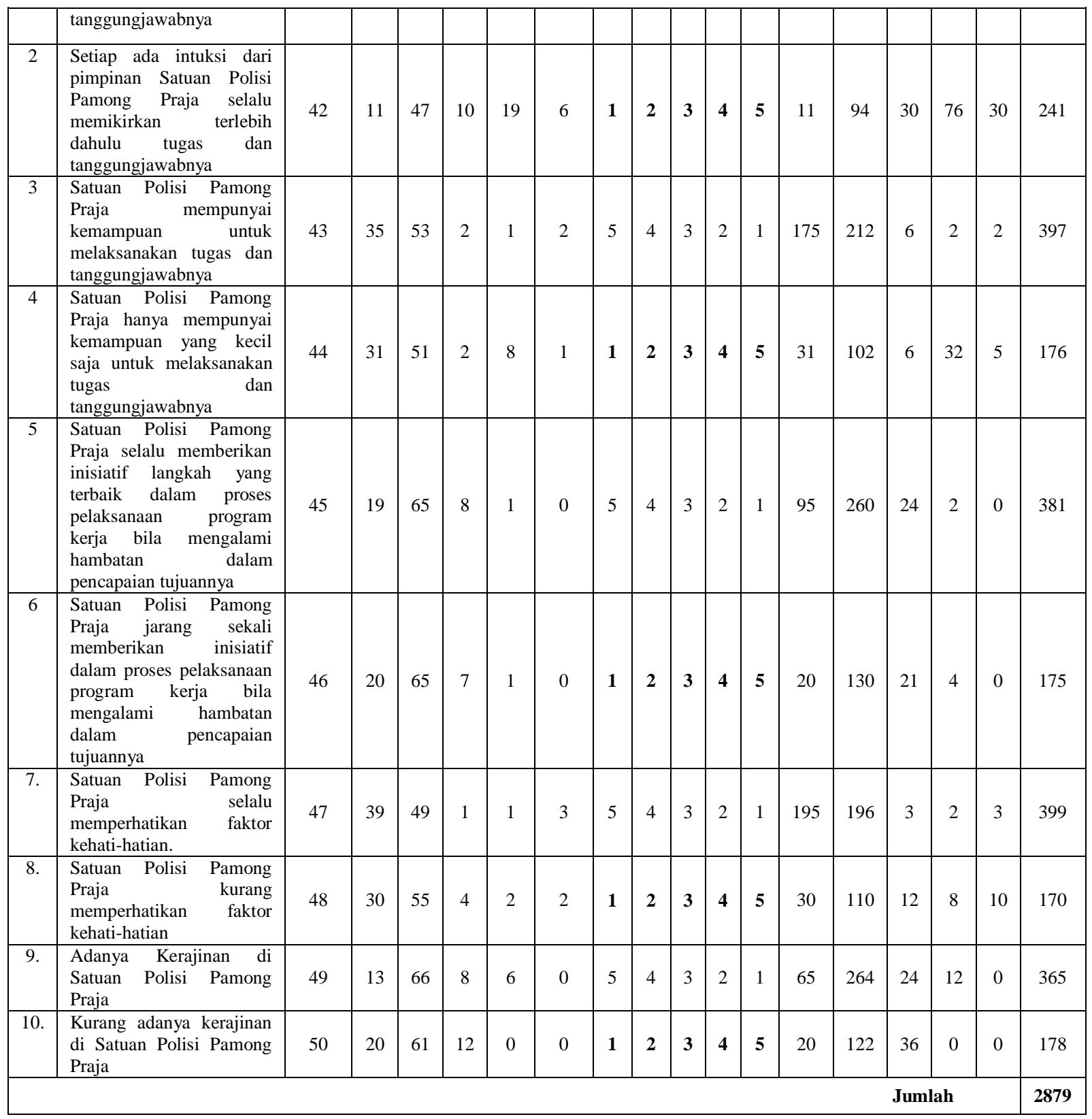

\section{Sumber: Data Hasil Penelitian,2010}

Tabel 4.20 Total Skor Dimensi Keandalan, menunjukkan perkalian antara jumlah jawaban responden untuk masing-masing item pernyataan yang memiliki alternatif jawaban Sangat Setuju (SS), Setuju (S), Netral (N), Tidak Setuju (TS), dan Sangat Tidak Setuju (STS) dengan nilai alternatif jawaban mengacu pada skor 
jawaban untuk item pernyataan yang positif dan negatif. Pernyataan pada prinsip ini menggunakan alternatif jawaban yang positif dan negatif. Pada kolom akhir diperoleh jumlah perkalian antara jumlah responden yang menjawab masingmasing alternatif jawaban dengan skor item pernyataan, dan penjumlahannya menghasilkan total skor kecenderungan jawaban untuk Dimensi Keandalan, yaitu sebesar $\Sigma$ fi. $\mathbf{X i}=2879$.

Perhitungan Persentase jawaban responden dapat dilihat pada tabel 4.21 Disribusi Frekuensi Dimensi Keandalan, sebagai berikut :

Tabel 4.21

Distribusi Frekuensi Dimensi Keandalan

\begin{tabular}{|c|c|c|c|c|c|c|c|c|c|c|c|c|}
\hline \multirow{2}{*}{ No. } & \multirow{2}{*}{ Pernyataan } & \multirow{2}{*}{ Kode } & \multicolumn{5}{|c|}{ Alternatif Jawaban } & \multirow{2}{*}{\multicolumn{5}{|c|}{ Presentase (\%) }} \\
\hline & & & SS & $\mathrm{S}$ & $\mathrm{N}$ & TS & STS & & & & & \\
\hline 1. & \begin{tabular}{llr} 
Setiap ada & intruksi & dari \\
pimpinan & Satuan & Polisi \\
Pamong & Praja & selalu \\
langsung & melaksanakan \\
tugas & \multicolumn{2}{c}{ dan } \\
tanggungjawabnya
\end{tabular} & 41 & 32 & 55 & 5 & 1 & 0 & 34.4 & 59.1 & 5.4 & 1.1 & 0.0 \\
\hline 2. & $\begin{array}{lr}\text { Setiap ada intuksi dari } \\
\text { pimpinan Satuan Polisi } \\
\text { Pamong Praja } & \text { selalu } \\
\text { memikirkan } & \text { terlebih } \\
\text { dahulu tugas } & \text { dan } \\
\text { tanggungjawabnya } & \\
\end{array}$ & 42 & 11 & 47 & 10 & 19 & 6 & 11.8 & 50.5 & 10.8 & 20.4 & 6.5 \\
\hline 3. & $\begin{array}{l}\text { Satuan Polisi Pamong } \\
\text { Praja mempunyai } \\
\text { kemampuan untuk } \\
\text { melaksanakan tugas dan } \\
\text { tanggungjawabnya }\end{array}$ & 43 & 35 & 53 & 2 & 1 & 2 & 37.6 & 57.0 & 2.2 & 1.1 & 2.2 \\
\hline 4. & $\begin{array}{l}\text { Satuan Polisi Pamong } \\
\text { Praja hanya mempunyai } \\
\text { kemampuan yang kecil } \\
\text { saja untuk melaksanakan } \\
\text { tugas dan } \\
\text { tanggungjawabnya }\end{array}$ & 44 & 31 & 51 & 2 & 8 & 1 & 33.3 & 54.8 & 2.2 & 8.6 & 1.1 \\
\hline 5. & $\begin{array}{l}\text { Satuan Polisi Pamong } \\
\text { Praja selalu memberikan } \\
\text { inisiatif langkah yang } \\
\text { terbaik dalam proses } \\
\text { pelaksanaan program } \\
\text { kerja bila mengalami } \\
\text { hambatan dalam } \\
\text { pencapaian tujuannya }\end{array}$ & 45 & 19 & 65 & 8 & 1 & 0 & 20.4 & 69.9 & 8.6 & 1.1 & 0.0 \\
\hline 6. & $\begin{array}{lrr}\text { Satuan Polisi } & \text { Pamong } \\
\text { Praja jarang } & \text { sekali } \\
\text { memberikan } & \text { inisiatif }\end{array}$ & 46 & 20 & 65 & 7 & 1 & 0 & 21.5 & 69.9 & 7.5 & 1.1 & 0.0 \\
\hline
\end{tabular}




\begin{tabular}{|c|c|c|c|c|c|c|c|c|c|c|c|c|}
\hline & \begin{tabular}{lr}
\multicolumn{2}{l}{ dalam proses pelaksanaan } \\
program & kerja bila \\
mengalami & hambatan \\
dalam & pencapaian \\
tujuannya & \\
\end{tabular} & & & & & & & & & & & \\
\hline 7. & $\begin{array}{lr}\text { Satuan Polisi } & \text { Pamong } \\
\text { Praja } & \text { selalu } \\
\text { memperhatikan } & \text { faktor } \\
\text { kehati-hatian. } & \\
\end{array}$ & 47 & 39 & 49 & 1 & 1 & 3 & 41.9 & 52.7 & 1.1 & 1.1 & 3.2 \\
\hline 8. & $\begin{array}{lr}\begin{array}{l}\text { Satuan Polisi } \\
\text { Praja }\end{array} & \begin{array}{r}\text { Pamong } \\
\text { kurang }\end{array} \\
\text { memperhatikan } & \text { faktor } \\
\text { kehati-hatian } & \\
\end{array}$ & 48 & 30 & 55 & 4 & 2 & 2 & 32.3 & 59.1 & 4.3 & 2.2 & 2.2 \\
\hline 9. & \begin{tabular}{lcr} 
Adanya & \multicolumn{2}{c}{ Kerajinan di } \\
Satuan & Polisi Pamong \\
Praja & & \\
\end{tabular} & 49 & 13 & 66 & 8 & 6 & 0 & 14.0 & 71.0 & 8.6 & 6.5 & 0.0 \\
\hline 10. & $\begin{array}{l}\text { Kurang adanya kerajinan } \\
\text { di Satuan Polisi Pamong } \\
\text { Praja }\end{array}$ & 50 & 20 & 61 & 12 & 0 & 0 & 21.5 & 65.6 & 12.9 & 0.0 & 0.0 \\
\hline
\end{tabular}

\section{Sumber: Data Hasil Penelitian,2010}

Berdasarkan tabel 4.21, menggambarkan bahwa presentase jawaban responden memperlihatkan bahwa dimensi keandalan dalam proses pelaksanaan implementsi kebijakan sudah cukup efektif. Hal ini ditunjukan oleh beberapa pekerjaan yang diselesaikan oleh pegawai sesuai dengan bidang pekerjaanya, akan tetapi tidak hanya dalam bidang kerjanya saja melainkan mereka pun atau pegawai itu bisa menyelesaikan selain dari bidangnya pekerjaanya.

Rentang nilai diperoleh dari perkalian antara jumlah responden dengan delapan item pernyataan, dan selanjutnya dikalikan dengan skor alternatif jawaban, sehingga diperoleh skor rentang nilai jawaban maksimum $\left(R_{\text {maks }}=4650\right)$, dan nilai jawaban minimum $\left(\mathrm{R}_{\min }=930\right)$ sebagai berikut :

93 responden $\times 10$ item x $5=4650$

93 responden $\times 10$ item $\times 4=3720$

93 responden $\times 10$ item $\times 3=2790$

93 responden $\times 10$ item $\times 2=1860$

93 responden $\mathrm{x} 10$ item $\mathrm{x} 1=930$ 
Hasil perhitungan tersebut memberikan gambaran bahwa dimensi keandalan mempunyai Rentang nilai pada hasil penelitian ini yang berdasarkan skor minimum dan skor maksimum jawaban responden yang telah dijelaskan di atas, dan perhitungan pada tabel yang menghasilkan total nilai skor $\Sigma \mathbf{f i}$. $\mathbf{X i}=2879$ digambarkan pada kontinum sebagai berikut:

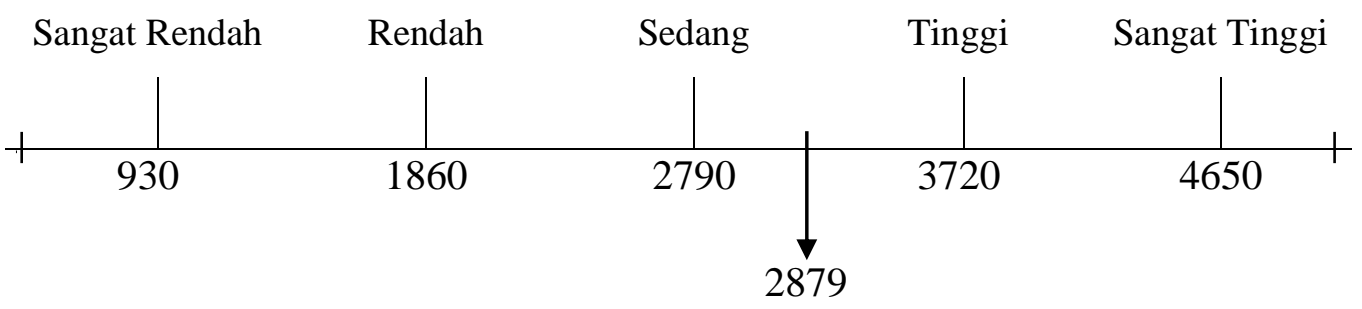

Gambar 4.9

Kontinum dimensi keandalan

Mengacu pada gambar 4.9 kontinum dimensi Keandalan bahwa hasil perhitungan di atas yang tertera pada tabel 4.20 total skor dimensi keandalan menunjukan pada umumnya responden mengganggap penting dimensi keandalan, dengan hasil skor jawaban responden $\Sigma \mathbf{f i} . \mathbf{X i}=2879$, dimana hasil tersebut berada pada tahapan antara kontinum sedang menuju ke tinggi.

\subsubsection{Dimensi Sikap}

Dimensi sikap meliputi empat indikator, yaitu sikap pada organisasi, sikap pada orang lain, sikap pada pekerjaan, sikap pada kerjasama, yang teridiri dari delapan item pernyataan positif dan negatif untuk sembilan puluh tiga responden. Untuk mengetahui hasil tanggapan responden dimensi sikap dapat dilihat tabel 4.22 total skor dimensi sikap, sebagai berikut : 
Tabel 4.22

Total Skor Dimensi Sikap

\begin{tabular}{|c|c|c|c|c|c|c|c|c|c|c|c|c|c|c|c|c|c|c|}
\hline \multirow{3}{*}{$\begin{array}{c}\text { No } \\
1\end{array}$} & \multirow{3}{*}{$\begin{array}{l}\text { Pernyataan } \\
\text { Satuan Polisi Pamong } \\
\text { Praja mempunyai sikap } \\
\text { pada organisasi secara } \\
\text { sepenuhnya }\end{array}$} & \multirow{3}{*}{$\begin{array}{c}\text { Kode } \\
51\end{array}$} & \multicolumn{5}{|c|}{$\mathrm{Fi}$} & \multirow{2}{*}{\multicolumn{5}{|c|}{$\mathrm{Xi}$}} & \multirow{2}{*}{\multicolumn{5}{|c|}{ FixXi }} & \multirow{3}{*}{$\begin{array}{r}\text { Fi.Xi } \\
350\end{array}$} \\
\hline & & & \multirow{2}{*}{$\begin{array}{c}\text { SS } \\
5\end{array}$} & \multirow{2}{*}{$\begin{array}{l}S \\
61\end{array}$} & \multirow{2}{*}{$\begin{array}{l}\mathrm{N} \\
27\end{array}$} & \multirow{2}{*}{$\begin{array}{c}\mathrm{TS} \\
0\end{array}$} & \multirow{2}{*}{$\begin{array}{c}\text { STS } \\
0\end{array}$} & & & & & & & & & & & \\
\hline & & & & & & & & 5 & 4 & 3 & 2 & 1 & 25 & 244 & 81 & 0 & 0 & \\
\hline 2 & $\begin{array}{l}\text { Satuan Polisi Pamong } \\
\text { Praja kurang mempunyai } \\
\text { sikap pada organisasi } \\
\text { secara sepenuhnya }\end{array}$ & 52 & 7 & 52 & 28 & 4 & 2 & 1 & 2 & 3 & 4 & 5 & 7 & 104 & 84 & 16 & 10 & 221 \\
\hline 3 & $\begin{array}{l}\text { Satuan Polisi Pamong } \\
\text { Praja } \\
\text { memperhatikan etika dan } \\
\text { norma sikap pada orang } \\
\text { lain }\end{array}$ & 53 & 36 & 49 & 4 & 4 & 0 & 5 & 4 & 3 & 2 & 1 & 180 & 196 & 12 & 8 & 0 & 396 \\
\hline 4 & $\begin{array}{l}\text { Satuan Polisi Pamong } \\
\text { Praja selalu menghiraukan } \\
\text { etika dan norma sikap } \\
\text { pada orang lain }\end{array}$ & 54 & 30 & 48 & 7 & 2 & 6 & 1 & 2 & 3 & 4 & 5 & 30 & 96 & 21 & 8 & 30 & 185 \\
\hline 5 & $\begin{array}{l}\text { Satuan Polisi Pamong } \\
\text { Praja mempunyai loyalitas } \\
\text { yang tinggi sikap pada } \\
\text { pekerjaanya }\end{array}$ & 55 & 32 & 59 & 2 & 0 & 0 & 5 & 4 & 3 & 2 & 1 & 160 & 236 & 6 & 0 & 0 & 402 \\
\hline 6 & $\begin{array}{l}\text { Satuan Polisi } \begin{array}{l}\text { Pamong } \\
\text { Praja kurang } \\
\text { sikap pada pekerjaanya }\end{array} \\
\end{array}$ & 56 & 43 & 45 & 3 & 2 & 0 & 1 & 2 & 3 & 4 & 5 & 43 & 90 & 9 & 8 & 0 & 150 \\
\hline 7. & $\begin{array}{l}\text { Satuan Polisi Pamong } \\
\text { Praja masih adanya sikap } \\
\text { pada kerjasama yang erat } \\
\text { dan baik }\end{array}$ & 57 & 18 & 63 & 12 & 0 & 0 & 5 & 4 & 3 & 2 & 1 & 90 & 252 & 36 & 0 & 0 & 378 \\
\hline 8. & $\begin{array}{l}\text { Satuan Polisi Pamong } \\
\text { Praja kurang adanya sikap } \\
\text { pada kerjasama yang erat } \\
\text { dan baik }\end{array}$ & 58 & 27 & 53 & 6 & 5 & 2 & 1 & 2 & 3 & 4 & 5 & 27 & 106 & 18 & 20 & 10 & 181 \\
\hline & & & & & & & & & & & & & & & Ju & & & 2263 \\
\hline
\end{tabular}

\section{Sumber: Data Hasil Penelitian,2010}

Tabel 4.22 Total Skor Dimensi sikap, menunjukkan perkalian antara jumlah jawaban responden untuk masing-masing item pernyataan yang memiliki alternatif jawaban Sangat Setuju (SS), Setuju (S), Netral (N), Tidak Setuju (TS), dan Sangat Tidak Setuju (STS) dengan nilai alternatif jawaban mengacu pada skor jawaban untuk item pernyataan yang positif dan negatif. Pernyataan pada prinsip ini menggunakan alternatif jawaban yang positif dan negatif. Pada kolom akhir 
diperoleh jumlah perkalian antara jumlah responden yang menjawab masingmasing alternatif jawaban dengan skor item pernyataan, dan penjumlahannya menghasilkan total skor kecenderungan jawaban untuk Dimensi Sikap, yaitu sebesar $\Sigma$ fi. $\mathbf{X i}=2263$.

Perhitungan Persentase jawaban responden dapat dilihat pada tabel 4.23 Disribusi Frekuensi Dimensi Sikap, sebagai berikut :

Tabel 4.23

Distribusi Frekuensi Dimensi Sikap

\begin{tabular}{|c|c|c|c|c|c|c|c|c|c|c|c|c|}
\hline \multirow{2}{*}{ No. } & \multirow{2}{*}{ Pernyataan } & \multirow{2}{*}{ Kode } & \multicolumn{5}{|c|}{ Alternatif Jawaban } & \multirow{2}{*}{\multicolumn{5}{|c|}{ Presentase (\%) }} \\
\hline & & & SS & $\mathrm{S}$ & $\mathrm{N}$ & TS & STS & & & & & \\
\hline 1. & $\begin{array}{l}\text { Satuan Polisi Pamong } \\
\text { Praja mempunyai sikap } \\
\text { pada organisasi secara } \\
\text { sepenuhnya }\end{array}$ & 51 & 5 & 61 & 27 & 0 & 0 & 5.4 & 65.6 & 29.0 & 0.0 & 0.0 \\
\hline 2. & $\begin{array}{l}\text { Satuan Polisi Pamong } \\
\text { Praja kurang mempunyai } \\
\text { sikap pada organisasi } \\
\text { secara sepenuhnya }\end{array}$ & 52 & 7 & 52 & 28 & 4 & 2 & 7.5 & 55.9 & 30.1 & 4.3 & 2.2 \\
\hline 3. & $\begin{array}{l}\text { Satuan Polisi Pamong } \\
\text { Praja } \\
\text { memperhatikan etika dan } \\
\text { norma sikap pada orang } \\
\text { lain }\end{array}$ & 53 & 36 & 49 & 4 & 4 & 0 & 38.7 & 52.7 & 4.3 & 4.3 & 0.0 \\
\hline 4. & $\begin{array}{l}\text { Satuan Polisi Pamong } \\
\text { Praja selalu menghiraukan } \\
\text { etika dan norma sikap } \\
\text { pada orang lain }\end{array}$ & 54 & 30 & 48 & 7 & 2 & 6 & 32.3 & 51.6 & 7.5 & 2.2 & 6.5 \\
\hline 5. & $\begin{array}{l}\text { Satuan Polisi Pamong } \\
\text { Praja mempunyai loyalitas } \\
\text { yang tinggi sikap pada } \\
\text { pekerjaanya }\end{array}$ & 55 & 32 & 59 & 2 & 0 & 0 & 34.4 & 63.4 & 2.2 & 0.0 & 0.0 \\
\hline 6. & $\begin{array}{l}\text { Satuan Polisi Pamong } \\
\text { Praja kurang loyalitas } \\
\text { sikap pada pekerjaanya }\end{array}$ & 56 & 43 & 45 & 3 & 2 & 0 & 46.2 & 48.4 & 3.2 & 2.2 & 0.0 \\
\hline 7. & $\begin{array}{l}\text { Satuan Polisi Pamong } \\
\text { Praja masih adanya sikap } \\
\text { pada kerjasama yang erat } \\
\text { dan baik }\end{array}$ & 57 & 18 & 63 & 12 & 0 & 0 & 19.4 & 67.7 & 12.9 & 0.0 & 0.0 \\
\hline 8. & $\begin{array}{l}\text { Satuan Polisi Pamong } \\
\text { Praja kurang adanya sikap } \\
\text { pada kerjasama yang erat } \\
\text { dan baik }\end{array}$ & 58 & 27 & 53 & 6 & 5 & 2 & 29.0 & 57.0 & 6.5 & 5.4 & 2.2 \\
\hline
\end{tabular}

\section{Sumber: Data Hasil Penelitian,2010}

Berdasarkan tabel 4.23, menggambarkan bahwa presentase jawaban responden menunjukan bahwa dimensi sikap di dalam proses pelaksanaannya 
belum menyadari pentingnya loualitas dalam organisasi, sikap saling menghormati belum menjadi suatu perilaku yang mendukung peningkatan kinerja pegawai, kerja sama sesama pegawai belum efektif. Hal ini disebabkan karena terkadang masih ada beberapa pegawai yang mementingkan dirinya sendiri dalam menajalankan tugasnya sehingga kerjsama yang terjalin belum sepenuhnya efektif. Selain itu hasil dari responden ternyata masih banyak yang menjawab pernyataanya netral, berarti pernyataan yang diajukan oleh peneliti masih terdapat kurangya loyalitas terhadap pekerjaanya.

Rentang nilai diperoleh dari perkalian antara jumlah responden dengan delapan item pernyataan, dan selanjutnya dikalikan dengan skor alternatif jawaban, sehingga diperoleh skor rentang nilai jawaban maksimum $\left(R_{\text {maks }}=3720\right)$, dan nilai jawaban minimum $\left(\mathrm{R}_{\min }=744\right)$ sebagai berikut :

93 responden $\times 8$ item $\times 5=3720$

93 responden x 8 item x $4=2976$

93 responden $\times 8$ item $\times 3=2232$

93 responden $\times 8$ item $\times 2=1488$

93 responden $\times 8$ item $\times 1=744$

Hasil perhitungan tersebut memberikan gambaran bahwa dimensi Sikap mempunyai Rentang nilai pada hasil penelitian ini yang berdasarkan skor minimum dan skor maksimum jawaban responden yang telah dijelaskan di atas, dan perhitungan pada tabel yang menghasilkan total nilai skor $\Sigma$ fi. $\mathbf{X i}=2263$ digambarkan pada kontinum sebagai berikut: 


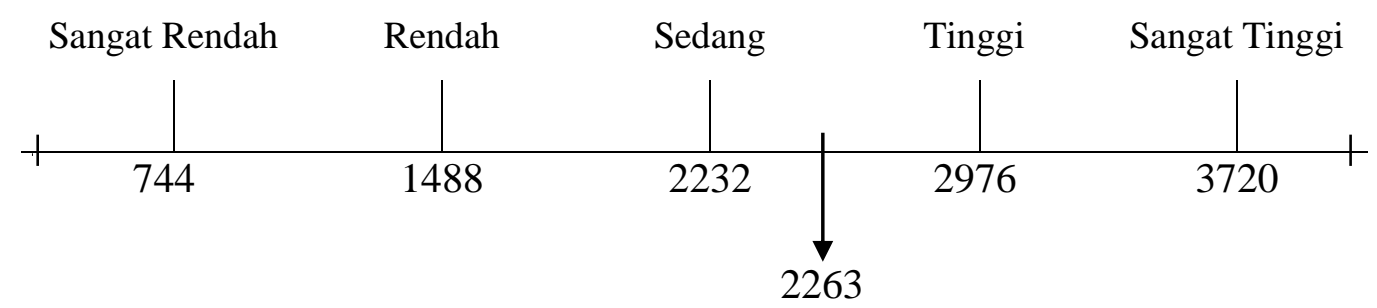

Gambar 4.10

Kontinum Dimensi Sikap

Mengacu pada gambar 4.10 kontinum dimensi sikap, bahwa hasil perhitungan di atas yang tertera pada tabel 4.22 total skor dimensi sikap menunjukan pada umumnya responden mengganggap penting dimensi sikap, dengan hasil skor jawaban responden $\Sigma \mathbf{f i} . \mathbf{X i}=2263$, dimana hasil tersebut berada pada tahapan antara kontinum sedang menuju ke tinggi.

\subsection{Pengujian Hipotesis Hasil Penelitian}

\subsubsection{Struktur Variabel X ke Y}

Struktur variabel $\mathrm{X}$ ke Y diuji berapa besar pengaruh variabel implementsi kebijakan terhadap kinerja pegawai. Metode analisis yang di gunakan adalah Path Analysis. Adapun hasil Path Analysis dijelaskan sebagai berikut:

Tabel 4.24

\section{Koefisien Korelasi Multipel}

\begin{tabular}{|c|c|c|c|c|c|}
\hline \multicolumn{6}{|c|}{ Model Summary ${ }^{b}$} \\
\hline Model & $\mathrm{R}$ & R Square & $\begin{array}{l}\text { Adjusted R } \\
\text { Square }\end{array}$ & $\begin{array}{c}\text { Std. Error of the } \\
\text { Estimate }\end{array}$ & Durbin-Watson \\
\hline 1 & $.843^{a}$ & .712 & .714 & 2.649 & 1.936 \\
\hline
\end{tabular}

a. Predictors: (Constant), $\mathrm{X}$

b. Dependent Variable: $Y$ 
Tabel 4.24 menunjukkan nilai koefisien determinasi $\left(\mathrm{R}^{2}\right)$ sebesar 0,712 berarti bahwa variabilitas kinerja pegawai dapat diterangkan oleh variabel bebas dalam hal ini implementasi kebijakan, yang juga dapat diartikan bahwa terdapat pengaruh implementasi kebijakan terhadap kinerja pegawai sebesar koefisien determinasi $\left(\mathrm{R}^{2}=71,2 \%\right)$ atau $71,2 \%$ ini juga dapat diartikan bahwa pengaruh variabel-variabel di luar model yaitu sebesar $\rho_{\mathrm{y} \varepsilon}=1-\mathrm{R}^{2}=0,288$ (error). Besarnya koefisien jalur untuk masing-masing variabel adalah sebagai berikut :

Tabel 4.25

Nilai-nilai Standardized Coefficients untuk Koefisien Jalur

\begin{tabular}{|c|c|c|c|c|c|c|}
\hline \multicolumn{7}{|c|}{ Coefficients $^{a}$} \\
\hline \multirow{2}{*}{\multicolumn{2}{|c|}{ Model }} & \multicolumn{2}{|c|}{ Unstandardized Coefficients } & $\begin{array}{l}\text { Standardized } \\
\text { Coefficients }\end{array}$ & \multirow[b]{2}{*}{$\mathrm{t}$} & \multirow[b]{2}{*}{ Sig. } \\
\hline & & B & Std. Error & Beta & & \\
\hline 1 & (Constant) & 63.112 & 7.923 & & 7.965 & .000 \\
\hline & $\mathrm{x}$ & .553 & .074 & .843 & 7.485 & .000 \\
\hline
\end{tabular}

a. Dependent Variable: $Y$

Tabel 4.25 menjelaskan nilai standaridized cofficients atau koefisien jalur dari variabel implementasi kebijakan terhadap variabel kinerja pegawai, yaitu koefisien jalur dari $\mathrm{X}$ ke $\mathrm{Y}=$. Jika dibandingkan nilai koefisien $\rho \mathrm{YX}=0,716$ dengan sig. $=0,000$ dan $\alpha=0.05$, maka sig. $=0,000<\alpha=0.05$ menunjukkan bahwa pengaruh implementasi kebijakan terhadap kinerja adalah signifikan. 
Hasil pengolahan data dapat dibuat dalam bentuk diagram jalur dan persamaan struktural dengan menyertakan koefisien estimasi hasil pengolahan data, maka persamaan strukturalnya adalah:

$$
\begin{aligned}
& \mathrm{Y}=\beta_{1} \mathrm{X}+\varepsilon \\
& \mathrm{Y}=0.843 \mathrm{X}+\varepsilon \\
& \text { dimana : } \\
& \mathrm{X}=\text { Implementasi kebijakan } \\
& \mathrm{Y}=\text { Kinerja } \\
& \varepsilon=\text { Epsilon }
\end{aligned}
$$

Mengacu pada tabel koefisien korelasi multiple untuk struktur yang diuji menunjukkan nilai koefisien determinasi multipel dan seluruh variabel eksogenus yang diuji adalah sebesar $\mathrm{R}^{2}=71,2 \%$. Nilai determinasi multipel ini merupakan kuadrat dari nilai koefisien korelasi multipel $R=0,843$. Nilai $R^{2}$ ini menunjukkan bahwa derajat pengaruh implementsi kebijakan sangat erat jika dibandingkan dengan variabel lain yang tidak diteliti. Hasil perhitungan tersebut dapat dilihat pada gambar berikut ini:

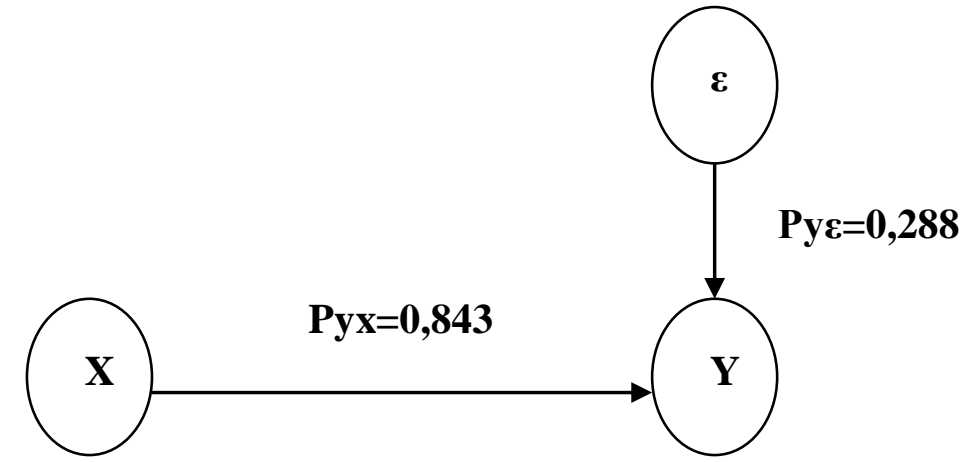

Gambar 4.11

Struktur Koefisien Jalur Variabel X ke Y 
Berdasarkan nilai-nilai koefisien jalur tersebut, selanjutnya dapat dihitung bahwa besarnya pengaruh dari variabel $\mathrm{X}$ ke $\mathrm{Y}$ adalah 0.712 yang merupakan kuadrat dari nilai koefisien $\mathrm{R}=0.843$, sedangkan besarnya pengaruh variabel lain yang tidak diteliti adalah sebesar 0.288 , untuk lebih jelasnya dapat dilihat pada gambar berikut ini :

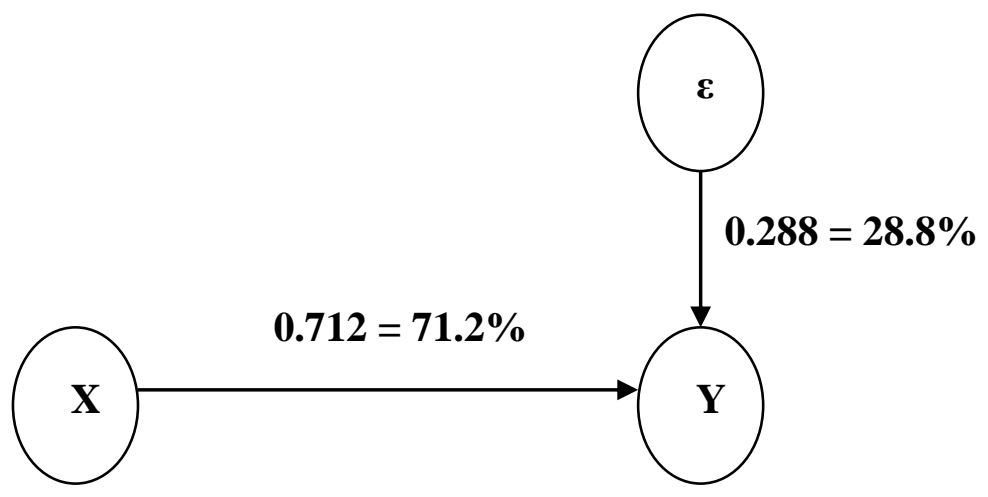

Gambar 4.12

Besarnya Pengaruh Variabel X ke Y

Besarnya nilai hubungan dan pengaruh dari variabel implementasi kebijakan terhadap kinerja pegawai dapat dijelaskan sebagai berikut:

\section{a. Hubungan antara Implementasi kebijakan(X) dengan Kinerja pegawai} (Y)

Hasil perhitungan statistika menunjukkan bahwa implementasi kebijakan memiliki hubungan kausal yang signifikan dengan kinerja pegawai sebesar $\mathrm{r}_{Y X}$ $=71,2 \%$. Implementasi kebijakan terdiri dari Standar dan Sasaran Kebijakan (X1), Sumber daya (X2), Karakteristik organisasi pelaksana (X3), Komunikasi antar organisasi pelaksana dan kegiatan-kegiatan pelaksanaan (X4), Sikap para 
pelaksana (X5), Lingkungan sosial ekonomi dan politik (X6). Sedangkan sebagai variabel terikatnya yaitu kinerja pegawai (Y) yang dilihat dari empat faktor, yaitu kualitas kerja (Y1), kuantitas kerja (Y2), keandalan (Y3) dan sikap (Y4)

\section{b. Pengaruh Implementasi Kebijakan (X) terhadap Kinerja Pegawai (Y)}

Berdasarkan hasil analisis uji kontribusi pengaruh, menunjukkan bahwa variabel implementasi kebijakan berpengaruh terhadap kinerja pegawai adalah sebesar 0.712 atau $71.2 \%$. Implementasi kebijakan terdiri dari Standar dan Sasaran Kebijakan (X1), Sumber daya (X2), Karakteristik organisasi pelaksana (X3), Komunikasi antar organisasi pelaksana dan kegiatan-kegiatan pelaksanaan (X4), Sikap para pelaksana (X5), Lingkungan sosial ekonomi dan politik (X6). Sedangkan kinerja pegawai (Y) yang dilihat dari empat faktor, yaitu kualitas kerja (Y1), kuantitas kerja (Y2), keandalan (Y3) dan sikap (Y4).

\section{c. Pengaruh Variabel lain ( $(\varepsilon)$ terhadap Kinerja Pegawai (Y)}

Implementasi kebijakan yang terdiri dari faktor komunikasi Standar dan Sasaran Kebijakan (X1), Sumber daya (X2), Karakteristik organisasi pelaksana (X3), Komunikasi antar organisasi pelaksana dan kegiatan-kegiatan pelaksanaan (X4), Sikap para pelaksana (X5), Lingkungan sosial ekonomi dan politik (X6). berpengaruh terhadap kinerja sebesar 71.2\%, sedangkan sisanya yaitu sebesar $28.8 \%$ dipengaruhi oleh variabel lain yang tidak diteliti dalam penelitian ini. 


\subsubsection{Sub Struktur X1, X2, X3, X4, X5, X6 ke Y}

Sub struktur ini diuji berapa besar pengaruh faktor komunikasi Standar dan Sasaran Kebijakan (X1), Sumber daya (X2), Karakteristik organisasi pelaksana (X3), Komunikasi antar organisasi pelaksana dan kegiatan-kegiatan pelaksanaan (X4), Sikap para pelaksana (X5), Lingkungan sosial ekonomi dan politik (X6). berpengaruh terhadap kinerja (Y) pada kantor Satuan Polisi Pamong Praja Kabupaten Subang. Metode analisis yang digunakan adalah Path Analysis. Adapun hasil Path Analysis dijelaskan pada gambar 4.13 sebagai berikut : 


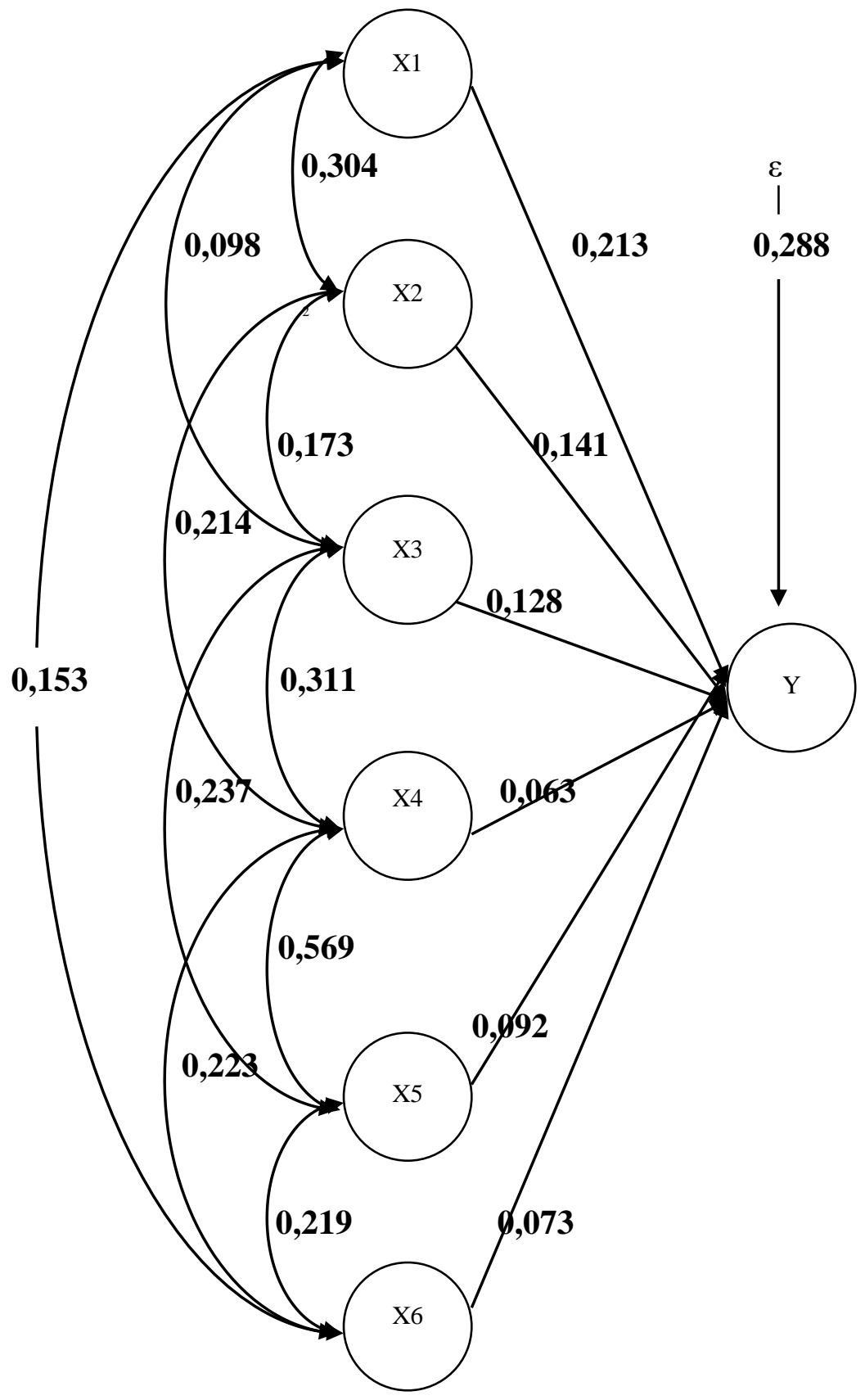

Gambar 4.13

Hasil Path Analysis Sub Struktur X1, X2, X3, X4, X5, X6 ke Y

Perhitungan-perhitungan yang dihasilkan pada Gambar 4.3 dapat dijelaskan sebagai berikut : 
4.3.2.1 Korelasi Antar Faktor komunikasi Standar dan Sasaran Kebijakan (X1), Sumber daya (X2), Karakteristik organisasi pelaksana (X3), Komunikasi antar organisasi pelaksana dan kegiatan-kegiatan pelaksanaan (X4), Sikap para pelaksana (X5), Lingkungan sosial ekonomi dan politik (X6) Berdasarkan hasil perhitungan menggunakan SPSS 17, untuk mempermudahkan peneliti didalam menghitung korelasi antar faktor. Maka hasil dari faktor Standar dan Sasaran Kebijakan (X1), Sumber daya (X2), Karakteristik organisasi pelaksana (X3), Komunikasi antar organisasi pelaksana dan kegiatankegiatan pelaksanaan (X4), Sikap para pelaksana (X5), Lingkungan sosial ekonomi dan politik (X6) adalah Sebagai Berikut :

$$
\begin{aligned}
& r_{x 1 \times 2}=0.304 \\
& r_{x 1 \times 3}=0.098 \\
& r_{x 1 \times 6}=0.158 \\
& r_{x 2 \times 3}=0.173 \\
& r_{x 2 \times 4}=0.214 \\
& r_{x 3 \times 4}=0.311 \\
& r_{x 3 \times 5}=0.237 \\
& r_{x 4 \times 5}=0.569 \\
& r_{x 4 \times 6}=0.223 \\
& r_{x 5 \times 6}=0.219
\end{aligned}
$$




\subsubsection{Pengaruh X1,X2,X3,X4,X5,X6 Terhadap Y}

Berdasarkan hasil perhitungan menggunakan SPSS 17, untuk mempermudahkan peneliti didalam menghitung besarnya pengaruh dari faktor Standar dan Sasaran Kebijakan (X1), Sumber daya (X2), Karakteristik organisasi pelaksana (X3), Komunikasi antar organisasi pelaksana dan kegiatan-kegiatan pelaksanaan (X4), Sikap para pelaksana (X5), Lingkungan sosial ekonomi dan politik (X6) terhadap kinerja pegawai (Y) adalah Sebagai Berikut :

\section{a. Pengaruh faktor Standar dan Sasaran Kebijakan (X1) Terhadap Kinerja}

\section{Pegawai (Y)}

Pengaruh faktor Standar dan Sasaran Kebijakan (X1) Terhadap Kinerja Pegawai (Y) Berdasarkan hasil perhitungan menggunakan SPSS 17, bahwa hasilnya adalah sebagai berikut :

Tabel 4.26

Pengaruh faktor Standar dan Sasaran Kebijakan (X1)

Terhadap Kinerja Pegawai (Y)

\begin{tabular}{|c|c|c|c|c|c|c|}
\hline \multicolumn{7}{|c|}{ Coefficients $^{a}$} \\
\hline \multirow{2}{*}{\multicolumn{2}{|c|}{ Model }} & \multicolumn{2}{|c|}{ Unstandardized Coefficients } & \multirow{2}{*}{$\begin{array}{c}\text { Standardized } \\
\text { Coefficients } \\
\text { Beta }\end{array}$} & \multirow[b]{2}{*}{$\mathrm{t}$} & \multirow[b]{2}{*}{ Sig. } \\
\hline & & B & Std. Error & & & \\
\hline \multirow[t]{2}{*}{1} & (Constant) & 108.320 & 5.664 & & 19.125 & .000 \\
\hline & X_1 & .877 & .354 & .461 & 2.477 & .015 \\
\hline
\end{tabular}

a. Dependent Variable: $Y$

\begin{tabular}{|c|c|c|c|c|}
\hline \multicolumn{5}{|c|}{ Model Summary } \\
\hline Model & $\mathrm{R}$ & R Square & Adjusted R Square & $\begin{array}{l}\text { Std. Error of the } \\
\text { Estimate }\end{array}$ \\
\hline 1 & $.461^{a}$ & .213 & .203 & 6.180 \\
\hline
\end{tabular}

a. Predictors: (Constant), X_1 
Berdasarkan tabel 4.26 bahwa faktor Standar dan Sasaran Kebijakan (X1) berpengaruh Terhadap Kinerja Pegawai (Y) secara signifikan ditunjukan dengan sig 0.015 dan $a=0.05$, berarti $0.015<0.05$ maka besarnya pengaruh Standar dan Sasaran Kebijakan (X1) Terhadap Kinerja Pegawai (Y) sebesar 0.213 yang berarti faktor faktor Standar dan Sasaran Kebijakan berpengaruh sebesar 21,3 \% terhadap kinerja pegawai.

\section{b. Pengaruh faktor Sumber daya (X2) Terhadap Kinerja Pegawai (Y)}

Pengaruh faktor faktor Sumber daya (X2) Terhadap Kinerja Pegawai (Y) Berdasarkan hasil perhitungan menggunakan SPSS 17, bahwa hasilnya adalah sebagai berikut :

Tabel 4.27

Pengaruh faktor Sumber daya (X2) Terhadap Kinerja Pegawai (Y)

\begin{tabular}{|c|c|c|c|c|c|c|}
\hline \multicolumn{7}{|c|}{ Coefficients $^{a}$} \\
\hline \multirow{2}{*}{\multicolumn{2}{|c|}{ Model }} & \multicolumn{2}{|c|}{ Unstandardized Coefficients } & $\begin{array}{l}\text { Standardized } \\
\text { Coefficients }\end{array}$ & \multirow[b]{2}{*}{$\mathrm{t}$} & \multirow[b]{2}{*}{ Sig. } \\
\hline & & B & Std. Error & Beta & & \\
\hline 1 & (Constant) & 105.310 & 5.672 & & 18.567 & .000 \\
\hline & $x \_2$ & 1.111 & 369 & .375 & 3.009 & .003 \\
\hline
\end{tabular}

a. Dependent Variable: Y

\begin{tabular}{|c|c|c|c|c|}
\hline \multicolumn{5}{|c|}{ Model Summary } \\
\hline Model & $\mathrm{R}$ & R Square & $\begin{array}{l}\text { Adjusted R } \\
\text { Square }\end{array}$ & $\begin{array}{c}\text { Std. Error of the } \\
\text { Estimate }\end{array}$ \\
\hline 1 & $.375^{\mathrm{a}}$ & .141 & .131 & 8.060 \\
\hline
\end{tabular}

a. Predictors: (Constant), X_2 
Berdasarkan tabel 4.27 bahwa faktor sumber daya (X2) berpengaruh terhadap kinerja pegawai (Y) secara signifikan ditunjukan dengan sig 0.003dan $\mathrm{a}=0.05$, berarti $0.003<0.05$ maka besarnya pengaruh sumber daya terhadap kinerja pegawai (Y) sebesar 0.141 yang berarti faktor faktor Standar dan Sasaran Kebijakan berpengaruh sebesar $14.1 \%$ terhadap kinerja pegawai

\section{c. Pengaruh faktor Karakteristik organisasi pelaksana (X3) Terhadap}

\section{Kinerja Pegawai (Y)}

Pengaruh faktor Karakteristik organisasi pelaksana (X3) Terhadap Kinerja Pegawai (Y). Berdasarkan hasil perhitungan menggunakan SPSS 17, bahwa hasilnya adalah sebagai berikut :

Tabel 4.28

Pengaruh faktor Karakteristik organisasi pelaksana (X3) Terhadap Kinerja Pegawai (Y)

\begin{tabular}{|c|c|c|c|c|c|c|}
\hline \multicolumn{7}{|c|}{ Coefficients $^{a}$} \\
\hline \multirow{2}{*}{\multicolumn{2}{|c|}{ Model }} & \multicolumn{2}{|c|}{ Unstandardized Coefficients } & \multirow{2}{*}{$\begin{array}{c}\text { Standardized } \\
\text { Coefficients } \\
\text { Beta }\end{array}$} & \multirow[b]{2}{*}{$\mathrm{t}$} & \multirow[b]{2}{*}{ Sig. } \\
\hline & & B & Std. Error & & & \\
\hline 1 & (Constant) & 86.851 & 7.072 & & 12.281 & .000 \\
\hline & X_3 & 2.431 & .484 & .359 & 5.028 & .000 \\
\hline
\end{tabular}

a. Dependent Variable: $Y$

\begin{tabular}{|c|r|r|r|r|}
\hline \multicolumn{1}{|c|}{ Model Summary } \\
\hline Model & $\mathrm{R}$ & $\mathrm{R}$ Square & $\begin{array}{l}\text { Adjusted R } \\
\text { Square }\end{array}$ & $\begin{array}{c}\text { Std. Error of the } \\
\text { Estimate }\end{array}$ \\
\hline 1 & $.359 \mathrm{a}$ & .128 & .118 & 7.477 \\
\hline
\end{tabular}

a. Predictors: (Constant), X_3 
Berdasarkan tabel 4.28 bahwa faktor karakteristik organisasi pelaksana (X3) berpengaruh terhadap kinerja pegawai (Y) secara signifikan ditunjukan dengan sig 0.000 dan $\mathrm{a}=0.05$, berarti $0.000<0.05$ maka besarnya pengaruh karakteristik organisasi pelaksana terhadap kinerja pegawai sebesar 0.128 yang berarti faktor faktor Standar dan Sasaran Kebijakan berpengaruh sebesar $12.8 \%$ terhadap kinerja pegawai.

\section{d. Pengaruh faktor Komunikasi antar organisasi pelaksana dan kegiatan-}

\section{kegiatan pelaksanaan (X4) terhadap kinerja pegawai (Y)}

Pengaruh faktor Komunikasi antar organisasi pelaksana dan kegiatankegiatan pelaksanaan (X4) terhadap kinerja pegawai (Y). Berdasarkan hasil perhitungan menggunakan SPSS 17, bahwa hasilnya adalah sebagai berikut :

Tabel 2.29

Pengaruh faktor Komunikasi antar organisasi pelaksana dan kegiatankegiatan pelaksanaan (X4) terhadap kinerja pegawai (Y)

\begin{tabular}{|c|c|c|c|c|c|c|}
\hline \multicolumn{7}{|c|}{ Coefficients $^{a}$} \\
\hline \multirow{2}{*}{\multicolumn{2}{|c|}{ Model }} & \multicolumn{2}{|c|}{ Unstandardized Coefficients } & \multirow{2}{*}{$\begin{array}{c}\text { Standardized } \\
\text { Coefficients } \\
\text { Beta }\end{array}$} & \multirow[b]{2}{*}{$\mathrm{t}$} & \multirow[b]{2}{*}{ Sig. } \\
\hline & & B & Std. Error & & & \\
\hline \multirow[t]{2}{*}{1} & (Constant) & 94.480 & 5.810 & & 16.262 & .000 \\
\hline & $X \_4$ & 1.141 & .237 & .251 & 4.814 & .000 \\
\hline
\end{tabular}

a. Dependent Variable: $Y$

\begin{tabular}{|l|r|r|r|r|}
\multicolumn{7}{|c|}{ Model Summary } \\
\hline Model & $\mathrm{R}$ & $\mathrm{R}$ Square & $\begin{array}{c}\text { Adjusted R } \\
\text { Square }\end{array}$ & $\begin{array}{c}\text { Std. Error of the } \\
\text { Estimate }\end{array}$ \\
\hline 1 & $.251^{\mathrm{a}}$ & .063 & .053 & 7.546 \\
\hline
\end{tabular}

a. Predictors: (Constant), X_4 
Berdasarkan tabel 2.29 bahwa faktor komunikasi antar organisasi pelaksana dan kegiatan-kegiatan pelaksanaan berpengaruh terhadap kinerja pegawai (Y) secara signifikan ditunjukan dengan sig 0.000 dan $\mathrm{a}=0.05$, berarti $0.000<0.05$ maka besarnya pengaruh komunikasi antar organisasi pelaksana dan kegiatan-kegiatan pelaksanaan terhadap kinerja pegawai sebesar 0.063 yang berarti faktor faktor Standar dan Sasaran Kebijakan berpengaruh sebesar $6.3 \%$ terhadap kinerja pegawai.

\section{e. Pengaruh faktor sikap para pelaksana (X5) terhadap kinerja pegawai (Y)}

Pengaruh faktor sikap para pelaksana (X5) terhadap kinerja pegawai (Y). Berdasarkan hasil perhitungan menggunakan SPSS 17, bahwa hasilnya adalah sebagai berikut :

Tabel 2.30

Pengaruh faktor sikap para pelaksana (X5) terhadap kinerja pegawai (Y)

\begin{tabular}{|c|c|c|c|c|c|c|}
\hline \multicolumn{7}{|c|}{ Coefficients $^{a}$} \\
\hline \multirow{2}{*}{\multicolumn{2}{|c|}{ Model }} & \multicolumn{2}{|c|}{ Unstandardized Coefficients } & $\begin{array}{l}\text { Standardized } \\
\text { Coefficients }\end{array}$ & \multirow[b]{2}{*}{$\mathrm{t}$} & \multirow[b]{2}{*}{ Sig. } \\
\hline & & B & Std. Error & Beta & & \\
\hline 1 & (Constant) & 95.949 & 6.446 & & 14.886 & .000 \\
\hline & $\times 5$ & 1.147 & 279 & .304 & 4.104 & .000 \\
\hline
\end{tabular}

a. Dependent Variable: $Y$

\begin{tabular}{|c|r|r|r|r|}
\hline & & & \multicolumn{1}{|c|}{ Model Summary } \\
Model & $\mathrm{R}$ & $\mathrm{R}$ Square & \multicolumn{1}{c|}{$\begin{array}{c}\text { Square } \\
\text { Square }\end{array}$} & $\begin{array}{c}\text { Std. Error of the } \\
\text { Estimate }\end{array}$ \\
\hline 1 & $.304 \mathrm{a}$ & .092 & .082 & 7.764 \\
\hline
\end{tabular}

a. Predictors: (Constant), X_5 
Berdasarkan tabel 2.30 bahwa faktor sikap para pelaksana berpengaruh terhadap kinerja pegawai (Y) secara signifikan ditunjukan dengan sig 0.000 dan $\mathrm{a}=0.05$, berarti $0.000<0.05$ maka besarnya pengaruh sikap para pelaksana terhadap kinerja pegawai sebesar 0.092 yang berarti faktor faktor Standar dan Sasaran Kebijakan berpengaruh sebesar 9.20\% terhadap kinerja pegawai

\section{f. Pengaruh faktor lingkungan sosial ekonomi dan politik (X6) terhadap}

\section{kinerja pegawai (Y)}

Pengaruh faktor lingkungan sosial ekonomi dan politik (X6) terhadap kinerja pegawai (Y). Berdasarkan hasil perhitungan menggunakan SPSS 17, bahwa hasilnya adalah sebagai berikut :

Tabel 2.31

Pengaruh faktor lingkungan sosial ekonomi dan politik (X6) terhadap kinerja pegawai (Y)

\begin{tabular}{|c|c|c|c|c|c|c|}
\hline \multicolumn{7}{|c|}{ Coefficients $^{a}$} \\
\hline \multirow{2}{*}{\multicolumn{2}{|c|}{ Model }} & \multicolumn{2}{|c|}{ Unstandardized Coefficients } & \multirow{2}{*}{$\begin{array}{c}\begin{array}{c}\text { Standardized } \\
\text { Coefficients }\end{array} \\
\text { Beta }\end{array}$} & \multirow[b]{2}{*}{$\mathrm{t}$} & \multirow[b]{2}{*}{ Sig. } \\
\hline & & B & Std. Error & & & \\
\hline 1 & (Constant) & 100.349 & 4.581 & & 21.906 & .000 \\
\hline & X_6 & 1.554 & .321 & .272 & 4.839 & .000 \\
\hline
\end{tabular}

a. Dependent Variable: $Y$

\begin{tabular}{|l|r|r|r|c|}
\hline & & & \multicolumn{1}{c|}{ Model Summary } \\
\hline Model & $\mathrm{R}$ & $\mathrm{R}$ Square & \multicolumn{1}{c|}{$\begin{array}{c}\text { Square } \\
\text { Square }\end{array}$} & $\begin{array}{c}\text { Std. Error of the } \\
\text { Estimate }\end{array}$ \\
\hline 1 & $.272^{\mathrm{a}}$ & .073 & .063 & 7.537 \\
\hline
\end{tabular}

a. Predictors: (Constant), X_6 
Berdasarkan tabel 2.31 bahwa faktor lingkungan sosial ekonomi dan politik berpengaruh terhadap kinerja pegawai (Y) secara signifikan ditunjukan dengan sig 0.000 dan $\mathrm{a}=0.05$, berarti $0.000<0.05$ maka besarnya pengaruh lingkungan sosial ekonomi dan politik terhadap kinerja pegawai sebesar 0.073 yang berarti faktor faktor Standar dan Sasaran Kebijakan berpengaruh sebesar $7.30 \%$ terhadap kinerja pegawai.

\subsection{Pembahasan Secara Simultan Pengaruh Implementasi Kebijakan Terhadap Kinerja Pegawai Di Kantor Satuan Polisi Pamong Praja Kabupaten Subang}

Berdasarkan hasil penelitian dapat diperoleh gambaran bahwa secara simultan bentuk pengaruh antar variabel telah sesuai dengan hipotesis yang dikemukakan. Implementasi kebijakan yang diukur dengan Standar dan Sasaran Kebijakan, Sumber daya, Karakteristik organisasi pelaksana, Komunikasi antar organisasi pelaksana dan kegiatan-kegiatan pelaksanaan, Sikap para pelaksana, Lingkungan sosial ekonomi dan politik berpengaruh terhadap kinerja pegawai pada satuan polisi pamong praja kabupaten subang. Besarnya pengaruh implementasi kebijakan tersebut adalah sebesar 71.2\%, selebihnya dipengaruhi oleh faktor yang lain.

Peneliti mengungkapkan bawha implementasi kebijakan di lingkungan kantor satuan polisi pamong praja kabupaten subang dipandang sebagai faktor pendukung guna meningkatkan kinerja pegawai. Hal ini didasari bahwa lahirnya suatu kebijakan merupakan suatu arahan tindakan nyata yang harus dilakukan 
pemerintah dan mempunyai tujuan untuk mengatasi masalah atau permasalahan yang ada di dalam masyarakat maupun organisasi. Sementara implementasi kebijakan merupakan pelaksana dan pengendalian arah tindakan untuk pencapaian tujuan.

Implementasi kebijakan yang akan dilaksanakan oleh satuan polisi pamong praja belum dapat sepenuhnya dilaksanakan karena disebabkan ada beberapa faktor-faktor yang belum terpenuhi, seperti satuan polisi pamong praja komunikasi antar organisasi pelaksana dan kegiatan-kegiatan pelaksana, sikap para pelaksana, disertai dengan lingkungan sosial, ekonomi dan politik.

Peneliti membandingkan dengan penelitian-penelitian sebelumnya yang membahas tentang pengaruh implementasi kebijakan terhadap kinerja pegawai, bahwa telah terbukti secara empiris bahwa ke enamt faktor yaitu Standar dan Sasaran Kebijakan, Sumber daya, Karakteristik organisasi pelaksana, Komunikasi antar organisasi pelaksana dan kegiatan-kegiatan pelaksanaan, Sikap para pelaksana, Lingkungan sosial ekonomi dan politik berpengaruh terhadap kinerja pegawai dan juga mempunyai pengaruh yang signifikan terhadap peningkatan kinerja pegawai.

Teori-teori yang digunakan oleh peneliti dalam penelitian ini pun hasilnya tidak jauh jika dibandingkan dengan realita di lapangan. Terbukti bahwa antara kebijakan dengan kinerja pegawai itu saling berkaitan dan implementasi kebijakan terbukti secara empiris mempengaruhi kinerja pegawai di suatu organisasi atau instansi. 
Hasil temuan penelitian yang berkaitan dengan rendahnya kinerja pegawai, kantor satuan polisi pamong praja Kabupaten Subang. Ditunjukan oleh kualitas kerja, kuantitas kerja, keandalan dan sikap. Bahwa hasil penelitian faktor implementasi kebijakan di lingkungan kantor satuan polisi pamong praja kabupaten subang dipandang sebagai salah satu faktor pendukung guna meningkatkan kinerja pegawai. Dari temuan yang ada dapat terlihat bahwa implementasi kebijakan penertiban pedagang kaki lima tidak dapat diimplementasikan sepenuhnya karena belum terpenuhinya beberapa faktor-faktor implementasi kebijakan. Hal tersebut mempengaruhi terhadap kinerja pegawai di kantor satuan polisi pamong praja kabupaten subang. Sesuai hasil wawancara peneliti dengan kepala satuan polisi pamong praja kabupaten subang, peneliti menimpulkan, bahwa dalam upaya untuk memeprbaiki permasalahan tersebut dan untuk mengatasinya sekaligus meningkatkan kinerja pegawai satuan polisi pamong praja, maka akan diselenggarakannya pendidikan dan pelatihan, untuk meningkatkan sumber daya manusia dengan memperbolehkan dan mewajibkan para pegawainya untuk melanjutkan kejenjang yang lebih tinggi lagi dalam bidang pendidikannya, penempatan para pegawai yang sesuai dengan fungsi, tugas dan tanggungjawabnya serta menjalin hubungan dan komunikasi dengan instansi/organisasi dengan baik sehingga dalam proses pelaksanan kebijakan dari setiap program pelaksanaan kebijakan dapat efesien dan efektif. 


\subsection{Pembahasan Secara Parsial Implementasi Kebijakan Terhadap Kinerja}

\section{Pegawai}

\subsubsection{Faktor Standar dan Sasaran Kebijakan}

Hipotesis yang diajukan peneliti bahwa implementasi kebijakan diukur melalui faktor standar dan sasaran kebijakan (X1) besarnya pengaruh terhadap kinerja pegawai (Y). Hasil pengolahan data menunjukan bahwa faktor standar dan sasaran kebijakan berpengaruh signifikan terhadap kinerja pegawai adalah sebesar 0,213 atau $21,3 \%$.

Faktor standar dan sasaran kebijakan menunjukan peranan penting sebagai acuan agar pelaksanaan kebijakan mengetahui persis apa yang akan mereka kerjakan. Faktor standar dan sasaran kebijakan dapat diartikan bahwa tingkat kemajemukan dari kelompok sasaran, ini berarti suatu program akan relatif mudah diimplementasikan apabila kelompok sasarannya homogen. Sebaliknya, apa bila kelompok sasaran heterogen, maka implementasi program akan relatif sulit, karena tingkat pemahaman setiap anggota kelompok sasaran terhadap program relatif berbeda.

Kinerja Satuan Polisi Pamong Praja, sudah melakukan perannnya untuk melaksanakan programnya yaitu penertiban pedagang kaki lima dengan secara efektif karena standar dan sasaran kebijakannya sudah jelas dan terukur sehingga dapat direalisir. 


\subsubsection{Faktor Sumber daya}

Hipotesis yang diajukan peneliti bahwa implementasi kebijakan diukur melalui faktor sumber daya (X2) besarnya pengaruh terhadap kinerja pegawai (Y). Hasil pengolahan data menunjukan bahwa faktor sumber daya berpengaruh signifikan terhadap kinerja pegawai adalah sebesar 0,141 atau $14,1 \%$.

Faktor sumber daya merupakan faktor penting dalam proses pelaksanaan suatu implementasi kebijakan, implementasi kebijakan perlu dukungan sumber daya baik sumber daya manusia maupun sumber daya non-manusia atau sumber daya finansial. Besarnya alokasi sumber daya finansial terhadap kebijakan merupakan faktor kursial untuk sebuah program sosial. Setiap program juga membutuhkan atau memerlukan dukungan dari setiap sumber daya manusia untuk melakukan pekerjaan-pekerjaan administrasi dan teknis, serta memonitor program, yang semuanya itu perlu biaya. Namun dalam konteks pelaksanaan implementasi kebijakan yang dilaksanakan oleh Satuan Polisi Pamong Praja Kabupaten Subang, sudah sepenuhnya dilaksanakan dengan efektif. Akan tetapi faktor sumber daya ini belum bisa memeberikan dampak yang positif dalam pencapaian pelaksanaan tujuan implementasi kebijakan. Disebabkan ada beberapa pemasalahan yang menghempitnya dalam proses pelaksanaan kebijakan terutama sumber daya manusia yang belum optimal atau kurang handal dari beberapa pegawai satuan polisi pamong itu sendiri yang mempunyai latar pendidikan yang berbeda-beda, serta sumber daya finansial benar-benar belum memadai demi terselengarakannya suatu program pelaksanana implementasi kebijakan yaitu 
dalam hal penertiban padagang kaki lima. Seiring dengan penertiban pedagang kaki lima ini, biaya finansial yang sering dikeluar oleh satuan polisi pamong praja kabupaten tidak hanya sedikit melainkan mengeluarkan anggaran begitu besar. Ada beberapa program implementasi kebijakan yang belum dapat dilaksanakan dikarena oleh keterbatasan sumber daya manusia, dan hal yang paling mencolok adalah sumber daya finansial atau anggaran, sehingga satuan polisi pamong praja harus bisa membuat skala prioritas dalam pelaksanaan implementasi kebijakan.

\subsubsection{Faktor Karakteristik organisasi pelaksana}

Hipotesis yang diajukan peneliti bahwa implementasi kebijakan diukur melalui faktor Karakteristik organisasi pelaksana (X3) besarnya pengaruh terhadap kinerja pegawai (Y). Hasil pengolahan data menunjukan bahwa faktor Karakteristik organisasi pelaksana berpengaruh signifikan terhadap kinerja pegawai adalah sebesar 0,128 atau $12,8 \%$.

Faktor karakteristik organisasi pelaksana dapat diartikan bahwa untuk mencapai suatu program implementasi kebijakan perlu dukungan stuktur organisasi, hubungan dan komunikasi internal birokrasi yang baik. Sebagaimana mestinya faktor karakteristik organisasi pelaksana ini merupakan faktor yang penting dalam pelaksanakan program implementasi kebijakan. Peranan satuan polisi pamong praja kabupaten subang mempunyai andil hubungan dan komunikasi untuk saling mendukung dalam struktur organisasi dengan struktur organisasi yang lainya dan instansi yang terkait. 
Pelaksanaan program implementasi kebijakan dalam hal penertiban pedagang kaki lima yang dilakukan oleh satuan polisi pamong praja kabupaten subang sebelum melaksanakan penertiban pedagang kaki lima selalu berhubungan terelebih dahulu dan berkomunikasi dengan internal birokrasi yang terkait sehingga proses pelaksanaan implementasi kebijakan penertiban pedagang kaki lima dapat dilaksanakan secara efektif. Akan tetapi satuan polisi pamong praja masih mempunyai kesulitan untuk berhubungan dan berkomunikasi internal dengan birokrasi, disebabkan pula dikarenakan ada beberapa struktur organisasi maupun birokrasi yang mempunyai keterkaitan suatu kepentingan individu sebelum mereka melaksanakan tujuan organisasinya.

\subsubsection{Faktor Komunikasi antar organisasi pelaksana dan kegiatan-kegiatan pelaksanaan}

Hipotesis yang diajukan peneliti bahwa implementasi kebijakan diukur melalui faktor Komunikasi antar organisasi pelaksana dan kegiatan-kegiatan pelaksanaan (X4) besarnya pengaruh terhadap kinerja pegawai (Y). Hasil pengolahan data menunjukan bahwa faktor Komunikasi antar organisasi pelaksana dan kegiatan-kegiatan pelaksanaan berpengaruh signifikan terhadap kinerja pegawai adalah sebesar 0,063 atau $6,3 \%$.

Faktor komunikasi antar organisasi pelaksana dan kegiatan-kegiatan pelaksana merupakan faktor penting yang harus dilaksanakan oleh satuan polisi pamong praja, selain itu juga faktor ini merupakan faktor yang mempunyai dampak dalam pelaksanaan kebijakan, sebab keberhasilan suatu program 
implementasi kebijakan dengan adanya faktor koordinasi dan kerja sama yang baik antar organisasi maupun satuan polisi pamong praja itu sendiri. Namun sangat disayangkan proses koordinasi baik secara vertikal maupun horisontal antar instansi maupun pegawai satuan polisi pamong praja serta kerjasamanya kurang efektif. Akan tetapi selebihnya proses pelaksanaan kebijakan penertiban pedangan kaki lima dengan adanya standar operating prosedur (SOP) dan hanya sebagian kecil saja satuan polisi pamong praja yang belum memahami tentang SOP, tetapi arah dan pencapaian pelaksanaan penertiban yang dilakukan oleh satuan polisi pamong praja kurang dapat dilaksanakan secara optimal. sehingga satuan polisi pamong praja telah menerapkan standar operating prosedur demi mempermudahkan mereka dalam melaksanakan pencapaian tujuan organisasinya walaupun dalam prakteknya dilapangan terkadang beberapa hal yang tidak bisa benar-benar sesuai dengan SOP.

\subsubsection{Faktor Sikap para pelaksana}

Hipotesis yang diajukan peneliti bahwa implementasi kebijakan diukur melalui faktor Sikap para pelaksana (X5) besarnya pengaruh terhadap kinerja pegawai (Y). Hasil pengolahan data menunjukan bahwa faktor Sikap para pelaksana berpengaruh signifikan terhadap kinerja pegawai adalah sebesar 0,092 atau $9,2 \%$.

Faktor sikap para pelaksana harus mempunyai kejelasan dan konsisten aturan yang ada pada para pelaksana, maksudnya adalah tingkat komitmen satuan polisi pamong praja terhadap tujuan kebijakan. Faktor sikap para pelaksana ini 
merupakan faktor penting sebab mencerminkan bagaimana satuan polisi pamong praja menyingkapi permasalahan yang ada dilapangan dan melaksanakan tugas mereka dalam menertibkan pedagang kaki atau pelaksanaan program implementasi kebijakan yang sedang mereka hadapi.

Faktor sikap para pelaksana telah dilaksanakan disatuan polisi pamong praja, dengan membuat prioritas tujuan dan merealisasikan tujuan dengan mengkaidahkan proses pelaksanaan implementasi kebijakan secara antusias, responsif dan demokrasi. Namun dalam hal demokrasi kurang bisa dilakukan oleh satuan polisi pamong praja dikarenakan demokrasi ini lah yang menghambat proses penertiban pedagang kaki lima atau pelaksanaan implementasi kebijakan yang sedang dilakukan oleh satuan polisi pamong praja. Proses pelaksanaan implementasi kebijakan merupakan hal yang wajib harus ditegaskan dan ditegakan oleh satuan polisi pamong praja.

\subsubsection{Faktor Lingkungan sosial, ekonomi, dan politik}

Hipotesis yang diajukan peneliti bahwa implementasi kebijakan diukur melalui faktor Lingkungan sosial, ekonomi, dan politik (X6) besarnya pengaruh terhadap kinerja pegawai (Y). Hasil pengolahan data menunjukan bahwa faktor Lingkungan sosial, ekonomi, dan politik berpengaruh signifikan terhadap kinerja pegawai adalah sebesar 0,073 atau $7,3 \%$

Faktor lingkungan sosial, ekonomi dan politik merupakan faktor penting dalam pelaksanaan implementasi kebijakan. Kinerja satuan polisi pamong praja benar-benar dipengaruhi oleh faktor lingkungan sosial, ekonomi dan politik. 
Tercapainya pelaksanaan implementasi kebijakan dalam penertiban pedagang kaki lima yang dilakukan oleh satuan polisi pamong praja sudah bisa memberikan arti yang positif bila para elit politik dan kelompok-kelompok tertentu saling bila saling memberikan dukungan.

\subsection{Faktor Lain yang Mempengaruhi Kinerja Pegawai diluar Variabel Implementasi Kebijakan}

Adapun faktor lainnya yang disinyalir ikut mempengaruhi diantaranya yaitu : Pengawasan, Insentif, Perilaku Organisasi, Kepemimpinan. Peneliti melihat bahwa keempat faktor itu mempunyai potensi dalam mempengaruhi kinerja pegawai satuan polisi pamong praja kabupaten Subang. 


\section{BAB V}

\section{KESIMPULAN DAN SARAN}

\subsection{Kesimpulan}

Berdasarkan hasil penelitian tentang Pengaruh Implementasi Kebijakan terhadap Kinerja Pegawai Di Kantor Satuan Polisi Pamong Praja Kabupaten Subang, (Studi Implementasi Kebijakan Tentang Peraturan Daerah Kab. Subang No. 13 Tahun 2006 Tentang Ketertiban, Kebersihan, dan Keindahan) yang telah dikemukakan pada deskripsi dan pembahasan, maka secara komprehensif peneliti dapat menyimpulkan hasil penelitian sebagai berikut:

1. Impelementasi kebijakan cukup kuat dan signifikan terhadap kinerja pegawai,

2. Implementasi Kebijakan yang terdiri dari Faktor Standar dan Sasaran Kebijakan menunjukkan pengaruh yang paling besar terhadap kinerja pegawai, selanjutnya diikuti oleh faktor Sumber daya, faktor Karakteristik organisasi pelaksana, faktor Sikap para pelaksana, faktor Lingkungan sosial ekonomi dan politik. Sedangkan pengaruh yang terkecil terhadap kinerja pegawai adalah dari faktor Komunikasi antar organisasi pelaksana dan kegiatan-kegiatan pelaksanaan.

3. Selain Implementasi kebijakan dan kinerja pegawai juga dipengaruhi oleh faktor lain yang tidak diteliti pada penelitian ini.

\subsection{Saran}

Berdasarkan temuan penelitian, peneliti dapat menyampaikan saran-saran penelitian yang diharapkan dapat menjadi rekomendasi, baik dalam konteks 
pengembangan ilmu maupun sebagai kontribusi bagi implementasi kebijakan yang berdampak pada kinerja. Adapun saran yang dimaksud antara lain:

\subsubsection{Saran Akademik}

Peneliti/Penulis menyarankan perlu dilakukan penelitian lanjutan tentang fenomena belum sepenuhnya dilaksanakan implementasi kebijakan dan kinerja pegawai, khususnya ditinjau dari perspektif ilmu kebijakan publik. Fenomena tersebut diperkuat oleh adanya faktor lain yang tidak diteliti di luar dari penelitian ini, namun mempengaruhi kinerja pegawai. Temuan ini dapat dijadikan bahan penelitian lanjutan berkaitan dengan pengaruh berbagai faktor terhadap kinerja pegawai.

\subsubsection{Saran Praktis}

Perlu adanya pemahaman yang lebih komprehensif tentang implementasi kebijakan, khususnya berkaitan dengan peningkatan faktor Komunikasi antar organisasi pelaksana dan kegiatan-kegiatan pelaksanaan. Sehubungan dengan masih lemahnya aspek tersebut dalam mempengaruhi kinerja pegawai, maka perlu adanya pengkajian yang lebih mendalam dan fragmentasi. Dengan adanya peningkatan faktor Komunikasi antar organisasi pelaksana dan kegiatan-kegiatan pelaksanaan diharapkan tercapai optimalisasi kinerja pegawai pada Kantor Satuan Polisi Pamong Praja Kab. Subang. Selain itu juga pentingnya membangun sumber daya manusia dengan mengadakan pendidikan dan pelatihan kepada para pegawai satuan polisi pamong praja kab. Subang selain untuk menjadi pegawai yang lebih handal, maka peranan kerjasama dan komunikasi dengan instansi yang lain perlu 
ditingkatkan serta partisipasi masyarakat perlu dilibatkan dalam pengimplementasian kebijakan ini.

Berkaitan dengan temuan tersebut dipandang layak untuk meningkatkan keefektifan proses implementasi kebijakan agar menjadi semakin lebih optimal yang bertujuan untuk meningkatkan kualitas kinerja dalam rangka menyukseskan penertiban pedagang kaki lima.

\subsubsection{Saran Kebijakan}

Faktor Komunikasi antar organisasi pelaksana dan kegiatan-kegiatan pelaksanaan menunjukkan pengaruh yang kecil terhadap kinerja pegawai. Dengan demikian, peningkatan kualitas Komunikasi antar organisasi pelaksana dan kegiatan-kegiatan pelaksanaan khususnya dalam pelaksanaan Standard Operating Procedure (SOP) selayaknya menjadi prioritas agar kinerja pegawai semakin handal. Peneliti menyarankan harus adanya suatu peraturan yang menjelaskan tentang Standard Operating Procedure (SOP) supaya proses pelaksanaan suatu kebijakan dapat berjalan secara efektif. 


\section{DAFTAR PUSTAKA}

Anderson, James E. 1979. Public Policy Making. New York: Holt, Rinehart and Winston.

Dunn, William N. 2000. Pengantar Analisis Kebijakan Publik. (Penerjemah:Muhadjir). Gajah Mada University Press. Yogyakarta.

Dessler. 1997. Manajemen Sumber Daya Manusia. Edisi Bahasa Indonesia Jilid 2. PT. Prenhallindo. Jakarta.

Dye, Thomas R. 1976. Policy Analsis : What Governments Do, Whya They Do it and What Difference it makes. The University Alabama.

Fermana, Surya. 2009. Kebijakan Publik : Sebuah Tinjauan Filosfis. Ar-Ruzz Media. Jogjakarta.

Gibson, Ivancevich, dan Donelly. 1996. Organisasi. Jakarta. Binarupa Aksara.

Harists, Benjamin. 2005. Teori Organisasi jilid 1, 2, dan 3. Insani Press. Bandung.

Hariwijaya, M. Dan Djaelani M. Bisri. 2004. Teknik Penulisan Skripsi dan Tesis. Hanggar Kreator. Yogyakarta.

Hasibuan, Malayu. 2008. Manajemen: Dasar, Pengertian, dan Masalah. Edisi Revisi. Jakarta : PT. Bumi Aksara.

Indiahono, Dwiyanto. 2009. Perbandingan Administrasi Publik. Gava Media. Yogyakarta.

Islamy, M. Irfan. 2000-cetakan kesembilan. Prinsip-prinsip Perumusan Kebijakan Negara. Bumi Aksara. Jakarta.

Kartono, Kartini. 2005. Kepemimpinan: Apakah Kepemimpian Abnormal itu?. PT.Raja Grafindo Persada. Jakarta. 
Keban, Yaremis T. 1995. Indikator Kinerja Pemda: Pendekatan Manajemen dan Kebijakan. Makalah. Yogyakarta.

Kerlinger, Freed N. 1990. Asas-asas Penelitian Behavioral: Terjemahan. Gajah Mada University Press. Yogyakarta.

Kumoroto, Wahyudi. 2001. Etika Administrasi Negara. Raja Grafindo Persada. Jakarta. . 2001. Meningkatkan Kinerja Bumn: Antisipasi Terhadap Kompetisi dan Kebijakan Dergulasi. JKAP No.1. Yogyakarta.

Lembaga Administrasi Negara RI. 1994. Sistem Administrasi Negara Republik Indonesia. Cv. Haji Masangung. Jakarta.

Mangkunegara, Anwar Prabu. 2003. Prencanaan dan Pengembangan Sumber Daya Manusia. Refika Aditama. Jakarta.

Mutopadidjadja, AR. 2002. Manajemen Kebijakan Publik. LAN. Jakarta.

Naihasy, H. Syharin. 2006. Kebijakan Publik (public Policy) Menggapai Masyarakat Madani. Mida Pustaka. Yogyakarta.

Napitupulu, Paimin. 2008. Buku Pembelajaran Ekologi Administrasi Negara. PT.Alumni.Bandung.

Ndraha, Taliziduhu. 2005. Teori Budaya Organisasi.PT. Rineka Cipta. Jakarta

Nugroho Riant.2003. Kebijakan Publik Formulasi, Implementasi dan Evaluasi.Gramedia. Jakarta.

Pamudji, S. 2004. Ekologi Administrasi Negara. Bumi Aksara. Jakarta

Pasolong, Harbani. 2008. Teori Administrasi Publik.Alfabeta. Bandung.

Parson, Wayne. 2006-cetakan kedua. Public Policy. Pengantar Teori dan Praktek Analisis Kebijakan. Kencana. Jakarta. 
Priyatno, Duwi.2009.5 Jam Belajar Olah Data dengan SPSS17.ANDI offset.Yogyakarta

Ranupandojo, H, Suad Husnan. 2000. Manajemen Sumber Daya Manusia. Yogyakarta: BPFE-UGM.

Robbins, Stephen P. 1994. Teori Organisasi, Struktur, Desain dan Aplikasi. Penerjemah:Jusup Udaya. Arcan. Jakarta.

Santoso, Singgih.2006. Menggunakan SPSS untuk Statistik Parametrik. Gramedia.Jakarta.

Siagian, Sondang P. 1992. Kerangka Dasar Ilmu Administrasi. Rineka Cipta. Jakarta.

1997. Organisasi, Kepemimpinan dan Perilaku Administrasi. PT. Toko Gunung Agung. Jakarta.

2006. Manajemen Sumber Daya Manusia. Jakarta: Penerbit Bumi Aksara.

2007. Teori Pengembangan Organisasi. Jakarta : Penerbit Bumi Aksara.

Silalahi, Ulbert. 2007. Studi Tentang Ilmu Administrasi: Konsep, Teori dan Dimensi. Sinar Baru Algensindo. Bandung. 2009. Metode Penelitian Sosial. Refika Aditama. Bandung.

Subarsono, AG. 2008. Analisis Kebijakan Publik Konsep, Teori dam Aplikasi. Pustaka Pelajar.Yogyakarta.

Sugiyono. 2002. Metode Pelelitian Administrasi. Alfabeta. Bandung. 2007. Statistik Untuk Penelitian. Alfabeta. Bandung.

Suhendra, K. 2008. Manajemen dan Organisasi. Cv. Mandar Maju. Bandung. 
Suwarsono. 2006. Perubahan Sosial dan Pembangunan. PT. Pustaka LP3ES Indonesia. Jakarta.

Suryadi, Soleh. 2009-cetakan kedua. Administrasi Publik dan Otonomi Daerah. Prisma Press. Bandung.

Somantri, Ating. 2006. Aplikasi Statistik Dalam Penelitian. Pustaka Setia. Bandung.

Sopiah. 2008. Perilaku Organisasi. Yogyakarta: C.V. Andi Offset.

Tachan. 2008. Implementasi Kebijakan Publik. TRUENRTH Bandung.

Tangkilisan, Hessel Nogi S. 2003. Kebijakan Publik Untuk Pemimpin Berwawasan Nasional. Balairung. Yogya.

Thoha, Miftah. 1993. Perilaku Organisasi: Konsep Dasar dan Aplikasinya. Jakarta: Rajawali Pers. .2008. Manajemen Kepegawaian di Indonesia. Jakarta : Kencana. 2008. Ilmu Administrasi Publik Kontempoler. Kencana Prenada Media Group. Jakarta.

. 2009. Kepemimpinan dalam Manajemen. PT. Rajagrapindi Persada. Jakarta.

Tjokroamidjojo, Bintoro. 1995. Pengantar Administrasi Pembangunan. PT. Pustaka LP3ES Indonesia. Jakarta.

Wahab, Solichin Abdul. 2004. Analisis Kebijaksanaan Dari Formulasi Ke Implementasi Kebijaksanaan Negara; Edisi Kedua. PT Bumi Aksara.Jakarta.

Wibawa, Samodra. 1994. Kebijakan Publik. Intermedia. Jakarta.

Wibisono, Dermawan. 2006. Manajemen Kinerja. Erlangga. Jakarta.

Widodo. 2007. Manajemen Kinerja:Edisi Kedua. PT. Raja Grafindo Persada. Jakarta. 2009. Analisis Kebijakan Publik.Bayumedia.Malang. 


\section{Dokumen :}

Undang-Undang Nomor 32 Tahun 2004 tentang Otonomi Daerah

Peraturan Daerah Kabupaten Subang Nomor 13 Tahun 2009 Tentang Ketertiban, Kebersihan dan Keindahan.

Surat Nomor 300/224/Sat.Pol.PP/2008 Tentang Perihal Laporan Hasil Operasi Pedagang Kaki Lima (PKL)

Endang.2007. Tesis : Implementasi Kebijakan Pengelolaan Kebersihan Terhadap Kinerja Pegawai Pada Perusahaan Daerah Kebersihan Kota Bandung.

Agustini.2008. Tesis : Implementasi Kebijakan Terhadap Kinerja Pegawai Pada Komisi Pemilihan Umum Kabupaten Bandung. 